\title{
A SURVEY OF MARCHANTIALES FROM MADAGASCAR
}

\section{Catherine Reeb ${ }^{*}$, Lovanomenjanahary Marline ${ }^{2}$, Lucile Rabeau1, Ainazo Andriamanantena ${ }^{3}$, Roger Lala Andriamiarisoa ${ }^{4}$,Hery-Lisy Ranarijaona ${ }^{3}$ \& Tamás Pócs ${ }^{5}$}

\begin{abstract}
${ }^{1}$ Institut de Systématique et Biodiversité, UMR7205, Sorbonne Université, Muséum National d'Histoire Naturelle, CNRS, EPHE. 57 rue Cuvier Case postale 39 France75005 Paris; ${ }^{2}$ Department of Biological Sciences, University of Cape Town, Private Bag X3, 7701 Rondebosch, South Africa; ${ }^{3}$ Université de Mahajanga, Ecole Doctorale Ecosystèmes Naturels; ${ }^{4}$ Missouri Botanical Garden P.O Box 3391101 Antananarivo,

Madagascar; ${ }^{5}$ Department of Botany, Institute of Biology, Eszterházy Károly University, Eger, P.O. Box 43, H-3301;*E-mail: catherine.reeb@mnhn.fr
\end{abstract}

\begin{abstract}
Based on the authors' recent collections and on older herbarium specimens (PC, TAN, EGR), the species of Marchantiidae (Marchantiopsida, Marchantiophyta) of Madagascar are reported with their description based on Malagasy specimens. A distribution map for each taxon is provided. Among the fifteen taxa identified, six are newly recorded for the island, including a new synonymy: Asterella coronata (Steph.) H.A.Mill = Asterella bachmannii (Steph.) S.W. Arnell. Most of Marchantiidae live in xeric areas (Riccia species, Exormotheca pustulosa Mitt.) or in exposed, only temporarily wet stations (Plagiochasma, Asterella). This preliminary study shows the evidence of under-prospection of such areas in Madagascar for bryophytes and the need of taxonomic work to clarify some genera (Riccia, Asterella, Plagiochasma) and to confirm the species hitherto reported.
\end{abstract}

Keywords: Madagascar, liverworts, Marchantiidae, distribution maps

\section{INTRODUCTION}

Madagascar is considered a hotspot of biodiversity and many studies were already conducted upon ferns and angiosperms (Myers et al. 2000, Gautier and Goodman 2009). Bryologists have taken interest in bryophytes sensu lato (mosses, liverworts and hornworts) in Madagascar since the nineteenth century (Bescherelle 1880, 1891; Renauld and Cardot 1895; Dorr 1997, Marline et al. 2012). 
Liverworts were early cited for the island but without references for the complex thalloids (Gottsche et al. 1844, Pearson 1891a, 1891b). Pearson (1893) cited the first thalloid species, Marchantia viridula Lehm., known today as Marchantia globosa Brid. ex Web. and present in Comores Islands (Bischler-Causse 1993) and La Réunion, but without description, specimens or locality information. In Stephani's work (Stephani 1891, 1892, 1893), the only Malagasy thalloid liverwort described is Fimbriaria coronata Steph., a synonym of Asterella coronata (Steph.) H.A.Mill.

The first detailed bryological studies on the Western Indian Ocean Islands focused on mosses (Renauld and Cardot 1895, Renauld 1897, 1909). So did Thériot (1920) who published six volumes on Malagasy mosses including Sphagnum, where only seven liverworts were just reported (M. viridula being always cited as the unique complex thalloid species). Despite historical collections from botanists who gathered plants in Madagascar in the first half of the twentieth century, no general studies on Malagasy liverworts were conducted at that time (Jovet-Ast 1948). Examining new collections and informations from collectors, Jovet-Ast (1948) cited Targionia hypophylla, Riccia fluitans, Fimbriaria wilmsii as present in Madagascar. During the second half of the twentieth century, several studies were conducted on leafy liverworts, new species were described and records were added for Madagascar in a continuous effort, but once again no thalloid liverworts (Tixier 1977, 1984, 1992; Pócs 1995, 2001, 2006; Pócs and Geissler 2002; Pócs and Schäfer-Verwimp 2006; Pócs et al. 2015, Pócs \& Váňa 2015; Vanden Berghen 1981). The most recent check-list of bryophytes of Madagascar published in 2012 reported 1143 species and infraspecific taxa (Marline et al. 2012) including 14 Marchantiidae. Marchantiidae are thalloid liverworts represented all over the world by 372 species (Söderström et al. 2016). They are divided in four orders (Crandall-Stotler et al. 2009): Lunulariales (1-2 species), Marchantiales (340 species and 19 infraspecific taxa), Neohodgsoniales (1 species, restricted to New Zealand) and Sphaerocarpales (32) (Söderström et al. 2016, Wigginton 2009, Marline et al. 2012). According to our study, only Marchantiales occur in Madagascar. 
The thallus of Marchantiales is dichotomously branched, sometimes occurring in rosettes or in isolated lobes forming more or less crowded mats on substratum. They are called "complex thalloid" liverworts, because their thallus is morphologically and functionally stratified. The photosynthetic zone is often restricted to the upper part of the thallus, with an epidermis usually interrupted by air pores, simple or bordered by a complex ring. Scales are often present on the ventral face and their characters are useful for identification. Gametangia of Marchantiales are often born on erect gametangiophores. The sporophytes hang down from female gametangiophores, except in the Ricciaceae family, where gametangia and sporophytes are embedded in the thallus. Marchantiales are often photophilous and they may tolerate high illumination and temperature variations (Bischler-Causse et al. 2005) being often the first colonizers of disturbed and open environments. They colonize rocks and soils, near watercourse, water-falls or seepages or in temporary flooding areas, alternating with long period of drought (Riccia, Targionia).

Thalloid liverworts, like Marchantia are locally called Vahohombato, Vahohontany ("stone tong") or Vohontany ("earth blanket"). They are known to live in shady banks and crushed into mortar with other plants, are used to attract bees in new beehive (Boiteau et al. 1997). They may also be used in the process of huts construction (Boiteau et al. 1997).

This paper presents the description, distribution and ecological data of the species from the sub-class Marchantiales (Marchantiidae, Marchantiopsida, Marchantiophyta) encountered in Madagascar, based on the analysis of herbarium specimens and the authors' recent collections. Six new records are proposed for Madagascar: Asterella bachmannii (Steph) S.W. Arnell., Asterella marginata (Nees) S.W. Arnell, Exormotheca pustulosa Mitt, Riccia congoana Steph, Riccia atropurpurea Sim, Riccia stricta (Lindenb.) Perold, including Asterella coronata (Steph.) Grolle proposed as a new synonym of the African Asterella bachmannii (Steph.) S.W. Arnell. One citation (Riccia perssonii S.A. Kahn) is not retained because no herbarium voucher is associated (Perold 1995b). 


\section{MATERIAL AND METHODS}

Examined material came from specimen collections from field trips in Madagascar and historical collections from herbaria including TAN, PC, MO and EGR, in Madagascar, such as those collected by Decary or Bosser (Dorr 1997). The geographical distribution of the species were assessed from available literature (e.g. Pócs and Geissler 2002) and recent collections.

\section{Recent investigated areas}

Between 2006 and 2014, several sites have been investigated in Madagascar for bryophytes. These areas are mostly located in the low and mid elevation evergreen humid forest (300-1500 m) (Moat and Smith 2007, Goodman 2009), except for the southern Makay Massif belonging to the dry West domain, in the dry decidous forest area (Moat and Smith 2007, Goodman 2009). The sites are presented from North to South, each followed by the province and region in brackets (Figure 1).

The Makirovana Ambanjavala complex (Antsiranana, Sava) was visited in April-May 2010 during a field trip organized by the Missouri Botanical Garden in the context of a conservation project driven by the local populations (M.B.G 2008). The total area covers 5200 ha and is covered by an evergreen low elevation humid forest on a gneiss-granite substratum. The steep elevational gradient is probably the reason of a high diversity (M.B.G 2008).

Namoroka National Park (Mahajanga, Soalala district) is located $50 \mathrm{~km}$ south of Soalala and was visited in October 2016. It is a typical Tsingy massif, characterized by ragged calcareous needles up to 100 meters high and dissected by a karstic network. The vegetation is a seasonal dry forest with a seven-months dry season.

Vohimana New Protected Area (Toamasina, Alaotra-Mangoro region) is located $150 \mathrm{~km}$ east from Antananarivo. The total area of 1635 is covered by a tropical submontane evergreen forest (790$1030 \mathrm{~m}$ ). Bryophyte collections were conducted in July 2006, April 2010 and June-July 2012 together with a fern inventory (Reeb et al. 2012). 


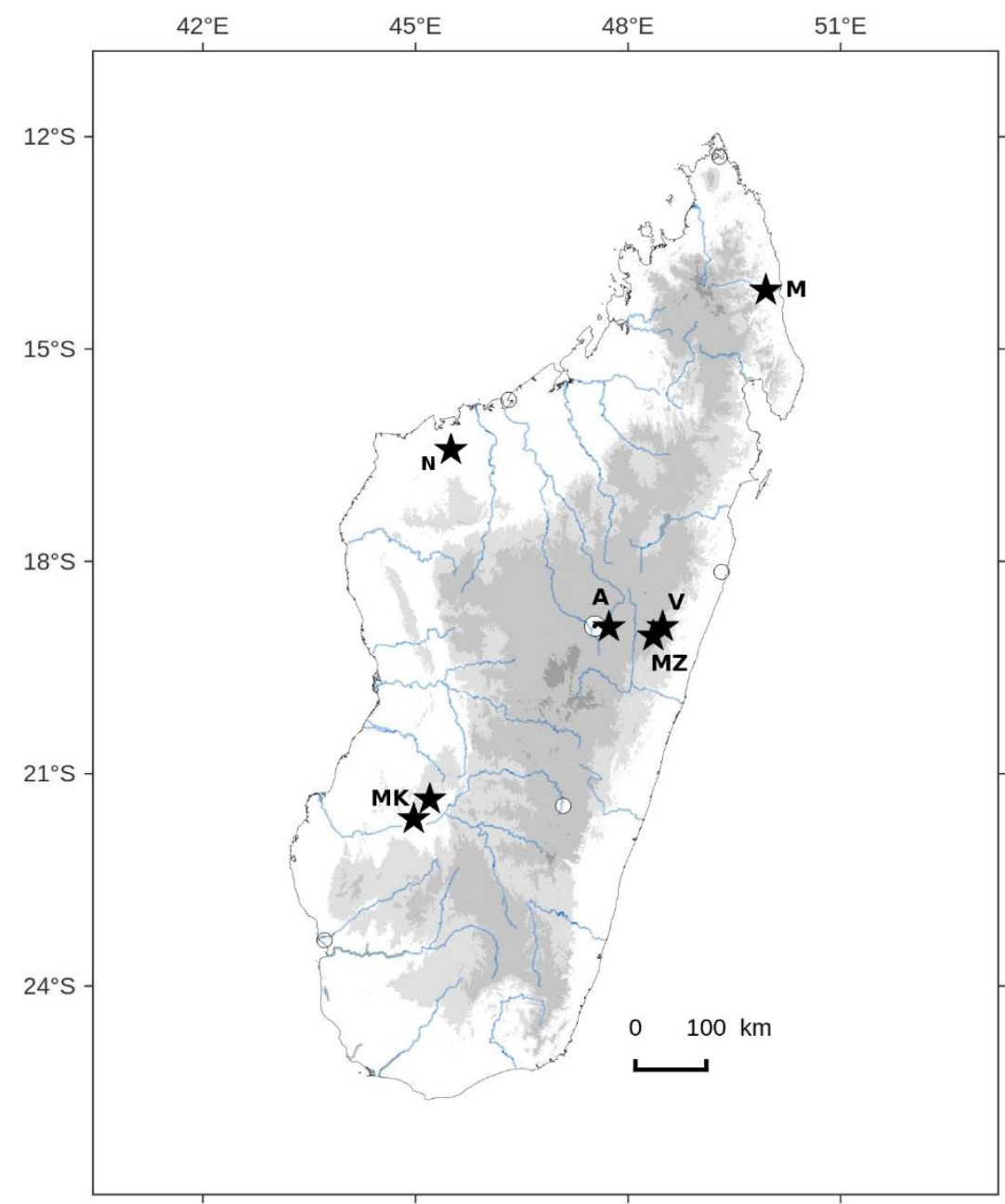

Figure 1. Map of recent missions in Madagascar, from North to South: $M=$ Makirovana, $\mathrm{N}=$ Namoroka, $\mathrm{V}=$ Vohimana, $\mathrm{MZ}$ = Maromizaha, $\mathrm{A}=$ Angavokely, $\mathrm{MK}=$ Makay.

Maromizaha reserve (Toamasina, Alaotra-Mangoro region) is located $30 \mathrm{~km}$ west from Vohimana. It belongs to the same forest complex as Vohimana, 1880 ha covered by a mid-elevation evergreen forest (896-1213 m). The site was visited in July 2012. 
Angavokely forest station (Antananarivo, Analamanga region) is located $36 \mathrm{~km}$ east from Antananarivo, and was visited in February 2011. It is in the central region (Perrier de la Bâthie 1921, Humbert and Cours Darne 1965) with dense evergreen seasonal forest (Faramalala 1995). Angavokely (1300-1787 m) although belongs to the Central High Plateau, is under influences of the eastern humid air. Its high elevation allows the presence of mountain vegetation types on the soil of intrusive gneiss-granitic rocks.

Makay massif (Tuléar, Astimo-Andrefana) was explored for bryophytes during the expedition "Makay Nature" in January 2011 (Wendenbaum 2011), June 2016, July 2017. Makay massif is located in the western part of Madagascar in subarid and dry series (Cornet 1974), west closed dry forest (Faramalala 1995, Moat and Smith 2007). It ranges from forests to impenetrable thickets, to bushland and low scrubs. Trees are largely deciduous apart from riparian elements along the rivers (Moat and Smith 2007). Vegetation is formed by many spiny and small-leaved species and the underlying vegetation is composed of succulents. Extending upon $14000 \mathrm{~km}^{2}$, the Makay is constituted by crumbly sandstone hills notched by deep canyons which give a ruiniform relief, especially eroded by the heavy rains from October to March (near $1000 \mathrm{~mm} /$ month). At the bottom of canyons, narrow gallery forests resist (or not!) to human pressures, especially by the grazing of the zebus and by bush fire. Exposed and sunny riverbanks, bordered by sandstone blocks are convenient for the settling of thalloid liverworts well adapted to dry areas with temporary inundations, such as Riccia or Targionia.

All of the collected specimens were deposited in "Herbier National du Parc Zoologique et Botanique de Tsimbazaza" (TAN, Antananarivo) with duplicates in "Muséum National d'Histoire Naturelle Paris herbarium" (PC, Paris) and at the Missouri Botanical Garden (MO). Species integrated in the distribution maps correspond to all specimens found in PC, TAN and the authors collection, and some specimen identified on the field but not collected: (1) Ambohitantely reserve, visited during the AETFAT field trip in April 2010 and the (2) Montagne d'Ambre, visited in August 2010. 


\section{Studied herbarium specimens}

Marchantiidae specimens from TAN, PC, MO and EGR were studied, including unreferenced and unidentified collections, even if sometimes annotated. Historical specimens were gathered by botanists who wandered across Madagascar collecting mainly angiosperms and ferns: Hildebrandt, the oldest (1879 and 1881), d'Alleizette (1906), Perrier de la Bathie (1921), Waterlot (19131914), Decary (1920-1940), Roger Heim (1934-1935), Bosser (1935-1962), Humbert (1960), Leandri (1952), Boiteau (19661968), Onraedt (1970-1974), Cremers (1973), Tixier (1975-1979). We could also study several untapped documents on Madagascar (specimens, micrographs etc.) gathered by S. Jovet-Ast (1914-2006), a specialist of the Ricciaceae family. Types (isotypes and syntypes) studied from PC herbarium are followed by "!".

\section{Identification, descriptions and distribution maps}

Available literature on the African bryoflora (Arnell 1963, Perold 1999, Chuah-Petiot 2003, Jones 2004) and specific studies on Marchantiidae (Jovet-Ast 1955, Bischler-Causse 1978, Jovet-Ast 1989, Bischler-Causse 1993, Perold 1995a, b, c; Bischler-Causse et al. 2005, Long 2006, Fischer 2016) and herbarium specimens (from PC) were used as references for species identification.

For each species a short description of specimens is associated to a distribution map. For the complete description, we refer to the literature on African liverworts mentioned above. The measurements are given for the Malagasy specimens; if larger or smaller dimensions are found in the literature, they are reported in brackets. The barcode of PC specimens follows the abbreviation, when available. Spelling corrections of geographical names from original labels or additional geographic information may be added between squared brackets [ ]. When complete, dates were homogenized in "dd/mm/yyyy" format, in other cases the date from the original label was kept.

Distribution maps represent the known localities from all the studied specimens, and the comments about distribution are based on these maps. 


\section{RESULTS}

\section{Key of Malagasy Marchantiidae}

1a Thalli large (mostly $>1 \mathrm{~cm}$ width), dark to yellowish green, translucent when humid, margins hirsute, ventral face with parallel and often curved lines of white rhizoids; air pores and air chambers absent; male receptacle on very short stalk (seems sessile). Dumortiera hirsuta

1b Thalli small to large, margins not hirsute, ventral face without parallel and curved lines of white rhizoids; air pores (see cross section) present; gametangia stalked or embedded.......................... 2a Dorsal epidermis in form of conical protuberances materializing the roof of air chambers, with a pore at apex of each protuberance

Exormotheca pustulosa

2b No dorsal conical protuberances, even if air chambers could be slightly elevated (see in cross section).....

3a Thalli small to medium, in partial or complete rosette or fan-like, air chambers in vertical channels or polygonal to rounded, sporophytes embedded .4 3b Thalli medium to large, not in rosette but in elongated lobe with dichotomous ramification; air pores compound or simple .10 4a Thalli iridescent, air chambers rounded to polygonal, in one layer; male gametangium marginal and disk shaped, sporophyte in apical cavities of the thallus, elaters and oil-bodies present. Cyathodium cavernarum

4b Thalli not iridescent; air chambers in vertical channels or large, polygonal in several layers (2-5), gametangia and sporophyte embedded in thallus but not apical; elaters and oil-bodies absent. (Riccia) 5

5a Thalli less than $1 \mathrm{~mm}$ wide, cilia marginal and mixed with papilla on dorsal face ..R. atromarginata var.jovet-astii

$\mathbf{5 b}$ No cilia on the thalli

6a Thalli strap like, with rounded or polygonal air chambers, often aquatic or semi-aquatic, sporophyte bulging ventrally 7

6b Thalli not strap like, air chambers in vertically parallel channels, sporophyte not bulging or bulging dorsally..... 8 7a Apex rounded without groove often thickened into a bulge; 
spores with 5-6 complete alveoli on distal face.

R. stricta

7b Narrow groove visible in apical part, apex narrow and emarginate, not thickened into a bulge; spores with 8-10 complete alveoli on distal face

R. cf. purpurascens

8a Thalli spongiose, becoming lacunose with age. No ventral scales or evanescent ones

R. cavernosa

8b Thalli not spongiose, at least half of each ventral scale black coloured

9a Large species, lobes up to $5 \mathrm{~mm}$ wide, green to blue-green, margin scallopped by conspicuous black ventral scales.

R. congoana

9b Medium size species, glaucous green, ventral scales purple-black in basal part with a conspicuous white upper margin, clasping together when dry, forming two typical white lips

R. atropurpurea

10a Thalli rolled around itself when dry showing the completely purple-black and shiny ventral face; pores visible by naked eyes when wet; sporophyte apically and ventrally embedded in a mussel like black, clapping involucre

Targionia hypophylla

10b Thalli not showing a complete purple-black shiny ventral face; pores visible by naked eyes or not when wet; archegoniophore stalked and sporophyte hanging below archegoniophore lobes

11a Pores barrel shape, air chambers in one layer, filled with chlorophyllose filaments; gemma cups present; antheridiophores and archegoniophores raised on a long stalk

(Marchantia) 12

11b Pores simple, air chambers empty in one to several layers; no gemma cups

13

12a Thalli 5-10 mm wide without dark median line; pores of 70$125(-200) \mu \mathrm{m}$ diameter bordered by 7-8 rings of cells; antheridiophores of 10-14 mm diameter.......Marchantia pappeana 12b Thalli 3-6(-7.5) mm wide generally with a conspicuous dark median line; pores $40-70(-100) \mu \mathrm{m}$ diameter bordered by $5-6(-7)$ rings of cells; antheridiophores of 3-5(-8) $\mathrm{mm}$ diameter Marchanta debilis

13a Archegoniophore arising apically, on stalk, female receptacle with rhizoid furrows, pseudoperianth present and splitting longitudinally into 8-16 slender segments. (Asterella) 14 
13b Archegoniophore not apically arising, on stalk, female receptacle without rhizoid furrows, pseudoperianth absent..............Plagiochasma microcephalum var. microcephalum 14a Carpocephalum covered with papillae more than $200 \mu \mathrm{m}$ high, generally two yellow pseudoperianths, ventral scales generally with one appendage Asterella bachmanii 14b Carpocephalum with low papillae and generally 4 pseudoperianths, 1-2 appendages. Asterella marginata

The species are presented in the alphabetical order within family. Synonyms and types are given by date of citation. Specimens are presented by geographic range, using the six official Malagasy provinces. Taxa recorded as new for Madagascar are followed by a “*”. Types examined are followed by “!”.

\section{AYTONIACEAE}

In older publications, the family name is often written as "Aitoniaceae"; the genus Aytonia, is also found spelled by the variant: (1) Aytonia J.R. \& G. Forst, Char. Gen. Pl.: 147 (1776); Lindb.: 291 (1898); Schiffn.: 30 (1983). Type: A. rupestris, (2) Aitonia J.R. \& G. Forst, Comm. Soc. Reg. Göttingen 9: 46, 73 (1787), orth. var.

But as "Aitoniaceae" is an Angiosperm family (Aitoniaceae Harv. \& Sond.), endemic of South-Africa, the correct name for this liverwort family is "Aytoniaceae" and Aytonia for the genus, basionym of Plagiochasma.

Asterella bachmannii* (Steph.) S.W. Arnell. Hepat. S. Africa 62. 1963. Basionym: Fimbraria bachmannii Steph. Hedwigia 33(1): 7 (1894). Type: SOUTH-AFRICA, Transvaal, s.d., MacLea s.n., exsiccata Rehman 3 (PC-PC 0736583! JE) (spelling var. Fimbriaria). Synonym: Asterella coronata (Steph.) H.A.Mill., Phytologia 47: 319 (1981) syn. nov. Basionym: Fimbraria coronata Steph. Spec. Hep. 6: 12 (1917). Type: MADAGASCAR, Vallée de la Mandraka, 15 août 1906, d'Alleizette 60 (PC-PC10155!), d'Alleizette 125 (PC-PC10156!). Thallus thick, clear and shiny green, with purple margin, only slightly undulated, 13-20 mm long and 2,5-4 mm wide. Air 
chambers in several layers. Pores surrounded by 2 rings of 6-8 cells. Ventral scales in two ventral rows, triangular, pink, 1500$1650 \mu \mathrm{m}$ long, 500-600 $\mu \mathrm{m}$ wide; appendage pink, lanceolate constricted at the basis, apex acute, 800-850 $\mu \mathrm{m}$ long, 120-160 $\mu \mathrm{m}$ large. Dioïcous. Antheridia in sessile cushions near apex of main branches, sometimes on lateral innovations. Carpocephalum papillose, with two yellow pseudoperianths. Spores yellow, translucent with crenulate margin, 90-120 $\mu$ m diameter and with 8 alveoli in the proximal face.

Distribution: Humid to sub-humid central zone, above $400 \mathrm{~m}$ (Figure 73). Occurs also in Africa (South-Africa, Zimbabwe, Malawi).

Ecology: on rocks or humid banks along rivers and open areas.

Specimens examined: ANTANANARIVO, Tsanisana [Nanisana], 01/1906, d'Alleizette (PC-PC0049107); bord de la Manankaza, [Manankazo] $130 \mathrm{~km}$ de la route de Majunga, Bosser, (PC); 04/1904, Waterlot 138 (PC-PC0738492); Ambohimanga, 06/1914, Waterlot 169 (PC-PC0738503), Waterlot 167 (PC-PC0738501); Andramasina, 30 km SSE d'Antananarivo, Leandri 3089 (PC); Andramasina, 1350 m, 25/05/1976, Tixier H10020 (PC-PC0738874); Befotaka, Pic de Karafanga [Farafangana], 06/08/1926, Decary s.n. (PCPC0738499); Vallée de la Mandraka, 1200 m, 24/02/1974, Onraedt $74 M 2003$ (PC-PC0738867); Vallée de la Mandraka, 23/10/2015, Reeb \& Solofo CR15M91; Ambatoloama [Ambatoloana], PK64 route de Tamatave [Toamasina], 1250 m 18/05/1976, Tixier H10019 (PCPC0738873); MAHAJANGA, Bealanana, Mangindrano, forêt de moyenne d'altitude d'Antsihavo à $7 \mathrm{~km}$ de la commune rurale de

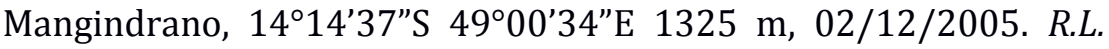
Andriamiarisoa 660 (MO); FIANARANTSOA, Ranomafana National Park, Namorona river, alt 1080-1150 m, 26/07/2004, S. \& T. Pócs 04126/AR (EGR, MO, PC-PC0738869, TAN); Ranomafana National Park, 3km from Vohiparara village, 24/07/2004, T. Pócs \& $R$. Ranaivojaona 04121/E (EGR, MO, PC-PC0738870, TAN); Isalo National Park Malaso circuit on a sandstone block, 28/05/2016, C. Reeb, L. Rabeau CR16M159 (PC, M0).

Observation of isotypes of $A$. coronata and comparison with specimens and description of $A$. bachmannii led to the conclusion that these species are identical (vegetative characters, spore 
characters and dimensions). We propose the synonymy of $A$. coronata (Steph.) Grolle with A. bachmannii (Steph.) S.W. Arnell which is the accepted name of the species according art. 11 (priority rule ICN).

Asterella marginata* (Nees.) S.W.Arnell Hepaticae of South Africa 62. 1963. Basionym: Fimbraria marginata Nees. Hortae Physicae Berolinenses 44. 1820 Type: Capite b. spei, crescit iuxta viam in monte Leuwenstaart ad terram, leg. Bergius (BM) (spelling var. Fimbriaria). Thallus thick, undulate with purple margins (Figure 2), $20-23 \mathrm{~mm}$ long and 2,5-5 mm wide, sometimes with ventral innovations, some lobes cordate with overlapping apex after notches. Air chambers in several layers in cross section. Pores slightly elevated, surrounded by 2 rings of 5-6(-9) cells. Ventral scales in two lateral rows, triangular, red to purple, 1000-1500 $\mu \mathrm{m}$ long and 400-450 $\mu \mathrm{m}$ wide; appendages 1-2, lanceolate, pink, 450$700(-1200) \mu \mathrm{m}$ long, $120-150 \mu \mathrm{m}$ wide, not or slightly constricted at basis, few small papilla along the margin, apex acute with a single apical cell. Dioicous? Antheridia in sessile cushions on ventrolateral innovations or at base of main branches. Carpocephalum rounded when young and slightly papillose due to air chambers, umbonate when mature with 3-4 (mostly 4) slanted pseudoperianths, palea up to $2 \mathrm{~mm}$. Spores yellow-orange with a crenate margin, of 114-133(-140) $\mu$ m diameter with 6 clear alveoli on the distal face and a net triradiate mark on the proximal face.

Distribution: Humid to sub-humid central zone, elevation more than $400 \mathrm{~m}$ (Figure 73). Occurs in South-Africa.

Ecology: on rocks or humid banks along rivers or trails.

Specimens examined: ANTANANARIVO, Entre Antananarivo et Befato [Betafo], juin 1894, Caussèque 345 (PC-PC0738875); Ambohimanga, 27/03/1921, Decary s.n. (PC-PC0738500, PC0738502, PC0738495, PC0738496, PC0738497); Imerina, montagne de Behenjy, 11/05/1921, Decary s.n. (PC-PC0738498); Pk 28 route du Sud, 03/1956, Bosser 9207 (PC-PC0738506), 09/1960, Bosser14586 (PC-PC0738506); Iharanandriana, Pk 39 route du Sud, 05/1962, Bosser 15898 (PC-PC0738505); Nanisana, Alleizette, (PC); Andramasina, $30 \mathrm{~km}$ SSE d'Antananarivo, 1400-1500 m 17 février 
1960, Leandri 3101bis (PC); Analabe, près d'Ambositra, Onraedt $70 M 359$ (PC); MAHAJANGA, Bealanana, Mangindrano, forêt de Bemafo, Ambohimirahavavay. Forêt dense humide, sempervirente. 29/11/2005 R.L. Andriamiarisoa 621 (MO). ToAmASINA, Zahamena, 1H30 de Ranofotsy along river Ankotokotroka [Ankotrokotroka] 1169 m, 17³6'39"S 4840'21"E, Reeb \& Andriamanantena CR13Z65 (PC-PC0738872, TAN).

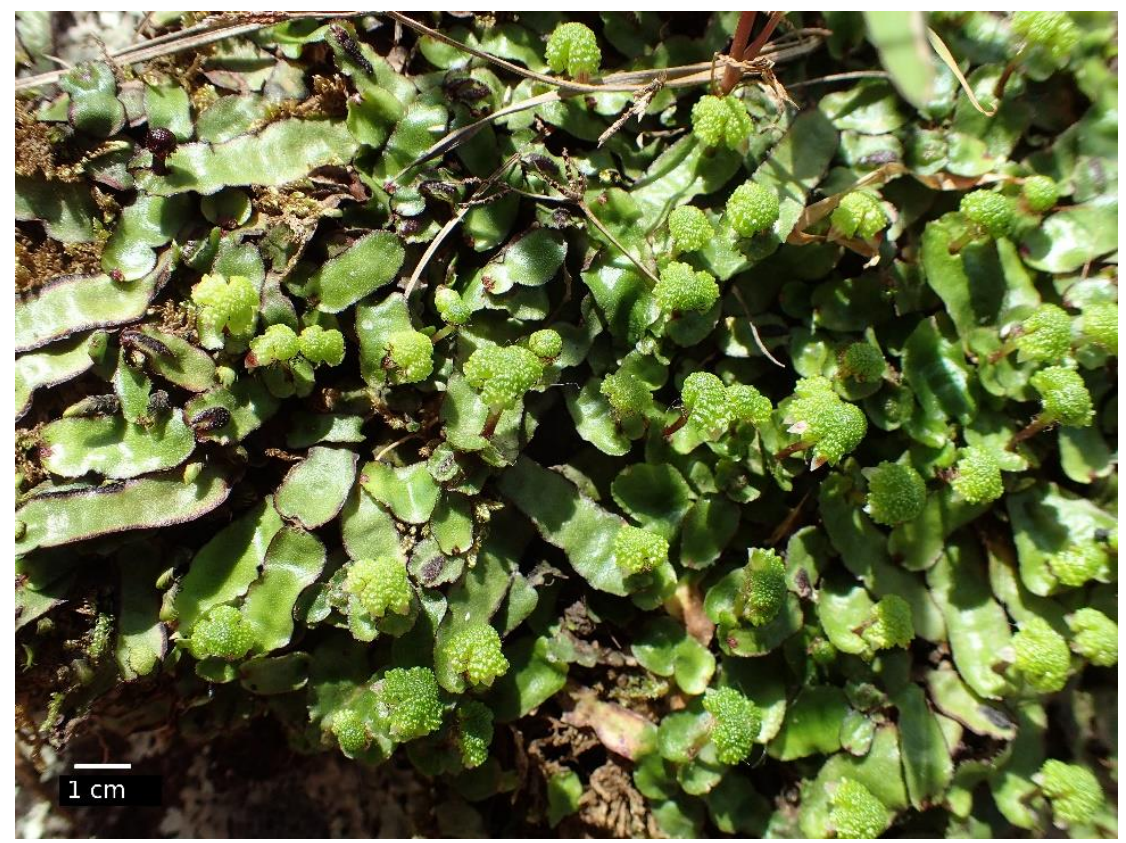

Figure 2. Asterella marginata, near Fianaransoa. Scale bar $1 \mathrm{~cm}$.

Excluded species: Asterella wilmsii (Steph.) S.W.Arnell Asterella bachmannii and Asterella marginata differ mostly by (1) larger dimensions for A. marginata, (2) number of pseudoperianths, regularly 2 for $A$. bachmannii, 4 for $A$. marginata and (3) the appendages, generally one constricted at basis in A. bachmannii and often 2 appendages not constricted at basis in A. marginata (this character is sometimes difficult to evaluate because of its variability within a single thallus). 
A. wilmsii and the endemic species Asterella coronata (Steph.) Grolle are cited in Madagascar checklist (Wigginton 2009, Marline et al. 2012).

A. bachmannii and $A$. marginata can be easily confused (Vanden Berghen 1972, Perold 1999), but we found also that $A$. wilmsii is very close to $A$. marginata. This last species was retained for Malagasy specimens based on the ventral scales and appendages (2 not constricted, only one in A. wilmsii), carpocephalum characters and spore diameter (smaller than in A. wilmsii according Perold's description).

Plagiochasma microcephalum (Steph.) Steph. var. microcephalum. Bull. Herb. Boissier 6: 781, 1898. Basionym: Aytonia microcephala Steph. Botanisch Jaarboek 20: 301, 1895. Type: TANZANIA, Usambara, Holst C.H.E 392 (G-G00121196).

Thallus dark green when dry and yellow-green and dull with purple margin when re-hydrated, 10-25 mm long and 4-5 mm large. Pores simple, slightly elevated, surrounded by 2 rings of 5-7 cells. In cross section, epidermal pore simple and slightly elevated. Ventral scales in two rows, purple, with external hyaline cells and central purple cells, 720-1550 $\mu \mathrm{m}$ long, up to $1000 \mu \mathrm{m}$ large; appendages $1(-2)$, rounded to triangular, mostly apiculate, of different sizes, generally slightly constricted or folded at basis, $5-7(-8)$ rows of cells in the width of the appendage, some external cells oblique and internal cells elongated trapezoidal to rectangular; few cells with persistent oil-bodies in the body of scale and appendage. Monoicous. Antheridial receptacles on the median part of the thallus. Archegoniophores rounded and pedunculate. Spores not seen. No asexual reproduction structures.

Distribution: to date, only found in Madagascar at elevation > $1000 \mathrm{~m}$ (Figure 74). P. microcephalum occurs from East-Africa to South-Africa and from Yemen to South-West India (Perold 1995a, Bischler 1978).

Ecology: it grows in patches on shaded and temporary hydrated rocks, naked or covered by compact layer of humus, even if may support a long dry season.

Bischler (1978) identified specimens of Onraedt 70m158 and Decary 
s.n. This species is recognized by the characters of appendages especially by the presence of 1-2 rows of external cells in which oblique rectangular cells are always found. This is the main difference we found when compared with Plagiochasma beccarianum Steph., which seems to be close, when sterile. The shape of the antheridial receptacle differentiates also Plagiochasma species, but this character was not very clear on old collections. The examined Malagasy specimens have always apiculate appendages, a rare character according to Bischler (1978), but with a high variability in shape.

Specimens examined: ANTANANARIVO, Ambohimanga, $20 \mathrm{~km}$ d'Antananarivo, alt $1000 \mathrm{~m}, 06 / 01 / 1970$, Onraedt $70 M 158$ (PCPC0738865); Ambohimanga, 27/03/1921, Decary s.n. (PCPC0738866); Andramasina, fév. 1958, Decoings BD3069 (TAN); Andramasina 30 km SSE d'Antananarivo, 1400-1500 m 17/02/1960 Leandri 3101bis (PC). MAHAJANGA, bord de la Manankaza [Manankazo], $130 \mathrm{~km}$ de la route de Majunga [Mahajanga], 22/11/1951, Bosser s.n.

New fertile collections of Aytoniaceae are much needed in order to confirm the identity of these three species. Asterella has been studied both morphologically and molecularly with several sequences available on GenBank (Long 2001, 2005, 2006). Inclusion of Malagasy specimens in a molecular approach will be useful to delineate these species. In an upcoming study, DNA barcoding identification will be performed for Malagasy species. 


\section{CYATHODIACEAE}

Cyathodium cavernarum Kunze, Nov. Stirp. Pug. 6: 18, 1834 (Lehmann 1834). Type: CUBA s. loc. 1824 Poeppig s.n. (holotype W, isotype, S. Synonym: Cyathodium africanum Mitt., J. Proc. Linn. Soc. London 22: 327 (1887). Type: TANZANIA, Usagara Mountains, J. Hanningtion s.n. (holotype, K).

Cyathodium mexicanum Steph. Rev. Bryol. 36: 139 (1909). Cyathodium barodae Chavan, Bryologist 11: 57 (1937). Type: INDIA Baroda state, Baroda, 1934-1935 Chavan s.n.

Thallus dichotomous, very thin, no mid-rib, rounded apex and lobes overlapping, iridescent in fresh (Figures 3, 4) and in dry herbarium specimens (Figures 5, 7), 1-3 mm wide. Air chambers slightly forming a network, in one row in cross section (Figure 6). Pores bordered by 2-3 circles of hyaline cells. Ventral scales inconspicuous or absent. Monoïcous. (Antheridia not seen): antheridal receptacle lateral terminal, cushion shaped or diskshaped. Archegonia and capsules protected by an involucre globose to elliptic, without hairs but bearing few to numerous and irregular rhizoids (Figures 8, 9); mouth emarginate and flaring after a small narrowing border formed by a few rows of thickened cells appearing orange-brown (Figure 8). Spores brown 45-50 (-83) $\mu \mathrm{m}$ with spinae $2-3(-4) \mu \mathrm{m}$ long.

Distribution: found in Réserve speciale of Manongarivo and in the Namoroka tsingys (Figure 75). Occurs in India, Java, Africa and America.

Ecology: in Madagascar at the entrance of caves on naked and compact soils in a shady ambiance.

The specimens show all the characters of the species (Mitten 1887, Srivastava and Dixit 1996, Jones 1952, 2004). The involucre of the capsule is especially crowded with rhizoids, but without white erect whitish bristles typical for Cyathodium aureonitens Griff. 

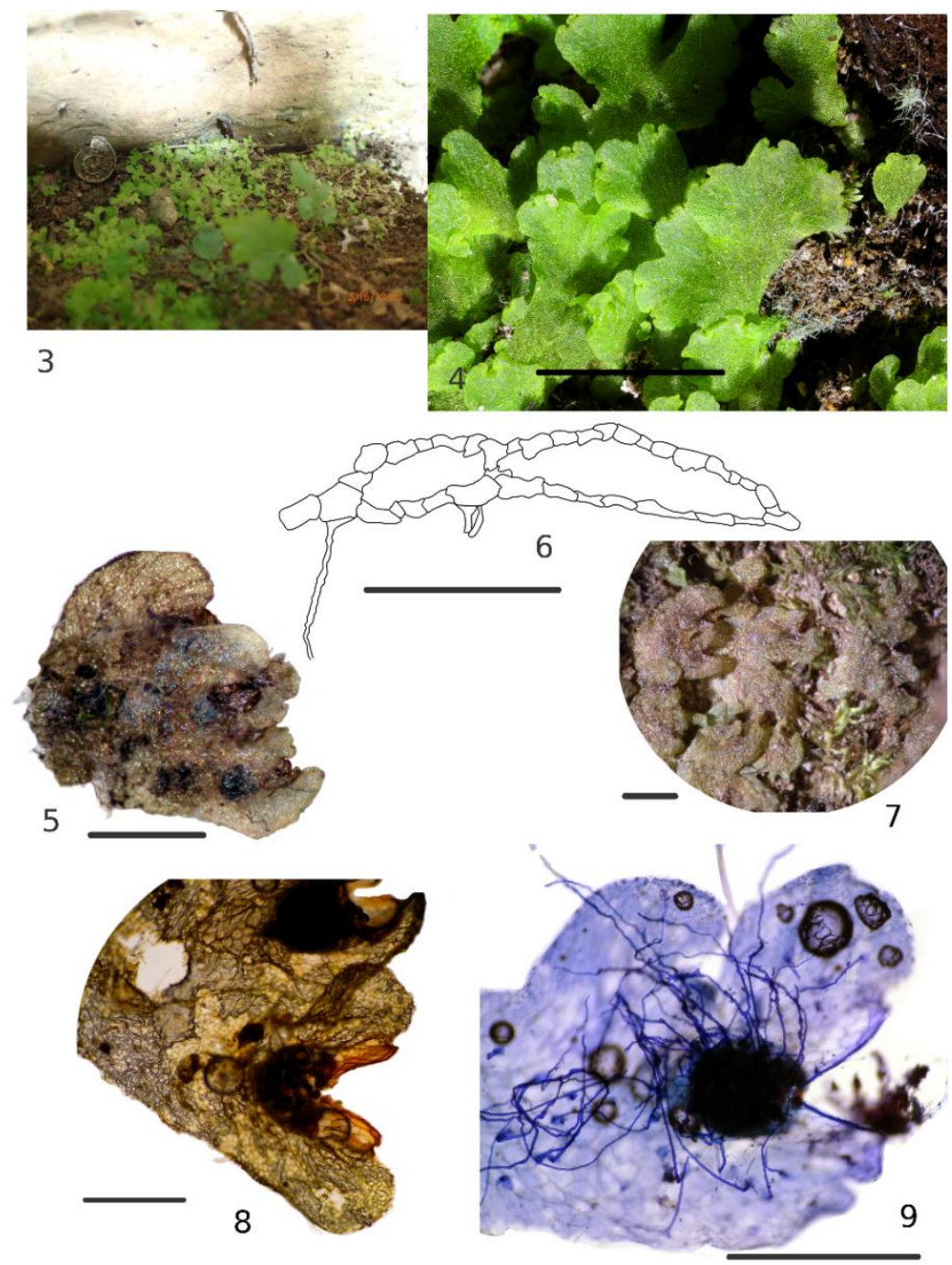

Figures 3-9. Cyathodium cavernarum Kunze. (3) General view on the field at the entrance of a cave, in Namoroka tsingy. (4) Close view of iridescent thalli. Photo: Gernordt Kunz. (5) Iridescent thallus in collection. (6) Cross section: only one layer of air chambers, and one cell thick epidermis. (7) Ventral face. (8) Details of the involucre with thickened cells at the opening of the mouth. (9) Bleach and blue treatment highlights rhizoids on the involucre (not spiny hairs like in C. aureonitens (Griff.) Mitt.), 9855/C. Scale bar $1 \mathrm{~mm}$. 
This tiny species cannot be missed because of its iridescence that is due to the position of the chloroplasts in the lens-shaped cells of the upper epidermis. This allows light to reflect and to refract through cells and air-chambers (Duckett and Ligrone 2006). Traditionally placed in the Targoniaceae family (Grolle 1995), the placement of the genus Cyathodium in the Cyathodiaceae family was confirmed by molecular and phylogenetic analysis (BoisselierDubayle et al. 2002; Duckett and Ligrone 2006).

Mitten (1887) gave a very short and incomplete description of $C$. africanum and claimed that it was very similar to the Indian Cyathodium aureonitens Griff., but he did not put the two names in synonymy. Nevertheless, Griffith (1849) draw a typical capsule with whitish bristles (p. 354) not present in C. africanum. Its seems that a great confusion remained over time between $C$. cavernarum $(=C$. africanum) and C. aureonitens (Jones 1952, see Srivastava and Dixit 1996 p. 155), but Jones (1952) undoubtedly reported the two species in Africa.

In the more recent literature (Jones 1952, Jovet-Ast 1970, Vital 1974, Srivastava and Dixit 1996, Jones 2004, Bischler-Causse et al. 2005) C. africanum descriptions or illustrations are similar to those of C. cavernarum (Lehman 1834, Chavan 1937 under C. barodae) and Srivastava and Dixit (1996) proposed their synonymy in their revision of the genus. Vital (1974) and Jones (2004) observed the capsule of $C$. cavernarum crowded with rhizoids, like in Malagasy specimens (could they have been confused with the spiny whitish bristles observed in $C$. aureonitens?). We also examined all the African specimens from PC, reviewed by N. Salazar as C. cavernarum (Bischler-Causse et al. 2005) but primary identified as C. africanum. Jones (2004) followed the synonymy given by Srivastava and Dixit (1996) and considered C. africanum as a synonym of Cyathodium cavernarum Kunze. But Wigginton (2009) reinstated C. africanum waiting for clarification of the status of the species. C. africanum is also cited in the checklist of Madagascar (Marline et al. 2012). As in Söderström et al. (2016), only C. cavernarum is retained, we considered that it is the species found in Madagascar.

Specimens examined: ANTSIRANANA, réserve de Manongarivo, elev. 90-150 m, 1354.9'S 48²7.8'E 23/07/1998, T. Pócs \& A. Szabó 
\& R. Ranaivojaona 9855/B (EGR). MAHAJANGA, Tsingy de Namoroka on naked soil, very shady base of vertical walls in a cave opening $16^{\circ} 32^{\prime} 30 \mathrm{~S} 45^{\circ} 18^{\prime} 39.9 \mathrm{E}$ Reeb CR16M345.

\section{DUMORTIERACEAE}

Dumortiera hirsuta (Sw.) Nees, Nova Acta Academiae Caesareae Leopoldino-Carolinae Germanicae Naturae Curiosorum XII: 410, 1824. Basionym: Marchantia hirsuta Sw.: Nova Genera et Species Plantarum seu Prodromus 145, 1788. Type: JAMAICA, leg. Swartz s.n. (holotype S-B36649; isotype MW-Hb. Hoffm. 8497, UPS-BOT: B039582). Thallus striped, rigid and fleshy, to $100 \mathrm{~mm}$ long and 20 $\mathrm{mm}$ wide, yellow-green to dark green, translucent to obscure (Figures 10, 11, 15) with dichotomous branching and apical reiterations, often preceded by a constriction of the thallus (Figure 11), dorsal face smooth, ventral face with an obvious central nerve, sometimes pink with long shiny rhizoids. Pores invisible on dorsal epiderm, absent also in cross section. Ventral scales discrete, whitish, their insertion forming a succession of incurved and parallel lines on each side of the central nerve (Figure 12). Dioicous or monoicous? Antheridiophores in disc shape receptacle, sessile or with a very short stalk. Archegoniophores often seen sessile with typical bristles on margin (Figures 13, 14,15) before the stalk grows. Spores not seen. No gemmae or propagules.

Distribution: humid and sub-humid forests from Center to North (Montagne d'Ambre) (Figure 74). D. hirsuta has an oceanic subcosmopolitan distribution (Perold 1993, Bischler 1998).

Ecology: in shady humid environment. 

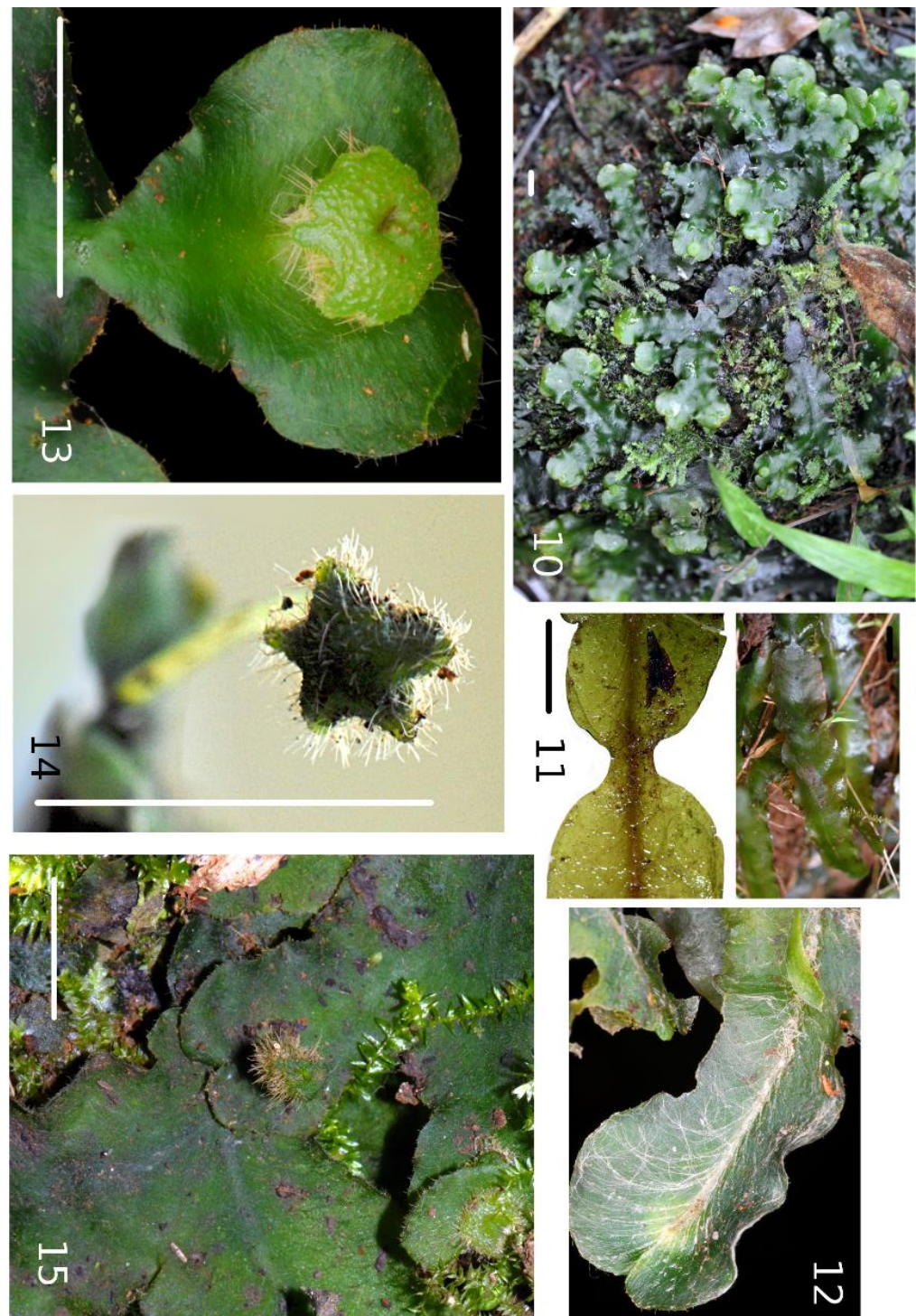

Figures 10-15. Dumortiera hirsuta (Sw.) Nees. (10) Specimen along a streambed with typical undulate margins. Zahamena, January 2014. (11) Branch showing constriction at the base. Réserve de Vohimana, 2010. (12) White ventral scales in parallel curved lines and central nerve. Vohimana, April 2010. Photo: Ehoarn Bidault. (13) (14) Archegoniophores. Vohimana, April 2010. (15) Mature archegoniophore on a mat thallus, Montagne d'Ambre, August 2010. Scale bar $1 \mathrm{~cm}$. 
Most specimens are fertile. The species shows some variability with: (1) rigid, olive green thallus with long branches, especially in the Vohimana reserve where it is found creeping among Poaceae at the bottom of a waterfall or (2) deep green, more flexible thallus is observed in shady stations, on rocks, always around waterfalls or permanent water seepages. We suspect that this species could be more widespread in Madagascar, in the humid to sub-humid areas, especially near riverine forest, streams and waterfalls.

D. hirsuta was cited for the first time for Madagascar by Marline et al. (2012), after the Bryolat field trip in the Marojejy National Park in 2009. It seems to be present in each humid forest we visited. We found also numerous specimens of $D$. hirsuta in the historical collections. D. hirsuta was known for Mauritius since the nineteenth century (Gottsche et al. 1844), and this is an example of a thalloid liverwort being under-studied in Madagascar, unidentified plants being kept in herbarium since a long time.

Specimen examined: ANTANANARIVO, Anjozorobe 01/02/1959, Bosser 12648, (TAN); Cascade d'Ankitsoko, 24/09/1934, Heim $1367 a$ (PC-PC0738507); s.l., 1934-1935, Heim 1101a (PCPC0738518); Vallée de la Mandraka, 23/10/2015, Reeb \& Solofo CR15M94; ANTSIRANANA, Marojejy National Park, elev. $690 \mathrm{~m}$,

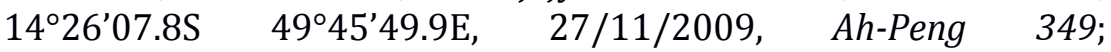
Anjangoveratra, forêt du Makirovana, elev. $508 \mathrm{~m}, 1^{\circ} 10^{\prime} 17.4 \mathrm{~S}$ 4957’07.5E, 07/05/2010, Reeb CR302, (TAN, PC-PC0738892); Massif du Makirovana, 22/08/2010, Reeb CR322, (TAN, PC-PC). FIANARANTSOA, Sud Betsileo, Ankafina [=Tsarafady], März 1881, Hildebrandt s.n. (PC-PC0738893); Ihosy, près de Ranotsara, 01/12/1963, Bosser 17768 (TAN, PC); Parc National de Ranomafana, near Ambodiamontana, valley Namorona, 25/07/2004, S. \& T. Pócs 04118/J (EGR); TOAMASINA, Ambavaniasy, réserve de Vohimana, elev. $849 \mathrm{~m}, \quad 18^{\circ} 55^{\prime} 43.6 \mathrm{~S} \quad 48^{\circ} 29^{\prime} 56.6 \mathrm{E}, 15 / 04 / 2010$, Reeb, Andriamanantena \& Bidault CRAE93, (PC-PC0738888, TAN); Ambavaniasy, réserve de Vohimana elev. $789 \mathrm{~m}, 18^{\circ} 55^{\prime} 12.7 \mathrm{~S}$ 48³0'57.9E, 13/04/2010, Reeb, Andriamanantena \& Bidault CRAE7, (TAN, PC-PC0738889); Zahamena, 1 h30 de Ranofotsy, le long de l'Ankotrokotroka, 1169m, 17³6'39.0S 4840'21E, 04/01/2014, Reeb \& Andriamanantena CR13Z93 (PC-PC0768890), CR13Z85 (PC- 
PC0768891). It was also observed in Ambohitantely forest and in Montagne d'Ambre National Park, above $400 \mathrm{~m}$.

\section{EXORMOTHECACEAE}

Exormotheca pustulosa* Mitt. Nat. Hist. Azores or Western Islands 326, 1870 Type: MADEIRA, Pico de Barcellos, leg. Johnson (holotype, NY). Synonym: Exormotheca africana Steph. Spec. Hep. 6: 18, 1917. Thallus compact and bifurcate in two ligulate lobes, small, $<1 \mathrm{~cm}$ long, (Figure 16), dorsal surface irregular due to air chamber elevation with pores, margin recurved when dry, scales covering the dorsal margin. Air chambers conspicuous, elevated up to $320 \mu \mathrm{m}$ in cross section (Figure 17). Ventral scales conspicuous, purple-black, covering flanks (Figure 18), exceeding the margin, especially near apical zone; scales not present on the central zone of the ventral face. Monoiocous or dioicous? Antheridia sunken in the thallus, prolongated by a protruding neck, emerging between air chambers and around the same hight. Archegoniophores in a central cushion. Spores not seen.

Distribution: one collection in South Central area. Occurs in the Atlantic islands (St. Helena, Madeira, Azores), Mediterranean areas (Portugal, South of France, Italy, Spain), Arab Peninsula, widespread in tropical and South Africa, Comores and La Réunion (Bischler, 1976, Perold 1999) and was found finally in Mexico (Bischler et al. 2005).

This is the first record of the species for Madagascar. It is not surprising to find it in the semi-arid region of the island (Figure 75). New collections are needed in order to enlarge its known distribution and ecology in the country.

The unique specimen of E. pustulosa is more than fifty years old, and it was not easy to get clear and clean cross sections. However, this noteworthy liverwort is easy to recognize to the naked eyes by (1) the conically juxtaposed air chambers, (2) the lateral scales, and (3) the organization of reproductive structures.

Specimen examined: FIANARANTSOA, Ihosy, sur terre humide, Janv. 1962, Bosser 15376 (PC-PC0715993, TAN). 


\section{MARCHANTIACEAE}

Marchantia debilis K.I.Goebel, Organographie der Pflanzen. Ed. 2 2(1): 901.1915

Type: CAMEROON, Urwaldgebiet von Bipindi, Zenker, Flora von Kamerun exs. 1339 (BM!, BR, E, F, G!, GOET, M, S, isotypes).

Synonym: M. chevalieri Steph. ex Bonner, Candollea14: 103 (1953). Type: IVORY COAST, Haute Côte d'Ivoire, pays Dijola, environs de Ona, 4-1909, Chevalier s.n. (G, PC). Thallus dichotomous, elongated, bright green with a narrow median black line, often interrupted, margin recurved on fresh specimen, hyaline sometimes coloured with purple, entire, undulate to crisped; thallus small to medium sized 20-30 mm long, each axis 3-6(-7.5) mm wide (Figures 19, 20). Air pores visible, $40-70(-100) \mu \mathrm{m}$ diameter bordered by $5-6(-7)$ rings of cells, 2-3 above epidermis, and 2-3 projecting into the cavity (Figure 24). Ventral scales in 4 rows, not extending more than 30 $50 \%$ of thallus width, purple at least in median portion, 1210-1950 $\mu \mathrm{m}$ long, 830-910 $\mu \mathrm{m}$ wide, oil cells scattered; appendage ovate to orbicular, purple, (300-) 450-550 $\mu \mathrm{m}$ long, bordered by unicellular teeth, oil-bodies absent (Figure 25). Cupules shorly ciliate, cilia 1-2 cells long (Figures 21, 22). Dioicous. Antheridiophore at apex of axis, stalk 13-15 mm long, with a single band of air cavities, receptacle 3-5(-8) $\mathrm{mm}$ diameter with (4-) 7-10 rays generally asymmetric. Archegoniophore at apex of axis, stalk 6-9 mm long, with a single band of air cavities, receptacle (3-)4-5 mm diameter, deeply divided to the $0.5-0.8$ of the receptacle diameter into (5-)710 lobes, generally symmetric (Figures 19, 23). Lobes broadened and/or truncate at apex. Sporophyte not seen on Malagasy specimens.

Distribution: widely distributed from South to North, not in dryer areas (Figure 76). Occurs in continental Africa. 

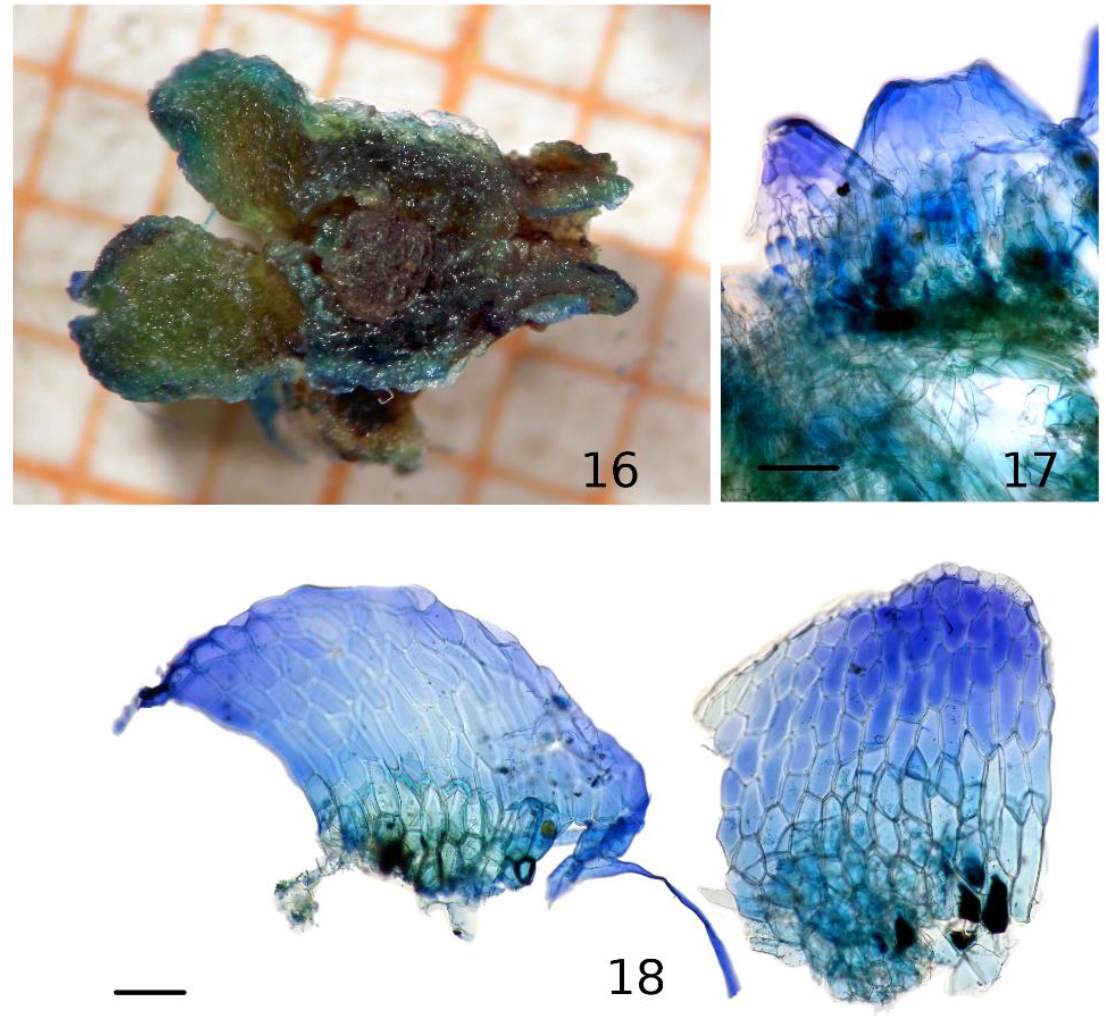

Figures 16-18. Exormotheca pustulosa Mitten. (16) Close view of a re-hydrated thallus. (17) Elevated air chamber: chlorophyllose filaments rise to more than half the high of the pore. (18) Ventral scales, Bosser 15376. Coloration with bleached (20\%), rinsed and diluted methylen blue. Scale bar $100 \mu \mathrm{m}$. 

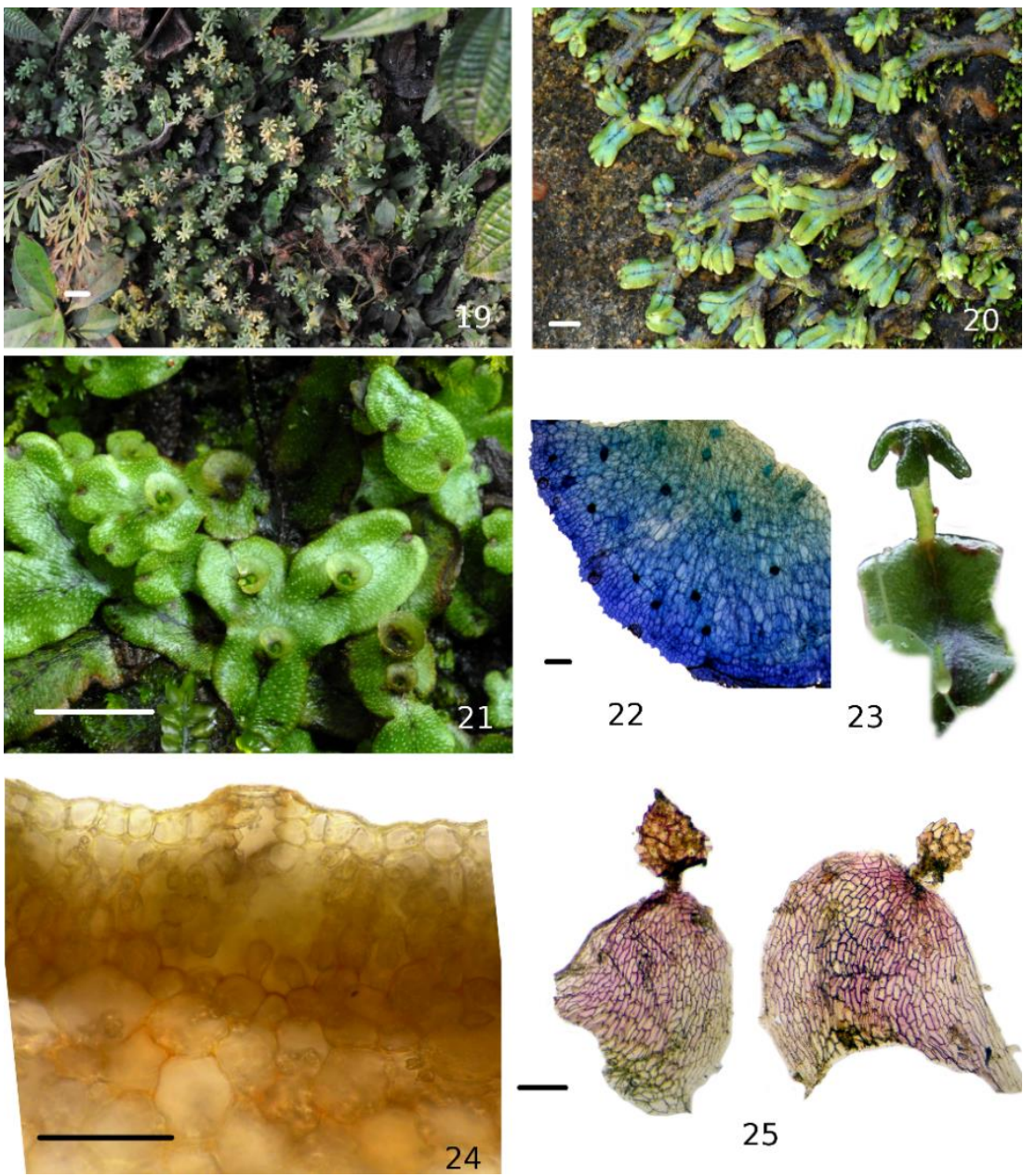

Figures 19-25. Marchantia debilis K.I.Goebel. (19) Population of M. debilis, with archegoniophores. Andasibe, Vakona Lodge, October 2015. Scale bar $1 \mathrm{~cm}$. (20) Closer view showing the typical black central line. Massif du Makay. Scale bar $5 \mathrm{~mm}$. (21) Vegetative progapules in cupules. Vohimana, 2010. Scale bar $5 \mathrm{~mm}$. (22) Lamina of the cupule: margin shortly ciliate, cilia less than 2 cells, Cremers 2685. Coloration with bleached (20\%), rinses and diluted methylen blue. (23) Archegoniophore, receptacle deeply divided. Vohimana reserve, July 2006. (24) Cross section of the thallus. Scale bar $100 \mu \mathrm{m}$. (25) Ventral scales, with relatively small appendages compared to the scale body. Scale bar $100 \mu \mathrm{m}$. 
Selected specimens examined: ANTANANARIVO, $54 \mathrm{~km}$ route de Moramanga, Anosibe, 15/09/1653, Bosser 6411 (PC-PC0738843); Ambohipotsy, 18/06/1880, Wildebrandti 4234 (PC-PC0738836); 10/1913, Waterlot 13 (PC-PC0738835), 14 (PC-PC0738833); Fort Voyron, 15/01/1921, Decary s.n. (PC-PC0738816); Mandraka Pk 69, forêt de la Mandraka, au sol, alt 1000 m, 18/07/1972, Cremers 2259; Anjozobé [Anjozorobe], 22/08/1977, Tixier s.n. (PC-PC0738840); Ambatomirahavavy, Lemurs Parc, $18^{\circ} 57^{\prime} 04.8 \mathrm{~S} \quad 47^{\circ} 21^{\prime} 2572 \mathrm{E}$, 1280m , 20/10/2015, Reeb CR15M61; Ampefy, chutes de la Lily, 1901'54.2S 46+41'03.4E, 1156 m, 19/10/2015, Reeb, Riza \& Albert CR15M51. ANTSIRANANA, Sud d'Ambanja, sur rocher, $13^{\circ} 42^{\prime} 18.01 \mathrm{~S}$ 48²7'6.93E, 13/08/1973, Cremers 2455 (TAN); Sud Est d'Ambilobe, forêt d'Anjahana, 28/08/1973, Cremers 2685, (PC-PC0167105, TAN); Ambilobe, 26/07/1939, Decary s.n. (PC-PC0738844); Analavelona, Andriamiarisoa ACR1131 (MBG); Diego-Suarez, Ambilobe, bords de la Mahavavy, s.d., Waterlot 121 (PCPC0738849); Diego-Suarez, Les Roussettes [Mt. Ambre], 06/11/1975, Tixier 7474 (PC-PC0738838), 7667 (PC-PC0738846); Nossi-Bé, mai 1879, Hildebrandt 4233 (PC-PC0738851); Parc national du Marojejy, Mandena, Andampibe valley, 22/03/1990, Pócs 90110/J (PC-PC0738839); Réserve spéciale de Manongarivo. Evergreen riverine forest along Ambakatra river, alt 90-150 m, 1354.9'S 48²7.8'E, 23/07/1998, T. Pócs, A Szabó \& R. Ranaivojaona 9855/C (EGR); Tsaratanana RNI. River Andilambe. Low elevation humid forest savoka on granite, 17/11/2001, Chris Birkinshaw 1110 (M0); Sava, Andapa, Doany, Andranomilolo forêt dense humide de moyenne altitude située à environ $13 \mathrm{~km}$ à l'Ouest du village d'Andranopositra. 14²0'32"S 49 19'05"E 1438 m, 13/11/2006, D. Ravelonarivo et al. 2048 (MO). FIANARANTSOA, [Atsimo-Atsanana], Vondrozo, Parc de Farafanga [Farafangana], 04/09/1926, Decary s.n (PC-PC0738850); Fort-Carnot, vallée de la Sandrananta, Decary s.n. (PC-PC0738847); Affluent du Haut Sascelava [Sahasinka], 14/09/1934, Heim 1424a (PC-PC0738536); vallée du Sakalena, 14/06/1939, Decary s.n. (PC-PC0738810) and 15/06/1939, Decary s.n. (PC-PC0738853); Près de Fort Carnot, Heim s.n. (PCPC0738513); MAHAJANGA, Pk 274 RN4, rivière Antetezana, Boiteau 1004 (PC-PC0738845) ; Vohitany (canton de Gogogogo), fev. 1962, 
Bosser 15416 (PC-PC0738852); Tsingy de Namoroka, on rocks along Namoroka river, under shady mangoo trees $16^{\circ} 24^{\prime} 00 \mathrm{~S} 45^{\circ} 17^{\prime} 22 \mathrm{E}$. 21/10/2016 Reeb CR16M308 TOAMASINA, Alaotra-Mangoro, Ambavaniasy, réserve de Vohimana, falaise entre pont de pierre et tunnel désaffecté, elev. 789 m, 1855'13.1S 48³0'57.1E, 13/04/2010, Reeb, Andriamanantena \& Bidault CRAE10 (PC, TAN); réserve de Vohimana, sur sentier botanique, elev. $789 \mathrm{~m}$, 1855’12.7S 48³0’57.9E, 13/04/2010, Reeb, Andriamanantena \& Bidault CRAE9, (PC, TAN); réserve de Vohimana, talus sur la rive gauche de la rivière Vohimana, elev. $798 \mathrm{~m}, 1^{\circ} 55^{\prime} 25.6 \mathrm{~S}$ $48^{\circ} 30^{\prime} 41.5 \mathrm{E}, 15 / 04 / 2010$, Reeb, Andriamanantena \& Bidault CRAE146, CRAE 150bis, CRAE151bis (PC, TAN); Réserve de Vohimana, $771 \mathrm{~m}, 8^{\circ} 55^{\prime} 15.2 \mathrm{~S} 48^{\circ} 30^{\prime} 56.1 \mathrm{E}, 10 / 07 / 2006$ Reeb MH4 (PC-PC0738877), Reeb MH6 (PC-PC0738876); Zahamena, Andriamiarisoa ACR108 (MBG); vallée de l'Anony, 05/08/1921, Decary s.n. (PC-PC0738837, PC0738841); Andasibe, Vakona Lodge, 1853'20.5S 48²5'54.6E 979 m, 24/10/2015, Reeb CR15M99. TOLIARA, Atsimo-Andrefana, Massif du Makay, camp 1, falaise sur la

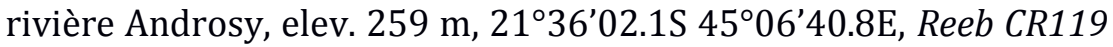
(PC-PC0738855, TAN); Massif du Makay, camp 1, au pied de la cascade de la rivière Androsy, elev. $274 \mathrm{~m}, 21^{\circ} 35^{\prime} 36.5 \mathrm{~S} 45^{\circ} 06^{\prime} 39.8 \mathrm{E}$, 12/01/2011, Reeb CR1121 (PC-PC0738854, TAN); Massif du Makay, camp 1, petit vallon affluent de l'Androsy, elev. $259 \mathrm{~m}, 21^{\circ} 36^{\prime} 13 \mathrm{~S}$ 4506'39.1E, 10/01/2011, Reeb CR1111 (PC-PC0738856), CR1116 (PC-PC0738857, TAN); Massif du Makay, camp 2, le long de la rivière d'Ambotorabatorano, elev. $303 \mathrm{~m}, 2^{\circ} 34^{\prime} 04.9 \mathrm{~S} 45^{\circ} 04^{\prime} 33.7 \mathrm{E}$, Reeb CR11132 (PC-PC0738858, TAN); Massif du Makay, camp 2, remontée rivière Ambotorabatorano, 21 ${ }^{\circ} 36^{\prime} 00 \mathrm{~S} 4^{\circ} 06^{\prime} 41 \mathrm{E}, 15 / 01 / 2011$, Reeb CR1166 (PC-PC0738859, TAN); Massif du Makay, camp 4,

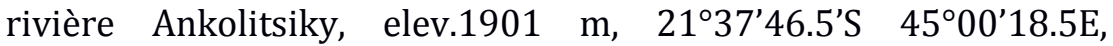
22/01/2011, Reeb CR11107 (PC-PC0738861, TAN), Reeb CR11109 (PC-PC0738883, TAN), CR11111 (PC-PC0738862, TAN); Massif du Makay, camp 4, cascade en surplomb, elev. $221 \mathrm{~m}$, 213’30.6S 4500'26.7E, 23/01/2011, Reeb CR11116 (PCPC0738860, TAN); Massif du Makay, camp 4, petit canon rive gauche

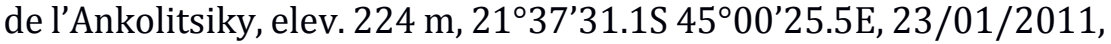
Reeb CR11112bis (PC, TAN); Fort-Dauphin, vallée de Mandrara, 
01/08/1926, Decary s.n. (PC-PC0738842); Ihosy, 20/10/1940, Decary s.n. (PC-PC0738834).

Marchantia pappeana Lehm. Novarum et minus cognitarum stirpium, pugillus X: 21 (1857); Bischl.: 76 (1993); Perold: 197 (1995c).

Type: SOUTH AFRICA, 'In Prom. B.S. leg. Pappe', ex herb. Lehmann (RO, holo.?; G ex herb. Univ. di Roma). Synonyms: M. planiloba Steph. Bot. Jahrb. Syst. 8: 90 (1886); Steph.,: 181-182 '153-154' (1886b). Type: SÃO TOMÉ, Cachoeira do Rio Manuel Jorge, circa S. Nicolau, 800 m, 1885, Moller 32 (G). M. planiloba Steph. var. walteri Burgeff: Genet. Stud. Marchantia: 276 (1943). Type: TANZANIA, 'Nderema in Ost-Usambara, etwa 1000 m, leg. H. Walter. M. wilmsii Steph.: 126 (1892). Type: SOUTH-AFRICA, Transvaal, McLea in Rehmann Hep. austro-afr. Exs. 1 (PC, BM, G, NY, S). M. parviloba Steph.: Bot. Jahrb. Syst. 20: 305 (1895). Type: UGANDA, Runssoro, um 2800 m, 10 Juli 1891, Stuhlmann 2368a (G, BM). M. winkleri Steph. in Bonner Candollea 14: 112 (1953). Type: CAMEROON, Winkler 270 (G). M. stephanii Vanden Berghen: Bull. Jard. Bot. Etat. 24: 50 (1954). Type: TANZANIA, Usambara, Holst 692 (FH, G). M. flavescens Steph. in Bonner Candollea 14: 107 (1953). Type: GUINÉE ÉQUATORIALE, det. Fernando Póo, 1911 Mildbraed 6275 (G).

Thallus dichotomous, green without median dark line (Figures $26,27)$, ventral face green or purple, medium size, 25-65 $\mathrm{mm}$ long, each axis 5-10 mm large; margins entirely purple or not. Pores well visible (Figure 27), relatively large $70-125(-200) \mu \mathrm{m}$ diameter bordered by 7-8 rings of cells, 3-4 above epidermis, 3-4(-5) projecting in air-cavities (Figure 30). Ventral scales in 4 rows not extending more than $50 \%$ of the thallus width, often purple, 800$1400 \mu \mathrm{m}$ long, oil bodies scattered; appendages rounded, orbicular or broadly triangular, 450-750 $\mu \mathrm{m}$ long, 330-550 $\mu \mathrm{m}$ wide, bordered by an irregularly toothed margin with one-celled teeth or regular margin (Figure 28). Cupules with cilia 2-3(-6) cells long. Dioicous. Antheridiophores at apex of axis, stalk 22-25 mm long, in cross section with 2 bands of air cavities, receptacle (5-)10-13(-14) $\mathrm{mm}$ diameter, palmate and divided in into (6-)7-9 rays more or less asymmetric (Figure 29). Archegoniophores at apex of the axis, stalk 
10-20 mm long, in cross section with two bands of air cavities (Figure 31), receptacle (5-)6-7(-11) mm diameter divided up to the quarter of the receptacle diameter into (8-)10-12 flat lobes (Figure 26). Spores 17-35 $\mu \mathrm{m}$.

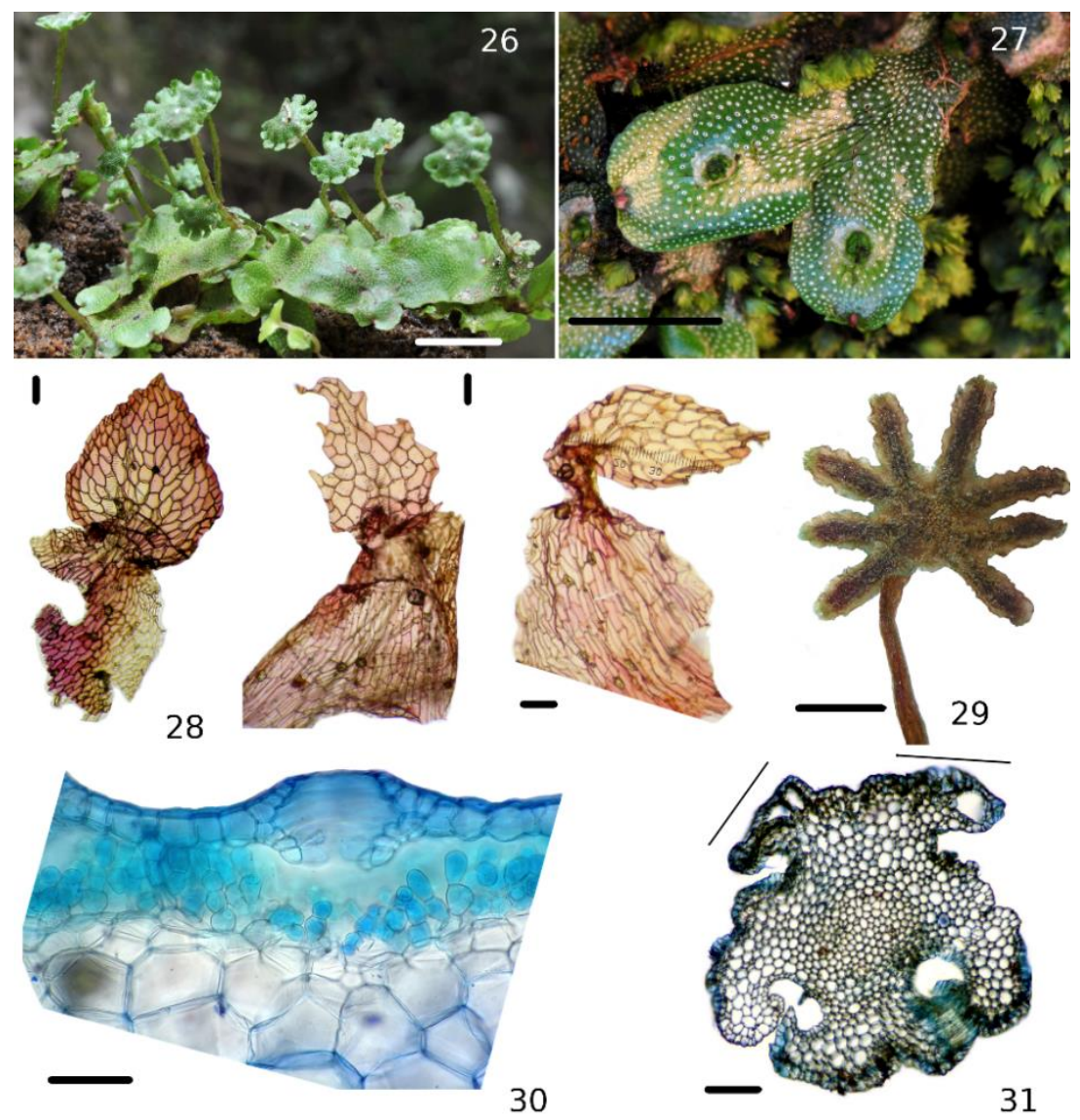

Figures 26-31. Marchantia pappeana Lehm. (26) Fertile population, with archegoniophores. Zahamena January 2014. Scale bar $1 \mathrm{~cm}$. (27) Close view of a thallus showing the large pores easily visible by eyes, no central black line. Massif du Makay. Scale bar $1 \mathrm{~cm}$. (28) Ventral scales, Cremers 1987 and Bosser 13282. Scale bar $100 \mu \mathrm{m}$. (29) Antheridiophore. Scale bar $1 \mathrm{~cm}$. (30) Cross section of the thallus. Coloration with bleached (20\%), rinses and diluted methylen blue. Scale bar $100 \mu \mathrm{m}$. (31) Cross section of the stalk of an archegoniophore showing 2 opposite bands of air chambers (black lines). Scale bar $100 \mu \mathrm{m}$. 
Distribution: widely distributed from South to North, not in dryer areas (Figure 77). Widely distributed in tropical Africa.

Ecology: on edges of water (waterfalls, rivers with slow current, ponds), terrestrial banks in shaded or open and exposed areas, on damp soils or rocks, sometimes flooded.

Bischler (1993), distinguished two subspecies of M. pappeana, $M$. pappeana subsp. pappeana and M. pappeana subsp. robusta, but only the former is found in Africa including Madagascar. In the African flora of Jones (2004) only the species M. pappeana is cited, we retained that choice.

Selected specimens specimen examined: ANTANANARIVO, 22/04/1906, Alleizette 7bis (PC-PC0738822); Tsimbazaza, tourbière de Tsimbazaza, sur terre, elev. 1250 m, 06/08/1972, Cremers 2409 (PC-PC0738825, TAN), Cremers 2417 (TAN); elev. 1100 m, 09/10/1927, Decary s.n. (PC-PC0738793); centre route du Sud Pk 210 , rochers humides et ombragés, 01/12/1951, Bosser 1254 (TAN); Pk 28 route du Sud, paroi rocheuse humide et ombragée, 01/09/1957, Bosser 12232 (PC-PC0738832, TAN); Behenjy face Est 36 km Sud d'Antananarivo, elev. 1400 m, 07/09/1972, Cremers 2325 (PC-PC0738827, TAN); Manjakatompo, 16/08/1934, Heim s.n. (PCPC0738524); Manjakatompo, 25/05/1951 Benoist 1076 (PCPC0738796), Benoist 1076 (PC-PC0738808); Imerina, Janv. 1881, leg. Wildebranti 4235 (PC-PC0738792); Mandraka Pk 69, forêt de la Mandraka, au sol, alt $1000 \mathrm{~m}, 18 / 07 / 1972$, Cremers 2257 (PCPC0738828, TAN), Cremers 2258 (PC-PC0738831, TAN), Cremers 2259 (PC-PC0738830, TAN); Mandraka, août 1906, d'Alleizette 84 (PC-PC0738821); cascade de la Mandraka, 16/08/1953, Bosser 6028 (PC-PC0738788); Mandraka, fev. 1953, Bosser 5028 (PCPC0738804); forêt de la Mandraka, elev. $800 \mathrm{~m}, 31 / 03 / 1972$, Cremers 1987 (PC-PC0738826, TAN); forêt de la Mandraka, talus ombragé humide, 01/09/1959, Bosser 13282 (TAN); Mandraka, Gilles, (PC); Tananarive, Ambohimanga, bouquetau, juin 1914, Waterlot 167 (PC-PC0738801), 169 (PC-PC0738798); MAHAJANGA, Bealana, Mangindrano, forêt de moyenne altitude d'Antsahivo sur rocher au bord de la rivière 02/12/2005 R.L.Andriamiarisoa 662 (MO-66223240). ANTSIRANANA, entre Vohémar et Ambilobe, 29/07/1939, Decary s.n. (PC-PC0738809); entre Vohémar et 
Ambilobe, 30/07/1939, Decary s.n. (PC-PC0738807); Marojejy, roche humide le long de la rivière Manantenina, elev. 600-700 m, 12/02/1989, Miller \& Lowry 4009 (TAN); massif du Betsomanga, Antongondriha, vallée inférieure de l'Androranga, 17-20/11/1950, leg. Humbert \& Capuron (PC-PC0738818); Nord d'Anosibe, 17/02/1930, Decary s.n. (PC-PC078814); Tsaratiteraka (Tsianovoha), Heim 1350a, (PC-PC07738511); Diego-Suarez, Joffreville, domaine de Fontenay, 28/08/2010, Reeb CR2010M (PC); FIANARANTSOA, [Ranomafana], vallée du Namorona, 22/111938, Decary s.n. (PC-PC0738794); Ambatomboay, Octobre 1934, Heim s.n. (PC); Andrambovato, 27/04/1979 Tixier 12391 (PC-PC0738824), 12393 (PC-PC0738823); Farafanga, Befotaka, 16/08/1926, Decary s.n. (PC-PC0738815); Fianarantsoa-Masongary Pk 28, chutes de Ranomafana, sur rochers en sous-bois, elev. 1165 m, 01/05/1972, Cremers 2097 (TAN); parc national de Ranomafana, Along the N side of main road at the head the big waterfalls of Namorona river. Alt 1080-1150 m, 21ํ14.70-86'S 47²23.82'E, 29/07/2004, S. \& T. Pócs 04126/AO, 04126/AN, 04126/AZ (EGR). Forêt de Saharevo, 01/09/1934, Heim s.n. (PC-PC0738529); Forêt de Saharevo, 02/09/1934, Heim s.n. (PC-PC0738531); Station forestière d'Andrambovato, elev. 1030 m, 01/11/1956, Decoings 1848 (TAN); Vallée du Sakalena, 13/06/1939, Decary s.n. (PC-PC0738787); TOAMASINA, sud de Moramanga, entre Sandrangato et Anosibe, 37/11/1952, Leandri 1572 (PC-PC0738806), 1600C, 1603bis (PCPC0738799); $54 \mathrm{~km}$ route de Moramanga, Anosibe, 15/09/1953, Bosser 6410 (PC-PC0738786); Ambatovavy, Bamafo river, Andriamiarisoa ACR635, ACR662 (MBG); Ambohimangakely, Decary s.n. (PC); Analamazaotra, en forêt, 15/04/1939, Decary s.n. (PCPC0738789); Imerimandroso, 0207/1921, Decary s.n. (PCPC0738812); Nord d'Anosibe, 18/02/1930, Decary s.n. (PCPC078803); Périnet, talus humide en borêt, Boiteau 0228 (PC); près d'Ambositra, Decary, (PC); Forêt de Périnet, 9/11/1951, Benoist 1822 (PC-PC0738800, PC0738805); Forêt de Périnet, elev. 900-1000 $\mathrm{m}, 02 / 10 / 1971$, Cremers 1928 (PC-PC0738829, TAN); station forestière de Périnet, 13/05/1966, Boiteau 216 (PC-PC0738797), 228 (PC-PC0738790); Sud de Moramanga, entre Sandrangato et Anosibe, alt 800-1100 m; Alaotra-Manongarivo, Réserve de 
Vohimana, $771 \mathrm{~m}, 1^{\circ} 55^{\prime} 15.2 \mathrm{~S}$ 48 30'56.1E, Reeb MH1 (PCPC078878); Andasibe, Vakona Lodge, $18^{\circ} 53^{\prime} 20.5 \mathrm{~S} 48^{\circ} 25^{\prime} 54.6 \mathrm{E}, 956$ m, 24/10/2015, Reeb CR15M100; Zahamena, 1H30 de Ranofotsy, le long de la rivière Ankotrokotroka, $1169 \mathrm{~m}, 17^{\circ} 36^{\prime} 39 \mathrm{~S} 48^{\circ} 40^{\prime} 21 \mathrm{E}$ Reeb \& Andriamanantena CR13Z82 (PC-PC0738879), CR13Z74 (PCPC0738880), CR13Z82 (PC-PC0738881); Maroantsetra, 20/10/1920, Decary s.n. (PC-PC0738817); TOLIARA, col de Tapia, 29/12/1976, Tixier 10071 (PC-PC0738813), 10079 (PCPC0738811); Massif du Makay, cascade rivière Androsy, elev. 274 m, 213’36.5S 4506'39.8E, 12/01/2011, Reeb CR1120 (PCPC0738882, TAN); Massif du Makay, au pied marécage tourbeux,

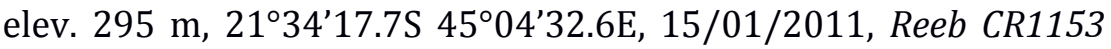
(PC-PC0738864, TAN); Midongy du Sud, 23/06/1926, Decary s.n. (PC-PC0738802).

It appears that in African historical collections, M. debilis and $M$. pappeana were often identified as several species listed now as synonyms (Bischler 1993, Grolle 1995). They were sometimes misidentified and often confused (Bischler 1993, Jones 2004). Several specimens were identified as Marchantia globosa Brid. ex Web. which is only encountered in Comores, Mauritius and Réunion islands (Bischler 1993).

The examined Malagasy specimens of Marchantia are all related to M. debilis or M. pappeana. The two species can be separated on by: (1) size, width of the thallus and diameter of the receptacle of the antheridiophore, (2) diameter of the pores (Figure 32), (3) size of the appendage of ventral scales (always smaller in $M$. debilis), (4) absence of median dark line in M. pappeana, ciliation of the cupules (shorter in M. debilis). The number of rings around the pores and cells projecting above epidermis and in air cavities appears variable but if associated with the pore diameter, the two species are distinct. If the plants are fertile, the number of bands of air-cavities in gametangiophores can also distinguish the species (one in M. debilis, two in M. pappeana). The diameter of spores overlaps and cannot be a diagnosis character. The two species are often in mixed populations (see Cremers 2259). 

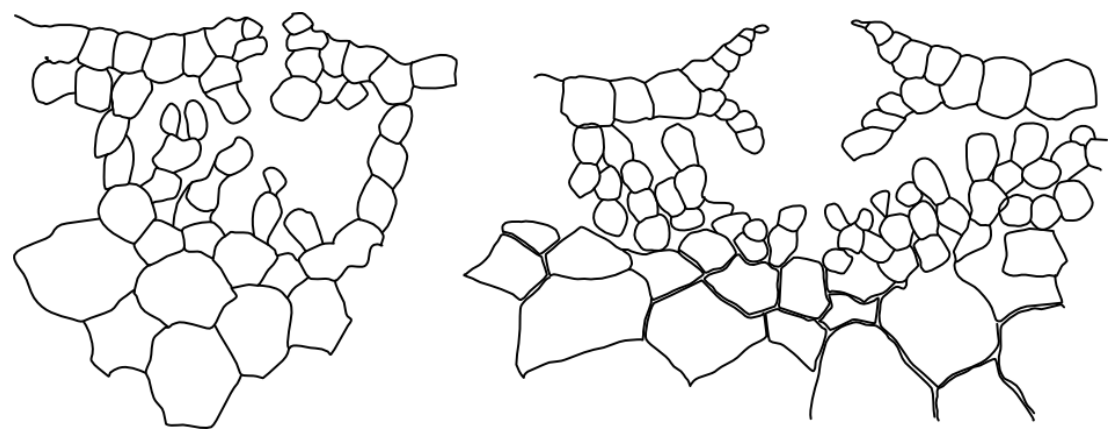

Figure 32. Comparison of the pores in cross section of (left) Marchantia debilis, Cremers 2455 and (right) Marchantia pappeana, Reeb CR1153.

\section{RICCIACEAE}

Riccia atromarginata Levier var. jovet-astii Rauh \& Buchloh Revue Bryologique et Lichénologique 30: 77. 1961.

Type: MADAGASCAR Gneis-Hügel bei Fianarantsoa (Madag. Centr.) December 1959 N 1900 leg. W. Rauh (isotype PC-PC0103703!).

Thalli in incomplete or partial rosettes, lobes linear to ovate, very narrow but deep central groove, apex emarginate; glaucous-green to bright green with dark purple flanks (Figure 33), small, less than 10 mm long, lobes $0.5-1 \mathrm{~mm}$ wide (Figure 34 ); in cross section as wide as thick, without bulging lobes, margin rounded, dorsal epithelium unistratose, cells globose, assimilation tissue in vertical columns of 6-8 isodiametric cells; marginal cilia curved and interlocking on dorsal face, in several rows, sometimes sparsely covering the dorsal face (Figures 35, 36), cilia smooth (80-) 150-250(-300) $\mu \mathrm{m}$ long. Ventral scales not reaching the margin of the thallus, purple or hyaline in part. Dioicous. Antheridia with prominent hyaline neck (not seen on Malagasy specimens). Archegonia with purple necks (not seen on Malagasy specimens). Several sporophytes per lobes (up to 3), slightly bulging on dorsal face. Spores massively black in mass, brown when alone, globular and irregularly triangular or polygonal with rounded angles, not winged, 68(-92) $\mu$ m diameter; ornamentation similar on both faces, 10-12 rounded alveoli in diameter, separated by thick edges. 


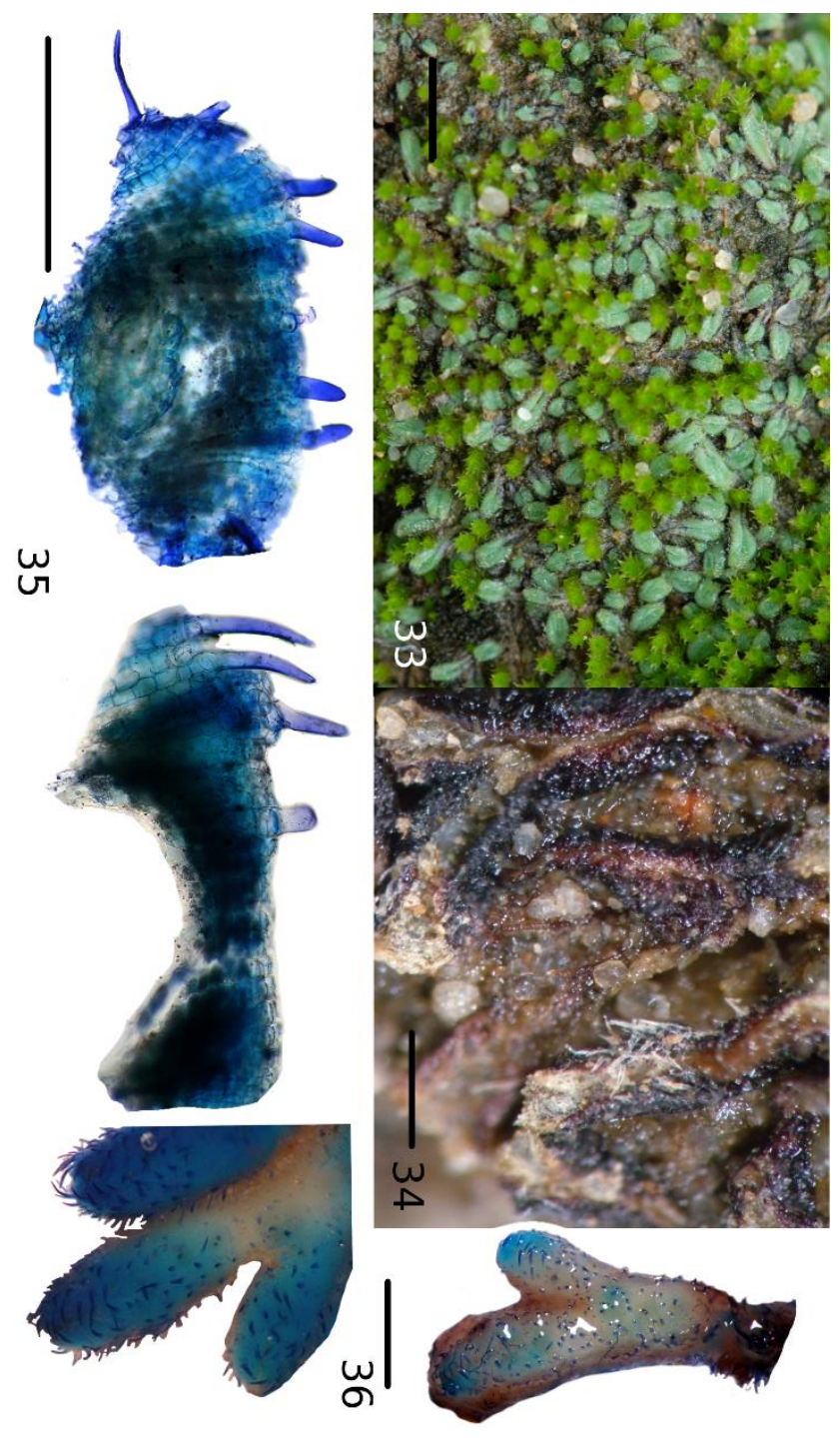

Figures 33-36. Riccia atromarginata Levier var. jovet-astii Rauh \& Buchloh. (33) On the field in the Makay Massif, Reeb CR11104. Scale bar $1 \mathrm{~cm}$. (34) Dry specimen showing the black-red flanks, Bosser 15420. Scale bar $1 \mathrm{~mm}$. (35) Cross section of thallus, Onraedt 70M02. Scale bar $500 \mu \mathrm{m}$. (36) Lobes with paler margins after coloration, but allowing observation of ciliae and dorsal papillae in good conditions, Onraedt 70M02. Coloration with bleached (20\%), rinses and diluted methylen blue. Scale bar $1 \mathrm{~mm}$. 
Distribution: three localities, one in Tsimbazaza park, Southern, dry and lowland areas (Figure 79). Occurs in European Mediterranean countries, North Africa, Arabic peninsula and Socotra.

$R$. atromarginata var. jovet-astii is recognized by: (1) the small size of the thallus, (2) the marginal cilia and the dorsal cilia-papilla, (3) the low and inconspicuous purple scales, (4) the distal face of spore with thickened walls.

Ciliate Riccia are rather problematic taxa, with taxonomy not fully resolved. Grolle (1995) retained $R$. atromarginata var. jovet-astii and Riccia trichocarpa Howe for Madagascar. Kürschner (2000) reported it from several localities in Yemen. In the recent check-list (Marline et al. 2012), the only ciliate Riccia cited is Riccia crinita Taylor. As stated by Jovet-Ast (1986), R. crinita is an Australian species that she considered with doubt as synonym for $R$. trichocarpa. Grolle (1995) considered R. trichocarpa as a critical taxon, based on Jovet-Ast's remarks. Then, Perold (1999) recognized $R$. trichocarpa for South-Africa, but did not mention at all $R$. crinita! However, the ciliate Malagasy specimens cannot be $R$. trichocarpa or $R$. crinita, because of their very small size, the shorter cilia and smaller spores without wing.

This variety was described from one collection from Fianarantsoa (Rauh and Buchloh 1961) then Jovet-Ast $(1955,1989)$ discussed the "atromarginata" complex, including this variety. The distinction between cilia and papilla is not evident, dorsal papilla are described as finger-like and shorter (182-190 $\mu \mathrm{m}$ ) than cilia (up to $430 \mu \mathrm{m}$ ), which are also slightly curved. We found that papilla could also be small cilia, and we could not find real distinction between the two in in literature.

The examination of the type specimens shows a morphological similarity between $R$. atromarginata and $R$. atromarginata var.jovetastii. The latter is a little bit smaller and its spores bear thicker cell walls between alveoli (as noticed by Jovet-Ast 1989); we did not find that spores have pillar (thickness) at angles of the alveoli as described and illustrated in Rauh and Buchloh (1961).

Specimens examined: ANTANANARIVO, Tsimbazaza, $1200 \mathrm{~m}$, 14/01/1970, Onraedt 70MO2 (PC-PC738909); TOLIARA, Sud PK 434 
Route Amboasary-Ft.Dauphin [Amboasary], fév 1962, Bosser 15420, (PC-PC0738908, PC0716004); Massif du Makay, camp 3, sur rochers, elev. 176 m, S 2140'14.6 E 4459'22, 20/01/2011, Reeb CR1192 (PC-PC0738910, TAN), Reeb CR1197 (PC-PC0738911, TAN).

Supplementary material examined Riccia atromarginata Levier Type: SICILIA Villa Belmonte prope Panormum, 25 Dec 1888, Dr. H.Ross s.n. (PC-PC0103704!).

Riccia atropurpurea* Sim. Trans. Roy. Soc. S. Afr. 15: 11. 1926.

Type: SOUTH AFRICA, Natal, Edendale Falls, Sim 8112 (lectotype, PRE-CH1023). Thalli in incomplete rosettes up to $20 \mathrm{~mm}$ across, glaucous green with a white margin, lobes with a deep central furrow (Figure 37), 5-8(-10) $\mathrm{mm}$ long, often a smaller branch bifurcating below apex; when dry, margins clasp together dorsally, hiding the dorsal face, then covered by the ventral scales; in cross section, assimilation tissues in parallel lines with narrow airchambers; epidermal cells soon collapsing, with thickened cell walls (Figure 39). Ventral scales obvious, black and bright, the white margin forming two lips rising upon the central part of the thallus (Figure 38). Spores 70-90 $\mu \mathrm{m}$ (Figure 40).

Distribution: from North to South, in a discontinuous distribution (Figure 81). Occurs in Sub-Saharan Africa.

Ecology: very common on exposed banks of the canyons in the Makay Massif, on temporary humid sandstone plates.

The species is easily recognizable by (1) the dorsally collapsing flanks, (2) the hyalin-white line bordering margins and (3) the thickened cell walls of the epidermis. 

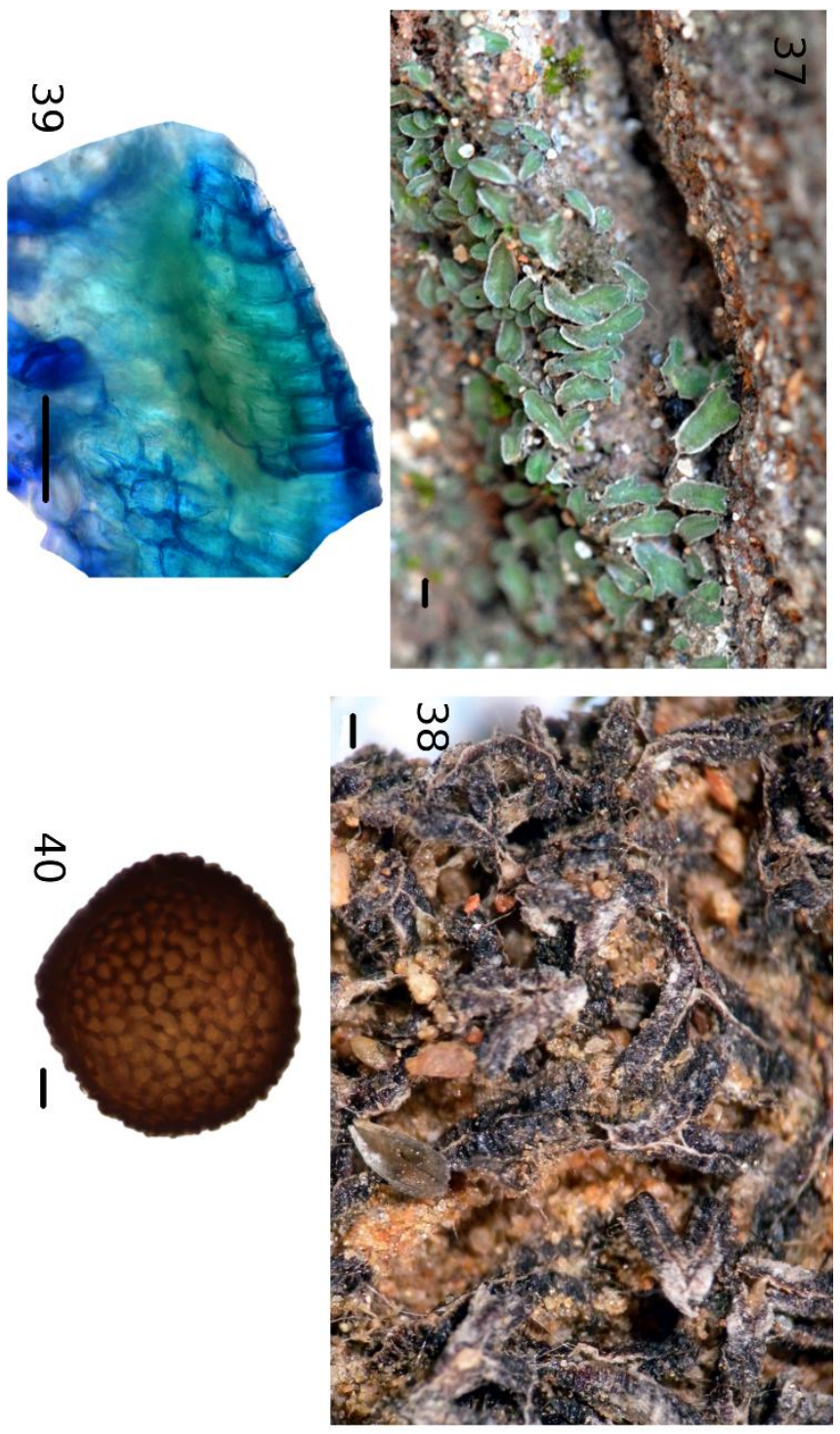

Figures 37-40. Riccia atropurpurea Sim. (37) On the field, humid thalli showing thin, white margins. Makay Massif, 2011. Scale bar $1 \mathrm{~mm}$. (38) Dry thalli, dorsal faces clasping and white margins forming two lips. Scale bar $1 \mathrm{~mm}$. (39) Cross section showing collapsed epidermal cells with thickened cell walls. Scale bar $100 \mu \mathrm{m}$. (40) Spore, distal face. Scale bar $10 \mu \mathrm{m}$. 
Selected specimens examined: ANTANANARIVO, 24/12/1923, Decary s.n (PC-PC0738906); Tsimbazaza, chemin du jardin botanique, sol minéral, 14/03/1970, Onraedt (TAN); Tsimbazaza, Déc. 1960, Bosser 14797 (PC-PC0715996, TAN); TOLIARA, $10 \mathrm{~km}$ avant Betroka, rocher temporairement humide, Fév. 1963, Bosser 16908 (PC-PC0715985, PC0715997, TAN); Route de Betroka PK 6566, Fév. 1963, Bosser 16909 (PC-PC0715995); Forêt d'Anjahana, au sud-est d'Ambilobe, 28/08/1973, Cremers 2687-a (PC-PC0715986); Massif du Makay, camp 2, rive droite Ambotorabatorano, elev. 295 $\mathrm{m}, 21^{\circ} 34^{\prime} 13 \mathrm{~S}$ 450.'32.3E, 15/01/2011, Reeb CR1159 (PCPC0738895, TAN), Reeb CR1160 (PC-PC0738896, TAN); Massif du Makay, camp 2, vallon à gauche en remontant la rivière Ambotorabotorano, 16/01/2011, Reeb CR1173 (PC-PC0738897, TAN); Massif du Makay, camp 3 remontée de l'Ankolitsiky, gros bloc, 18/01/2011, Reeb CR1176 (PC-PC0738898, TAN), CR1183 (PCPC0738896, TAN); Massif du Makay, camp 3 forêt d'Ambalamanga,

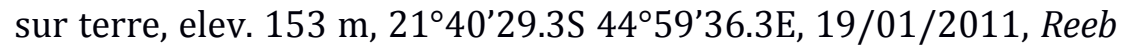
CR1186, (PC-PC0738899, TAN), CR1187 (PC-PC0738900, TAN), CR1189 (PC-PC0738901, TAN); Massif du Makay, camp 3, sur rocher,

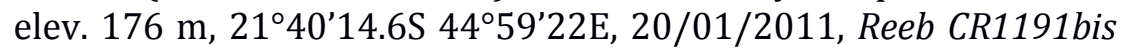
(PC-PC0738902, TAN), CR1193 (PC-PC0738903, TAN); Massif du Makay, camp 3, rocher sur sable, elev. $176 \mathrm{~m}, 21^{\circ} 40^{\prime} 14.6 \mathrm{~S}$ 44ㅇ5'22E, 20/01/2011, Reeb CR11102, CR11105; Massif du Makay, camp 4, falaise, elev. $214 \mathrm{~m}, 21^{\circ} 37^{\prime} 25.2 \mathrm{~S} 45^{\circ} 00^{\prime} 05.0 \mathrm{E}, 23 / 01 / 2011$, Reeb CR11118, CR11119, CR11121.

Riccia cavernosa Hoffm. Deutschland Flora 2: 95. 1796.

Synonym: Ricciella rautanenii Steph. Bulletin de l'Herbier Boissier 3: 374. 1895. Type: Africa occidentalis in agro Herera propre Usab in albeo fluminis Tsoacahub as terram. leg. M. Rautanen.

Thallus often in regular rosettes up to $30 \mathrm{~mm}$ wide (Figure 41), bright green to yellowish green, lobes up to $3.5(-4) \mathrm{mm}$ wide, $10 \mathrm{~mm}$ long, becoming spongious and lacunose with age (disintegration of upper epidermis) (Figures 41, 42, 43). Ventral scales absent or evanescent. Monoicous. Antheridia and archegones sunk in the thallus. Sporophyte protruding somewhat ventrally, even if visible dorsally, numerous, crowded. Spores reddish brown to black, 
triangular-globular, winged, (60-)64-90(-120) $\mu \mathrm{m}$ with a network of few ridges forming sometimes complete alveoli, proximal face with a conspicuous triradiate mark (Figures 44, 45, 46).

Distribution: central and southern areas, $0-1200 \mathrm{~m}$ in a discontinuous distribution (Figure 81). Cosmopolitan species.

Ecology: $R$. cavernosa is a hygrophilous species occurring on fresh muddy soils close to rivers.

This species is easily recognizable by the spongious and lacunose thallus, mostly in rosettes. $R$. crystallina too has this spongious habit and may be confused. The two species were thoroughly compared by Jovet-Ast $(1964,1966,1986)$ and Perold (1995b, 1999). They may be confused, but the latter one has not been identified for Madagascar. The main differences being on spore ornamentation (complete alveoli in $R$. crystallina) and size, smaller for $R$ crystallina even if they overlap (60-86.5 $\mu \mathrm{m}$ for $R$. crystallina; 60-120 $\mu \mathrm{m}$ for $R$. cavernosa).

Specimens examined: ANTANANARIVO, environs de Tananarive, PK22 route d'Arivonimamo bord de ruisseau, nov. 1960, Bosser 14698 (PC -PC0716016); environs de Tananarive, PK23 route d'Arivonimamo terre mouillée bord de rivière, nov. 1957, Bosser 12299 (PC-PC0716018); mbatomirahavavy, Lemurs Parc, $18^{\circ} 57^{\prime} 04.8 \mathrm{~S} 4^{\circ} 21^{\prime} 25.2 \mathrm{E}, 1266 \mathrm{~m}, 20 / 10 / 2015$, Reeb CR15M66 FIANARANTSOA, chutes de l'Ikopa, sables humides bord de rivière, alt. 1200 m, août 1955, Bosser 8316 (PC -PC0716015); ToAMASINA, Ambohijanahary, W. lac Aloatra terre humide en bord de ruisseau, juin 1955, Bosser 8144 (PC -PC0716017); au bord du Fiarenana [Fiherenana], à Sakaraha, sur terre sabloneuse ombragée champ cultivé, alt. 380 m, 01/07/1971 Onraedt 71M5500 (PC-PC0716018); au bord du Fiherenana, près de Miary, sur limon exondé du fleuve, alt. ca. 200 m, 30/06/1971, Onraedt 71M5527 (PC-PC0716021); TOLIARA, bord de l'Onilahy, près de Ambohimahavelona, sur limon exondé au bord du fleuve, alt. ca. 30 m, 29/09/1971, Onraedt $71 M 5501$ (PC-PC0716020); Manombo, côte sud-est, sur argile à nu par le retrait des eaux, bush à l'ombre des arbres, alt. $20 \mathrm{~m}$, 26/06/1971 [1972 on original label], Onraedt 71 M5502 (PCPC0716022). 

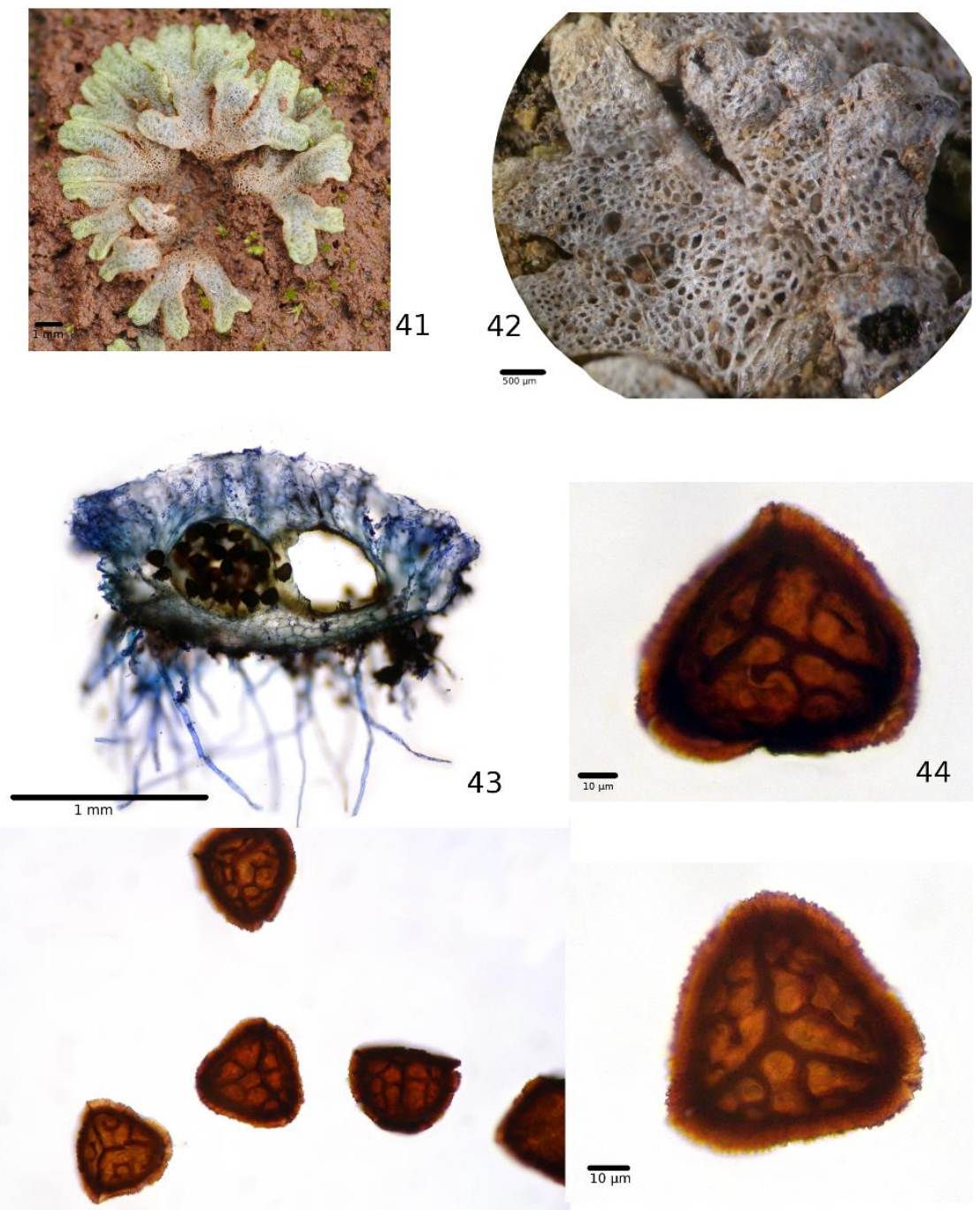

45

Figures 41-46. Riccia cavernosa Hoffm.. (41) Rosette with lacunose areas. Antananarivo, Lemurs Parc, 2015. Scale bar $1 \mathrm{~mm}$. (42) Detail of a lacunose area, Bosser 14698. Scale bar $500 \mu \mathrm{m}$. (43) Cross section of a thallus with an embedded sporophyte and large, ill-defined air-chambers. Scale bar $1 \mathrm{~mm}$. (45) Spores. (44) (46) proximal faces of spores, Bosser 14698. Scale bar $10 \mu \mathrm{m}$. 
Riccia congoana* Steph. Bull. Herb. Boissier 6: 328, 1898.

Type: CONGO, Fr. Equatorial Africa, Forêts de Ceseles, Voz M. de F., s.n. (holotype, G-00067873).

Synonyms: Riccia rhodesiae S.W.Arnell. Bot. Not. 105: 313, 1952. Type: ZIMBABWE (S. Rhod.), Victoria Falls, on soil near Trolley Junction, 11/11/1951 S.W.Arnell 1291 p.p., (holotype, S-B45273; BOL; PRE). Riccia berriei E.W.Jones. Trans. Brit. Bryol. Soc. 3: 224, 1957. Type: NIGERIA, St Anne's Churchyard, Kudeti, Ibadan, Berrie 1956. Riccia nigrosquamata E.W.Jones. Trans. Brit. Bryol. Soc. 3: 222, 1957. Type: TANZANIA Tanganyika, Lighthouse Island, Dar-esSalaam Harbour, Jones 699 (BM, holotype). Riccia aegyptiaca S.W.Arnell. Bot. Not. 116: 9, 1963. Type: EGYPT, Gebl. Elba Dist., Wadi Aideib, 21/01/1962 M. Kassas s.n. (holotype, S-B43872; isotype, CAI). Riccia limbatoides O.H.Volk. Vegetatio 55: 58, 1984. Type: NAMIBIA, Grootfontein, Farm Gaikos, Volk 00747 (M, PRE).

Thalli light to dark, green to bluish-green, in dense overlaying patches, generally in partial rosettes, large, 25-30 mm across; often bifurcated in two tongue-like branches, black scales forming a narrow scalloped border (Figures 47, 48), lobes (-2)-3-5 mm large, reticulate when young, degenerating in old age, with a narrow furrow all along the thallus, sometimes bifurcating near the apical zone, on larger or older thallus. In cross section, flanks very obliques, margin overhanging (Figure 49); dorsal epiderm unistratose, soon collapsing, assimilation tissue nearly half of the thallus thickness (Figure 49). Ventral scales black and conspicuous, shiny, adherent to the flanks and not easily removable (Figures 47, 50). Monoiocous. Antheridia along the furrow, projecting. No sporophytes seen.

Distribution: southern areas in open and dry lands at low elevation (Figure 79). Occurs in Africa.

Ecology: in semi-shaded position, at the bottom of bushes, on shaded sandstone or muddy banks.

$R$. congoana seems to be quite common in the Makay massif, and a few specimens have been found in the same type of environment in Toliara province (Figure 79); it is often close to $R$. atropurpurea stations, but always in a more shaded area. 

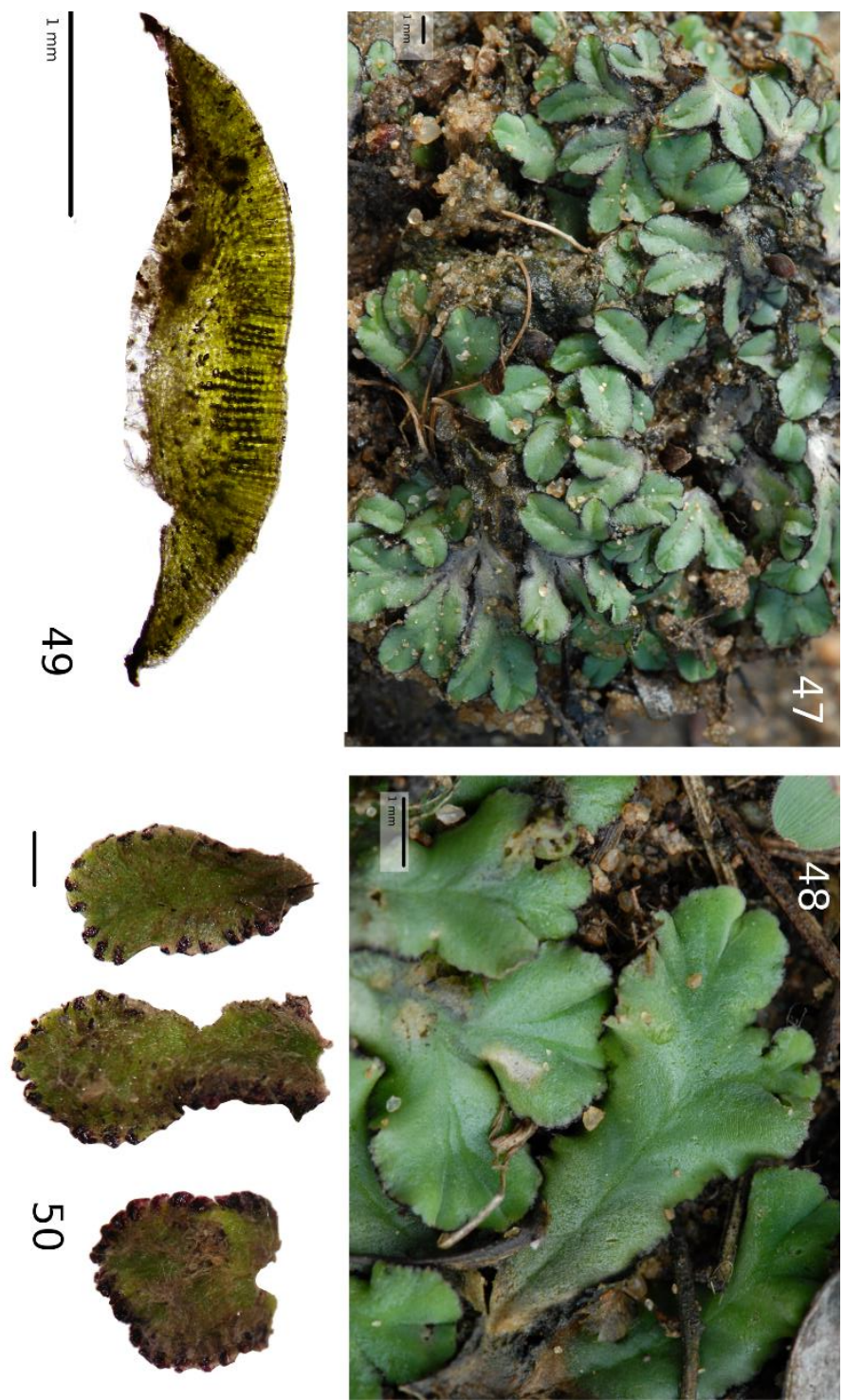

Figures 47-50. Riccia congoana Steph.. (47) (48) On the field in the Makay massif, Reeb CR11103. Scale bar $1 \mathrm{~mm}$. (49) Cross section of a thallus, Reeb CR1172. Scale bar $1 \mathrm{~mm}$. (50) Ventral faces with scalloped margins, Reeb CR11103. Scale bar 1 $\mathrm{mm}$. 
This species is recognized by (1) its large size, $R$. congoana is the largest Riccia in Madagascar; morphologically close species are $R$. angolensis Steph. and R. okahandjana S.W. Arnell (not cited for Madagascar), which are smaller, (2) the scalloped margin drawn by the scales and (3) the overhanging margins. Flanks of close species rise more vertically with no overhanging margins. It is necessary to collect fertile specimen of $R$. congoana to confirm vegetative characters.

Specimens examined: TOLIARA, RN11 piste forestière d'Imonty, Keranden 1544 (PC-PC0715991, TAN); Tombeaux des rois Mahafaly à 45 km Sud d'Ampany, Mars 1964, Bosser 17811 (PC-PC0715994, TAN); Antanimora (S.0) déc 1959, Bosser 13364 (PC-PC0738907); Massif du Makay, après piste aéroport Berohoroho, bord de lavaka, S 213'22 E 4509'67.2, 09/01/2011, Reeb CR111, CR111 bis; Massif du Makay, camp 2, rive droite Ambotorabatorano, elev. $295 \mathrm{~m}, \mathrm{~S}$

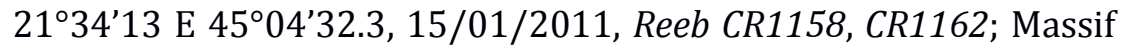
du Makay, camp 2, premier vallon à gauche en remontant la rivière

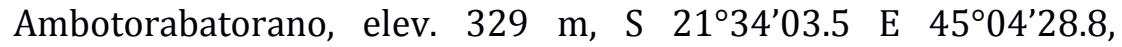
16/01/2011, Reeb CR1172, CR1174, CR1180; Massif du Makay, camp

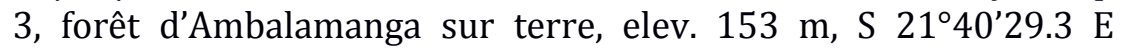
4459'36.3, 19/01/2011, Reeb CR1188; Massif du Makay, camp 3

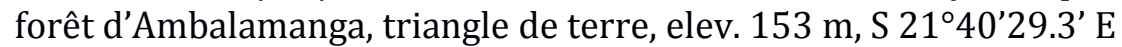
4459'36.6, 19/01/2011, Reeb CR1189; Massif du Makay, camp 3,

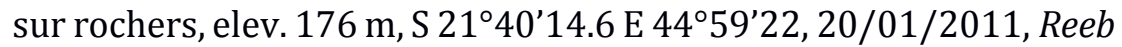
CR1195; Massif du Makay, camp 3, sur rochers, elev. $176 \mathrm{~m}, \mathrm{~S}$ 21ํㅇ'14.6 E 4459'22, 20/01/2011, Reeb CR1198, CR11103 (PCPC0738905, TAN).

Riccia cf. purpurascens Lehm. \& Lindenb. Linnaea 4: 371. 1829. Type: Cape crescit humi in sylvula quercina ad latus boreale et ad radicem montis Tafelberg. Ecklon in Herb. L. Thallus in small ribbons, overlapping in dense populations (Figure 51), light green, margins undulated or straight; branches narrow, up to $5 \mathrm{~mm}$ long and $2 \mathrm{~mm}$ wide, apex narrowed and emarginate (Figure 52); dorsal epidermis areolate, groove narrow and distinct in the apical region, slightly enlarging after. In cross section, thallus concavo-convex to plano-convex with flanks oblique in older parts (Figure 54), 
assimilation tissue occupying most of the height of the thallus. Air chambers more or less visible, in cross section in 2-3 layers. Ventral scales hyaline, towards apex. Dioicous. Sporophyte bulging ventrally (Figure 53). Spores light brown to orange, semitranslucent, 70-80 $\mu \mathrm{m}$ diameter, with. 8-10 complete or reticulated alveoli on distal face (Figure 55). Triradiate mark on proximal face with incomplete alveoli.

Distribution: two localities, Tsimbazaza and Makirovana (Figure 80). South-Africa.

Ecology: Malagasy specimens are located in humid areas (Tsimbazaza park in Central plateau, and Makirovana in eastern humid forest), on naked and humid soil.

Specimens examined: ANTANANARIVO, Antananarivo, sur terre près des serres du parc de Tsimbazaza, elev. $1250 \mathrm{~m}, 06 / 08 / 1973$, Cremers 2418 (PC-PC0715987); ANTSIRANANA, Makirovana, Ambodimanga au pied de Makirovana, elev. $41 \mathrm{~m}, 14^{\circ} 11^{\prime} 13.6^{\prime \prime S}$ 4959'09.2"E, 03/05/2010, Reeb CR203 (PC).

In Malagasy specimens identified as $R$. purpurascens, although the number of alveoli on spore distal face is higher than in the type, and we could not observed the ventral tubercules. But all other characters match the description, especially the narrowed apex, the deep groove in apical region and the keeled ventral face.

The Riccia fluitans L. complex is very problematic (Schuster 1987, Jovet-Ast 1986, Manju et al. 2012) and its status for Africa has been lengthily discussed by Perold (1990, 1999). According to Perold (1990), a clarification of the $R$. fluitans complex is much needed. We follow Perold's treatment, and two species are considered to be present in Madagascar, $R$. stricta and $R$. purpurascens. $R$. purpurascens was considered as endemic from the Cape province and we do not exclude that $R$. cf. purpurascens could be another variation in the fluitans complex.

The distinction between $R$. stricta and $R$. purpurascens are: (1) groove marked in $R$. purpurascens, and sporophyte ventral with a straight collar. (2) in R. stricta, sporophyte emerges to the dorsal face by an oblique collar, straight in $R$ purpurascens. (3) spore ornamentations. 

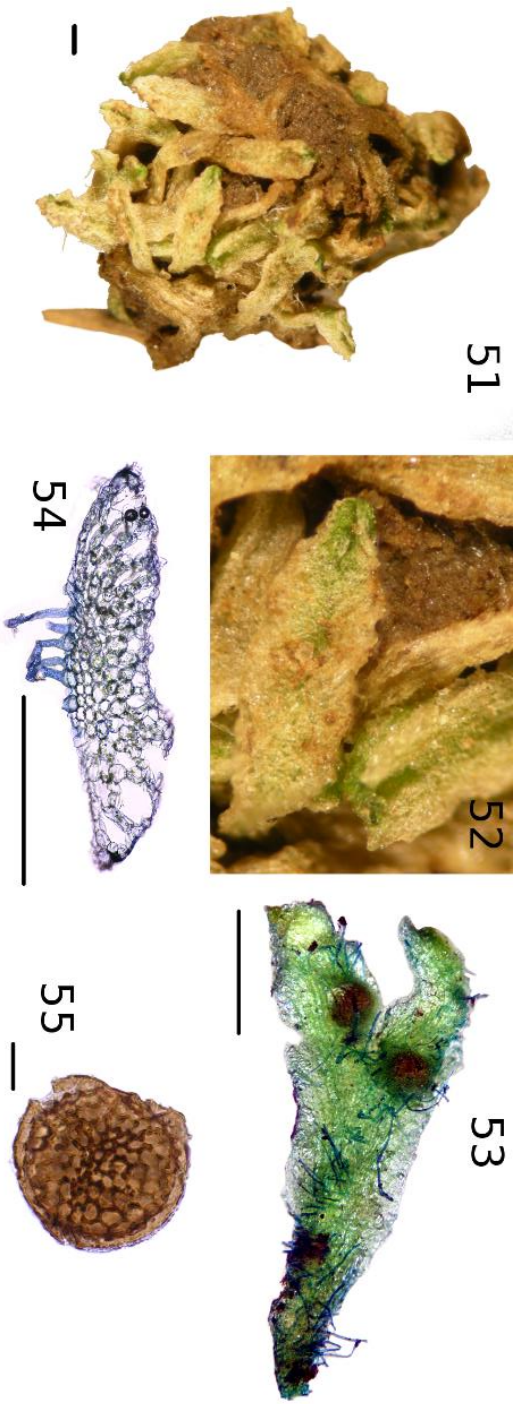

Figures 51-55. Riccia purpurascens Lehm. \& Lindenb.. (51) Rehydrated thalli, Makirovana, Reeb CR203. Scale bar 1 mm (52) Details, Reeb CR203 (53) Ventral face. Scale bar $1 \mathrm{~mm}$. (54) Cross section. Scale bar $500 \mu \mathrm{m}$. (55) Spore, distal face. Scale bar 10 $\mu \mathrm{m}$. 
Riccia stricta* (Lindenb.) Perold. Bothalia 20: 197. 1990.

Type: SOUTH-AFRICA, Cape, Philipstown, ad arborum truncos, Ecklon s.n. (BM) Basionyme: Riccia fluitans var. stricta Gottsche et al. Synopsis Hepaticarium 4: 610. 1846. Thallus strap like, green, branches furcate (Figure 56), up to $20 \mathrm{~mm}$ long, less than $1.2 \mathrm{~mm}$ wide, apex rounded and often thickened to bulbous, often slightly tapering and narrower than following segment (Figures 56, 57); distinct areolation materializing limits of air chambers visible or not on the dorsal face, often at the apical segment (Figures 57, 62). Ventral scales present at the apical zone, not protruding, single rounded to triangular, often divided but remaining joined at basis (Figure 59). Monoicous. Sexual reproduction very frequent, gametangia not seen. Sporophyte protruding on ventral face (Figure 58). Spores orange-brown to light brown, semi-translucent (not opaque), triangular globular, wing obvious 4-8 $\mu$ m wide, (50-)60$80 \mu \mathrm{m}$ diameter; 5-6 complete alveoli in distal face; triradiate mark obvious on proximal face, each facet with 6-10 alveoli complete or not; (Figures 60, 61, 63-66).

Distribution: from North to South, 0-1200 m (Figure 80). Occurs in Sub-Saharan Africa (Perold 1999), India (Manju et al. 2012) and probably also in North America (Schuster 1992).

Ecology: in freshwater, running or stagnant, or on banks, close to the river for terrestrial form.

Since 1836 this species has been considered as a variety of R. fluitans, $R$. fluitans var. stricta (Lindenberg 1836). Jones (1957) observed that the spores of African's specimens are different from the European ones. Perold (1990) proposed a new combination $R$. stricta (Lindenb.) Perold. This species appears also to be close to $R$. stenophylla Spr. (Schuster 1992). She argued that all the African collections of the difficult and very variable group of $R$. fluitans that she studied were indeed $R$. stricta. We have found in Jovet-Ast's archive documents of her study of Onraedt 14M2023 (Figure $16 \mathrm{H}$ $K$ ) that the spores by SEM show the same ornamentation as described by Perold (1990). 

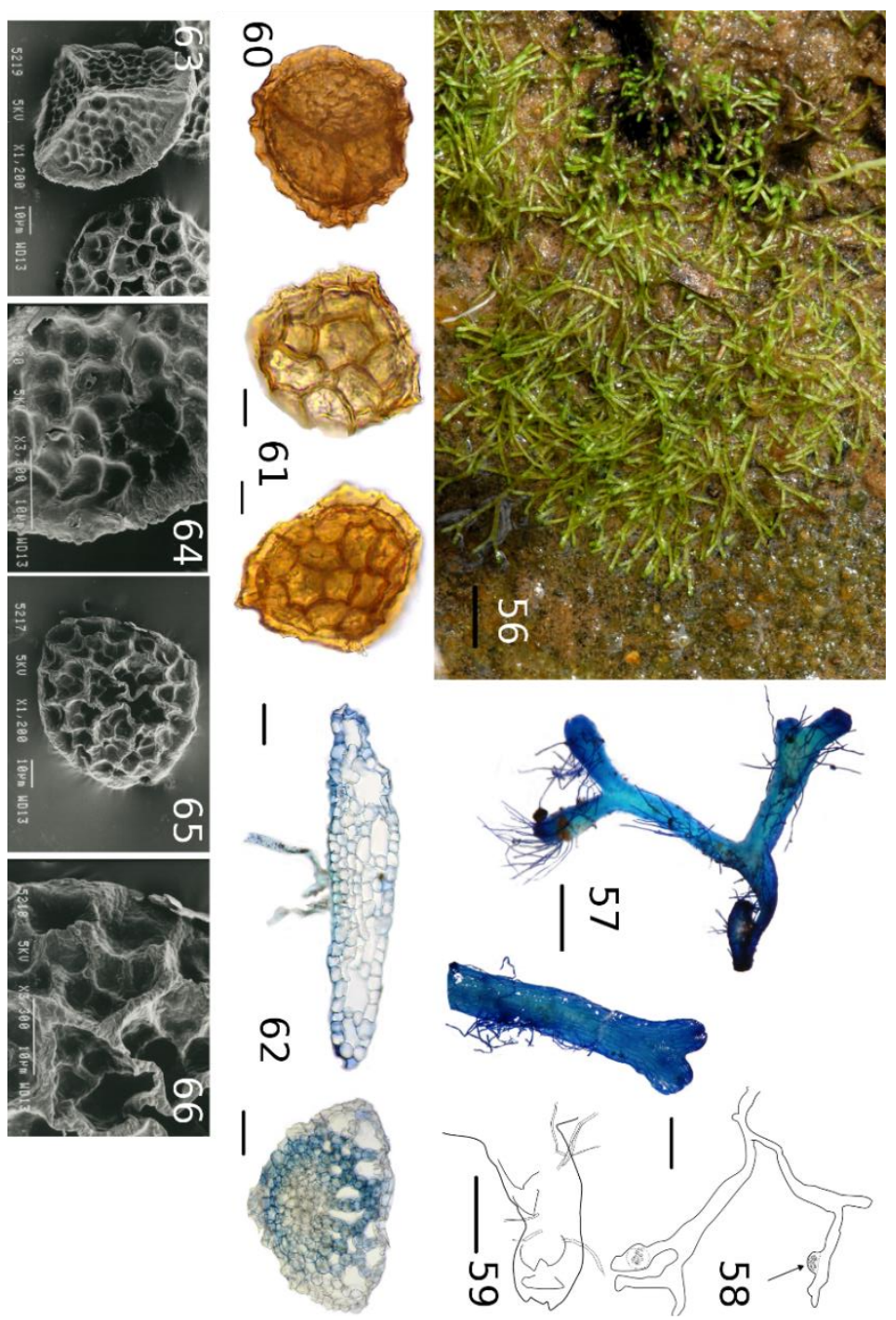

Figures 56-66. Riccia stricta (Lindenb.) Perold. (56) On the field along the banks of a small stream, Makay Massif, Reeb CR1144. Scale bar $1 \mathrm{~cm}$. (57) Thallus ventral (left) and dorsal (right) face. Coloration with bleached (20\%), rinses and diluted methylen blue. (58) Bulging sporophyte in lateral view. (59) Ventral view with scales. Scale bars $1 \mathrm{~mm}$. (60) Spore proximal face. (61) Spore distal face. Optical microscopy, scale bars $10 \mu \mathrm{m}$. (62) Cross section old branch (left), terminal branch (right). Coloration with bleached (20\%), rinses and diluted methylen blue. (63) (64) Spore proximal face. (65) (66) Spore distal face, Onraedt 14M2023, scanning electronic microscopy by Mme Jovet-Ast, 1994. 
The main characters that differentiate the two species are: (1) apex narrowed in $R$. stricta; (2) frequent presence of sporophyte in $R$ stricta compared to $R$. fluitans. These species appear to be also close to R. stenophylla Spr. (Schuster 1992), but the R. stricta spore ornamentation shows large, very thick and deep walled alveoli and is different from both those of $R$. fluitans and $R$. stenophylla.

Specimen examined: ANTANANARIVO, Antananarivo, sur la terre près des serres du parc de Tsimbazaza, elev. $1250 \mathrm{~m}, 06 / 08 / 1973$, Cremers 2409 (PC-PC0738825, PC0715990, TAN); Cremers 2415 (PC); Antananarivo, Tourbière de Tsimbazaza, 1250 m, 06/08/1973, Cremers 2417 (TAN); route d'Antsirabe, $11 \mathrm{~km}$ environ d'Antananarivo, rizières après la récolte, 14/07/1951, Benoist (PC); Antananarivo, Jard. Bot. de Tsimbazaza, elev. 1400 m, 28/02/1974, Onraedt 14M2023, (PC-PC0715988); In montibus Ankaratra 1877, M. Borgen 110 (PC-PC0715999); Environs d'Antananarivo, PK 22 route d'Antananarivo, Sept. 1959, Bosser 13262 (PC-PC0715992, TAN); ANTSIRANANA, forêt d'Anjahana, au sud-est d'Ambilobe, dans le lit du fleuve Antsiatsia, 28/08/1973, Cremers 2686 (PC). FIANARANTSOA, Forêts de Ranomafana, $60 \mathrm{~km}$ au Nord de Fianarantsoa, elev. 900 m, 16/08/1971, Onraedt 71 M5045 (PCPC0715989); Andringitra, Mts near Ambalavao, elev. $1012 \mathrm{~m}$, 21ํ5'S 4565'E, 20/09/1994, S. Orbán 9459/B (EGR, PCPC0716003); Fianarantsoa, Parc National de Ranomafana, S. slope of

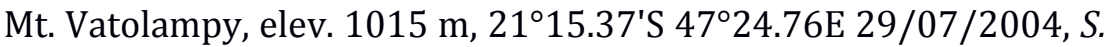
\& T. Pócs 04127/C (EGR, PC-PC00716001); Ranomafana National Park 1km W from Ambatolahy, elev. $1015 \mathrm{~m}, 2^{\circ} 15^{\prime} 19^{\prime \prime} \mathrm{S}$ 47²4'48”E, 27/09/1994, S. Orbán 9466/C (EGR, PC-PC0716002). TOAMASINA, Pays des Antsianaka [Antsihanaka], leg. Perrot 1890 (PCPC0715898); Pays des Antsianaka [Antsihanaka], Mars1891 leg. Perrot (PC-PC0716000); route de Tamatave [Toamasina], $11 \mathrm{~km}$ est de Manjakandriana (Ambatoloana), elev. 1300 m, 09/1962, Bosser 16201 (PC). TOLIARA, au bord du Fiherenana, près de Miary, elev. 200 m, 30/06/1971, Onraedt 71M5526 (PC); Makay, le long de la rivière Ambotorabatorano, sur grès $21^{\circ} 34^{\prime} 04.9 \mathrm{~S} \quad 45^{\circ} 04^{\prime} 33.7 \mathrm{E} 303 \mathrm{~m}$ 01/04/2011 CR1144 (TAN-PC).

Species to be confirmed: Riccia perssonii S.A. Kahn is cited for Madagascar (Marline et al .2012), and was first identified by Perold 
(1995b), but without any specimen reference. The spores of this heterothallic species are in tetrads, which is a rare character state in Riccia. But we could not see or collect specimens of this species.

\section{TARGIONIACEAE}

Targionia hypophylla L. Species Plantarum 2: 1136. 1753.

Type: 'Italia, Hispania, Constantinopoli' + citation (syn.); Dill.: 532. Lichen No. 9, tab. 78, fig. 9. (1741) (OXF, syn.); (H-SOL, isosyntype) [according to Isov. (1970) and quoted by Grolle (1976)]. Synonymes: Targionia michelii Corda. Naturalientausch 12: 649. 1829. Type: Italy, leg. Sieber.Targionia mexicana Lehm. \& Lindenb. Nov. Stirp. Pug. 4: 27-28. 1832. Type: Mexico, leg. Schiede. Targionia capensis Huebener. Hep. Germ. 17. 1834. Targionia bifurca Nees \& Mont. Ann. Sci. Nat., Bot., ser. 2, 9: 40 \& 113. 1838. Type: Chile, 'prope Quillota', leg. Brotero. Targionia convoluta Lindenb. \& Gott. Syn. Hep. 576. 1846. Type: Mexico, ad Chinantla, leg. Liebman.

Thalli in crowded patches of strap-like and simple branches (not in rosettes) (Figures 67, 68), cordate when young up to $3 \mathrm{~mm}$ wide, fleshy to leathery, dark green, without groove, margin often purple; when dry, the margins are inrolled letting the ventral scales cover all the thallus. Air pores visible. Ventral scales in two rows reaching the margins, shiny purple-black (Figures 67, 69). Dioicous or autoicous. Antheridia terminal or lateral on branches which arise ventrally. Archegonia in ventral position just below the apex of the branches, protected by a black shiny involucre, opening by a longitudinal and central fissure. Sporophyte sub-sessile with globose capsules. "When dry the apical portion of thalli bearing the sporophytes bends upward away from the substratum and the valves of the involucre gape apart like a mussel" (Jones 2004). Spores light brown to reddish brown, 44-64(-77) $\mu \mathrm{m}$; distal face with alveoli limited by thick walls, bottom of the alveolus covered by smaller and thinner reticulation (Figure 70).

Distribution: known from around Antananarivo and in central plateau (Figure 78). Sub-cosmolitan.

Ecology: on temporary humid banks, or compact banks. All the specimens examined were assigned to T. hypophylla, although 
another species, Targionia lorbeeriana Müll.Frib. was cited for Africa (Arnell 1963). This last species is a triploid of T. hyphophylla (Zamora et al. 1990). After examining numerous South African specimens and the type specimen of T. lorbeeriana, Perold stated that all the studied African collections were T. hypophylla. The distinction of the two species can be done on thallus and cells dimensions and on spore ornamentation (Jovet-Ast and Zigliara 1966). Malagasy specimens match the T. hypophylla description.

Specimen examined: ANTANANARIVO, Tananarive, 03/1914, talus, Waterlot 94 (PC- PC0716010), Waterlot 97 (PC- PC0716009); Andramasina (Ambatolampy), vestige de forêt d'altitude, $1300 \mathrm{~m}$, déc. 1958, Bosser 12324 (PC-PC0716008); Fort-Voyron, 19/01/1921, Decary s.n. (PC- PC0716011); Antananarivo, 13/02/1921, Decary s.n. (PC-PC0716013, PC0716014); Forêt d'Angavokely, alt 1603 m, S 1855'24.9 E 47²4'21.7, 02/02/2011, Reeb \& Andriamiarisoa CR11185 (PC, TAN). FIANARANTSOA, Ankafotra (Ambafiandrohana) 1700 m, 16/02/1938, Decary s.n. (PCPC0716012). 

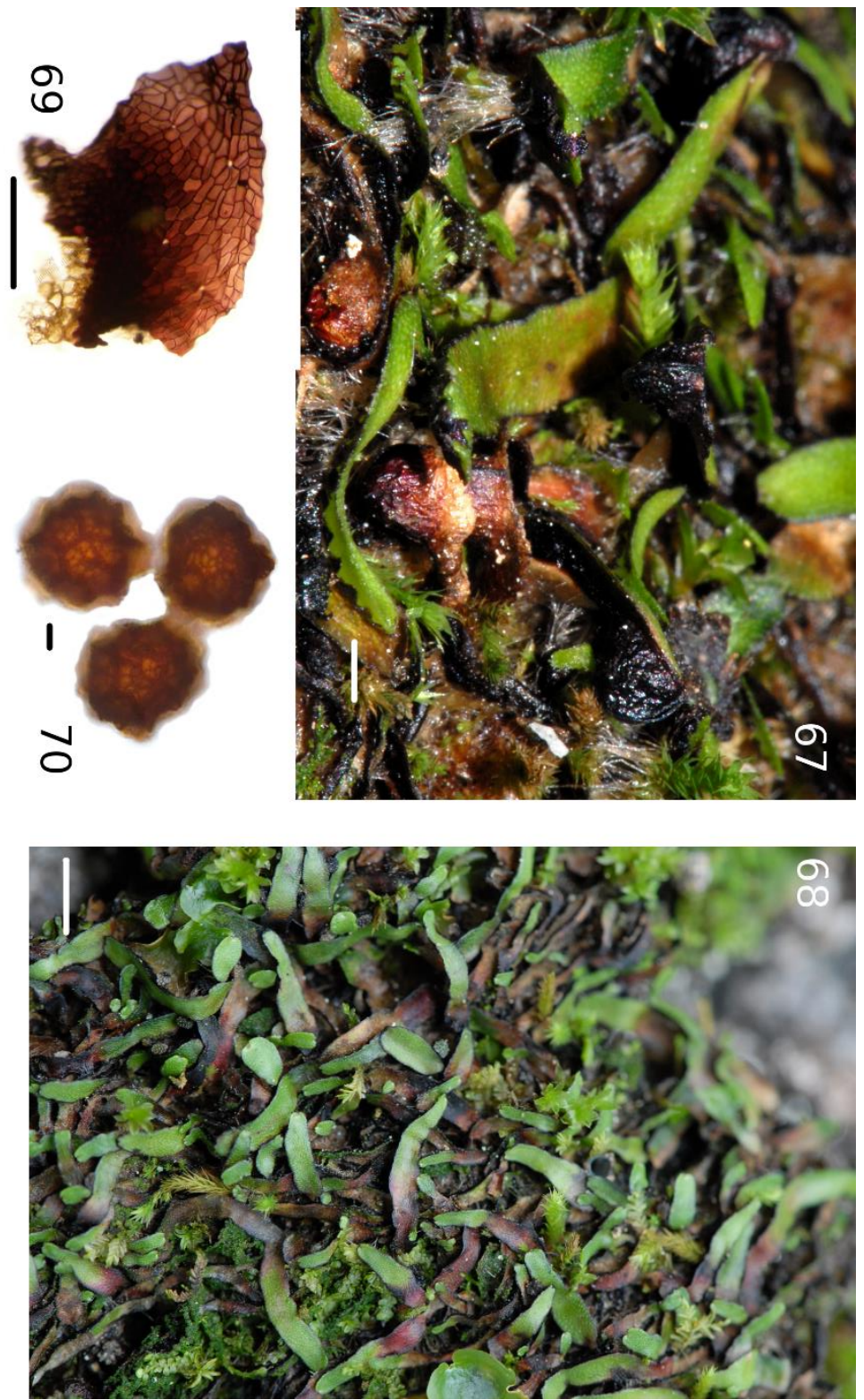

Figures 67-70. Targionia hypophylla L. (67) Population, showing the mussel-like ventral valvae enclosing the sporophyte. Scale bar $1 \mathrm{~mm}$. (68) Scale bar $5 \mathrm{~mm}$ (69) Scale bar 500 $\mu \mathrm{m}$. (70) Scale bar $10 \mu \mathrm{m}$. Angavokely, Reeb \& Andriamiarisoa, CR111855. 


\section{CONCLUSIONS}

Six new records of Marchantiidae are proposed for Madagascar: Asterella bachmanii (Steph.) S.W.Arnell. (as synonym of A. coronata Steph.), Asterella marginata (Nees) S.W.Arnell, Exormotheca pustulosa Mitt., Riccia congoana Steph., Riccia atropurpurea Sim. and Riccia stricta (Lindenb.) Perold. Two cited species are not recognized here: (1) Asterella wilmsii, which is probably misidentified and assigned here to A. marginata, (2) Riccia perssonii, which was not seen in the collections and with no voucher references (Perold 1995).

No endemic Marchantiidae were discovered in Madagascar, and the synonymy of A. coronata could be seen as a confirmation of the relatively low level of endemism of bryophytes lineages and the need of further revisions including molecular studies (Vanderpoorten et al. 2010). We make the assumption than new records or new species could be discovered in the genus Riccia, where several specimens could not be identified using the available literature. One can notice that the Lunularia genus common in East Africa has not been cited before for Madagascar and was not recorded in the studied collections.

Morphological observations highlight the necessity of extensive studies to clarify or confirm the status of several taxa in order to assess their whole variability. An integrative approach combining molecular analysis and morphometry etc. should be one way to evaluate species delimitations in Malagasy and African related taxa. Although taxonomic work was achieved for Eurasian and American species, similar studies on African Asterella are awaiting (Long 2006). The same effort must be done for Riccia, especially for the fluitans group to clarify species. Some species are known only by a few specimens and collection effort in potentially favorable environments and seasons has to be conducted to enlarge the knowledge; this is the case of Cyathodium africanum, Targionia hypohylla and Plagiochasma microcephalum.

In our study, fifteen species of Marchantiidae are reported for Madagascar; fifteen species are also known for La Réunion, 230 times smaller than Madagascar (Ah-Peng and Bardat 2005). If we 
refer to the largest genus, Riccia (Ricciaceae), four species are cited for La Réunion, sixty-six for South Africa (Wigginton 2009) compared to only six (seven, if Riccia perssonii could be confirmed) species known in Madagascar. It is reasonable to hypothesize that Madagascar is understudied, especially for the complex thalloid species.

During our recent field trips in Madagascar, it seemed difficult to see Marchantiidae in a priori favourable environments (road banks, high plateau steppes etc.), except in the Makay Massif where abundant Ricciaceae were found. We suggest that these plants living in open areas are probably under a great fire pressure mainly due to the pratice of traditional tavy (slush and burn) culture (Figures 71, 72). Some species are known to be fire resistant and to appear as primitive colonizer after fire (Esposito et al. 1999). But repeated fire has not the same effect than occasional ones, and in numerous places the soil is bare, missing bryophytes on a degraded laterite substratum repeatedly burn. Further exploration of stations cited by former collectors or of favourable stations could test that hypothesis. Experimentation on thalloid liverworts resistance to fire could also help to understand their strategies and adaptations in such context.

\section{Participation of the different authors}

Catherine Reeb collected plants in Madagascar, identified and described specimens, wrote and illustrated the paper. Lovanomenjanahary Marline collected specimens in Madagascar and contributed to the writing of the whole publication. Lucile Rabeau collected plants in Madagascar and contributed to the writing on the Ricciaceae. Ainazo Andriamanantena collected plants in Madagascar, gathered historical references, identified and described specimens; this study was initiated in the context of her master thesis in 2010. Roger Lala Andriamiarisoa organized Angavokely fieldtrip, collected specimens all around Madagascar and provided drawings. Hery-Lisy Ranarijaona, supervised the project and reviewed the publication for Malagasy vegetation. Tamás Pócs collected specimens and gave his expertise and corrections for the publication. 


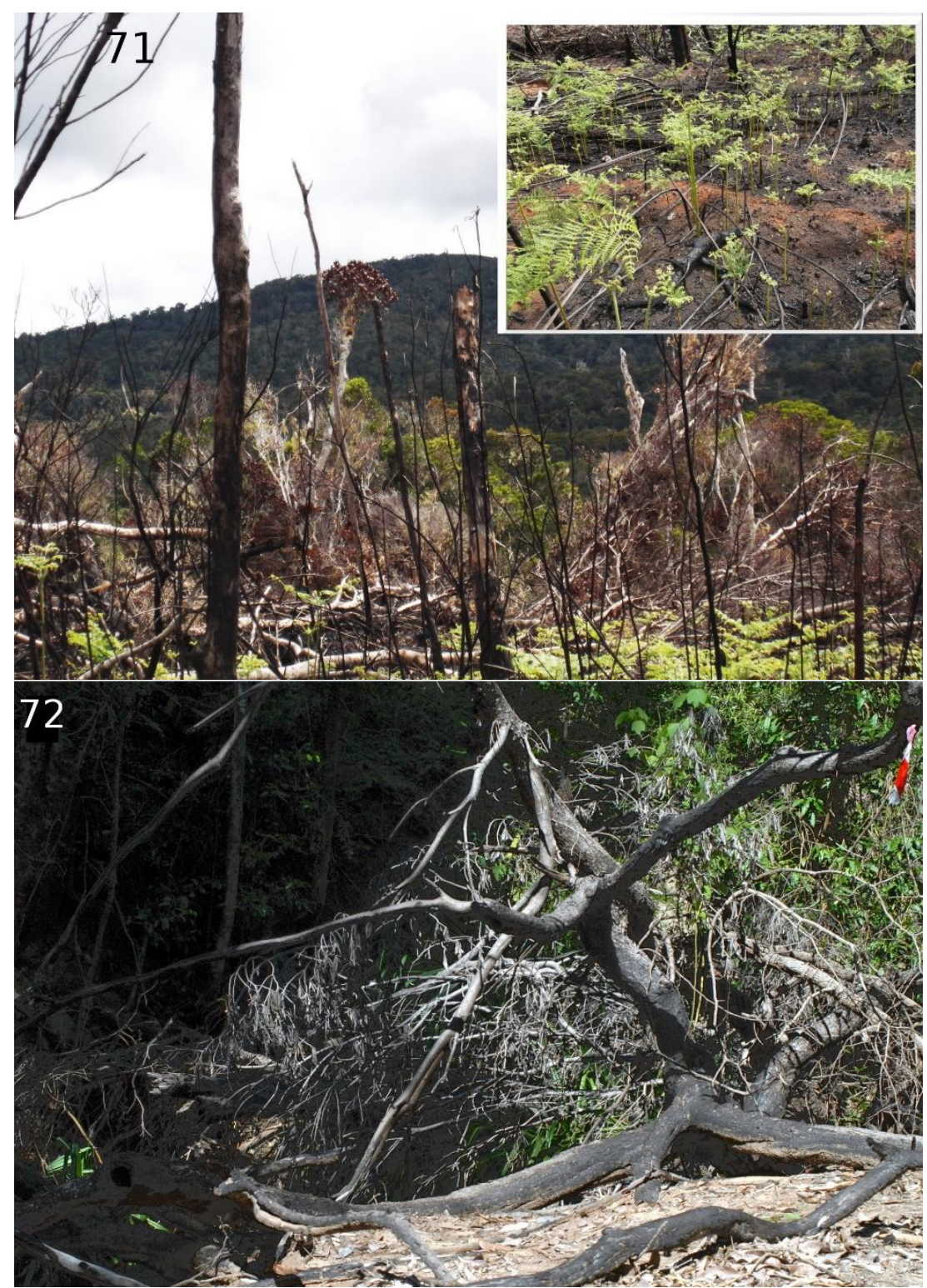

Figures 71-72. Fire and deforestation. (71) In Zahamena National Parc, 2015. Details of the soil show the potential impact on bryophytes. (72) In the Makay massif, 2011, on a river bank, a very favorable station for Marchantia and Riccia. 


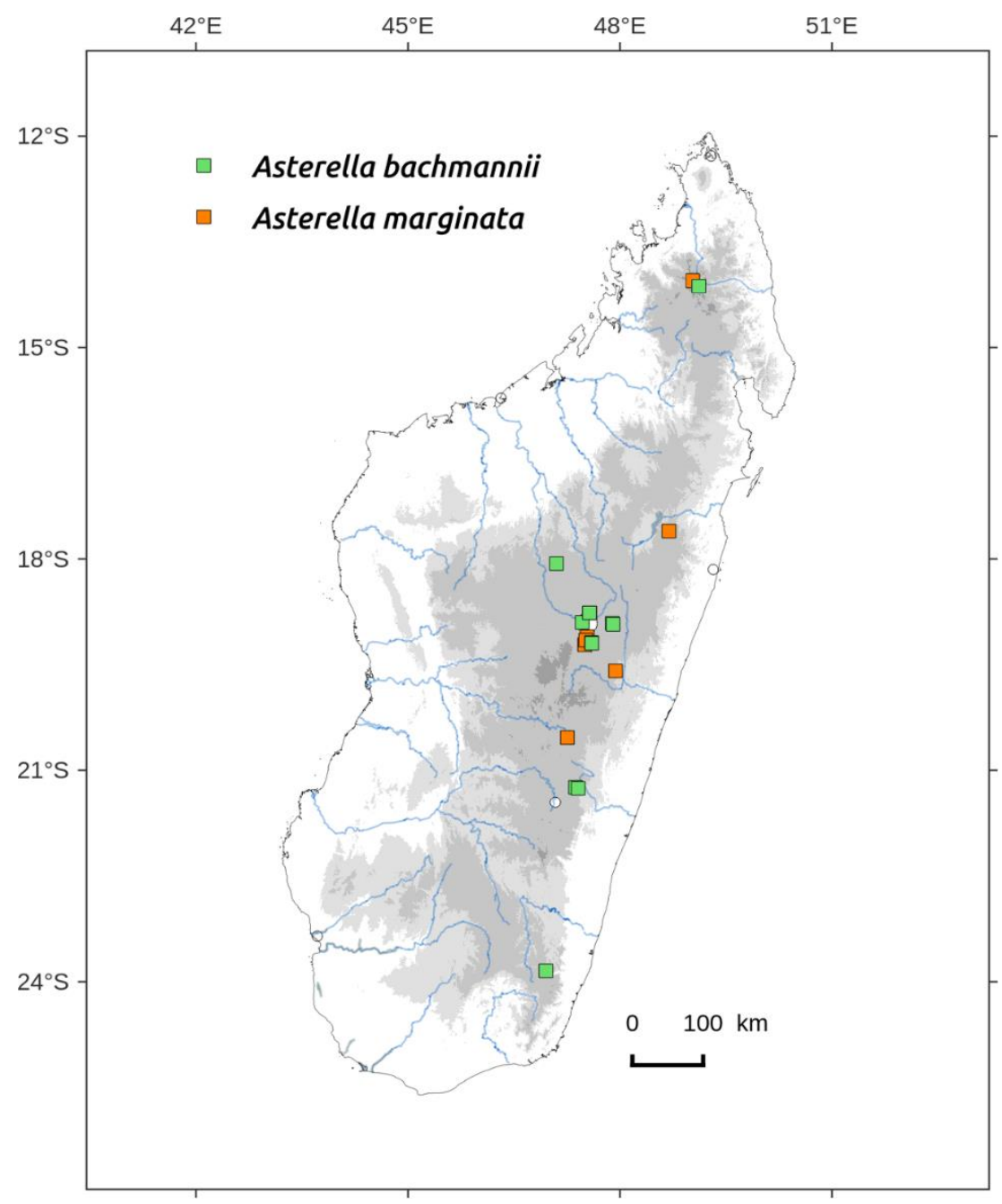

Figure 73. Distribution map of Asterella bachmanii and Asterella marginata in Madagascar, based on the specimens studied from EGR, PC and TAN herbarium and the authors' collections. 


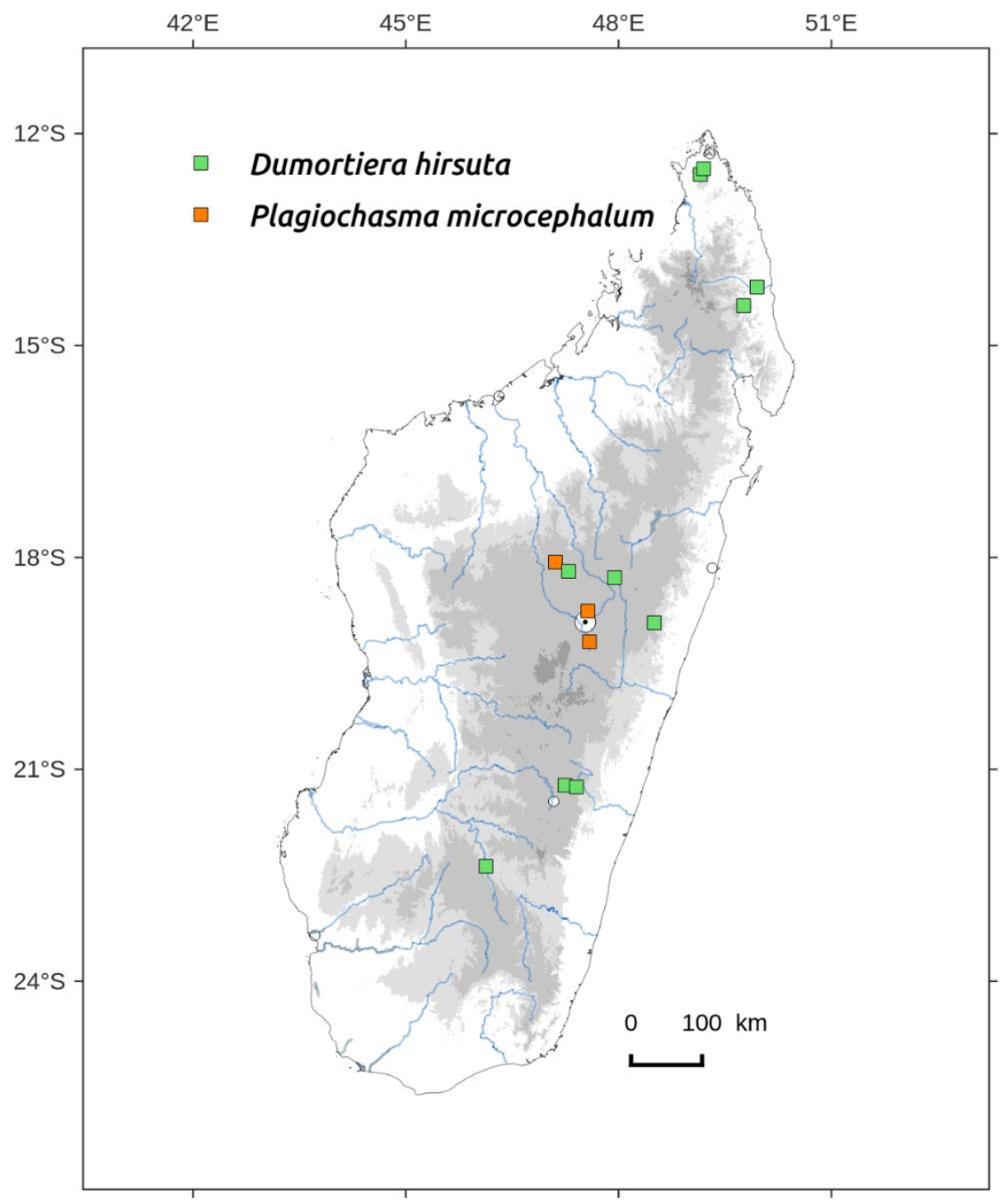

Figure 74. Distribution map of Dumortiera hirsuta and Plagiochasma microcephalum in Madagascar, based on the specimens studied from EGR, PC and TAN herbarium and the authors' collections. 


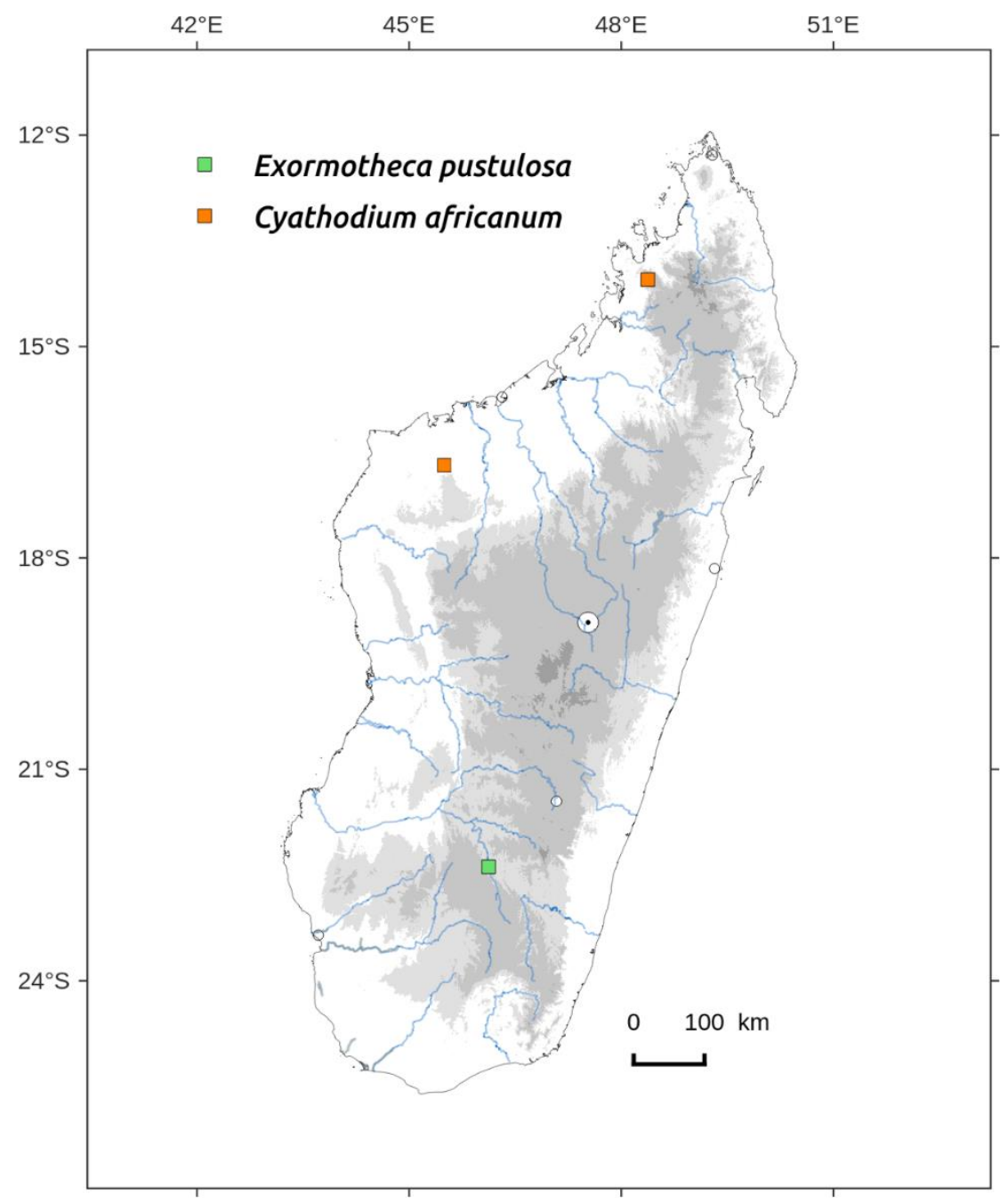

Figure 75. Distribution map of Exormotheca pustulosa and Cyathodium africanum in Madagascar, based on the specimens studied from EGR, PC and TAN herbarium and the authors' collections. 


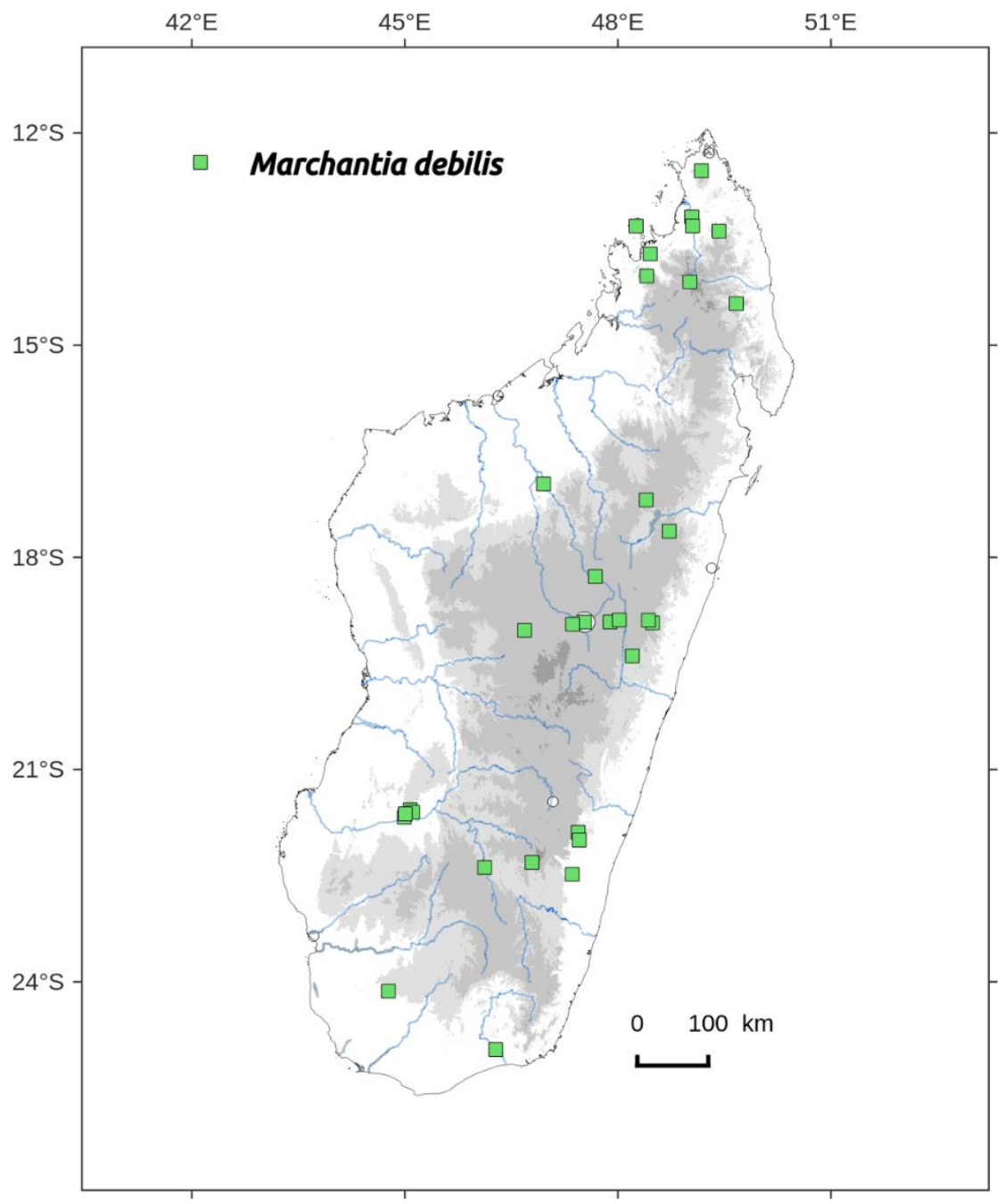

Figure 76. Distribution map of Marchantia debilis in Madagascar, based on the specimens studied from EGR, PC and TAN herbarium and the authors' collections. 


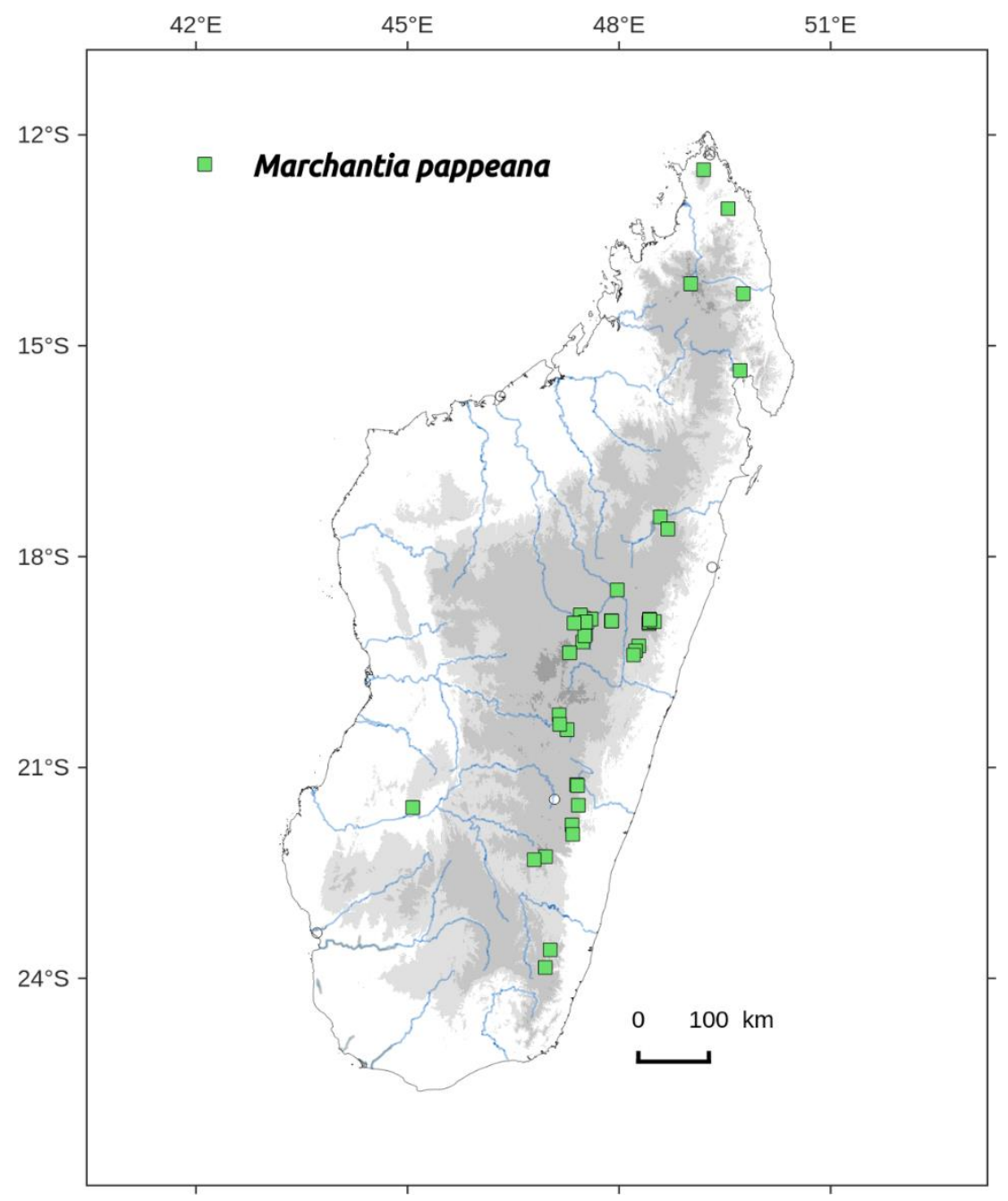

Figure 77. Distribution map of Marchantia pappeana in Madagascar, based on the specimens studied from EGR, PC and TAN herbarium and the authors' collections. 


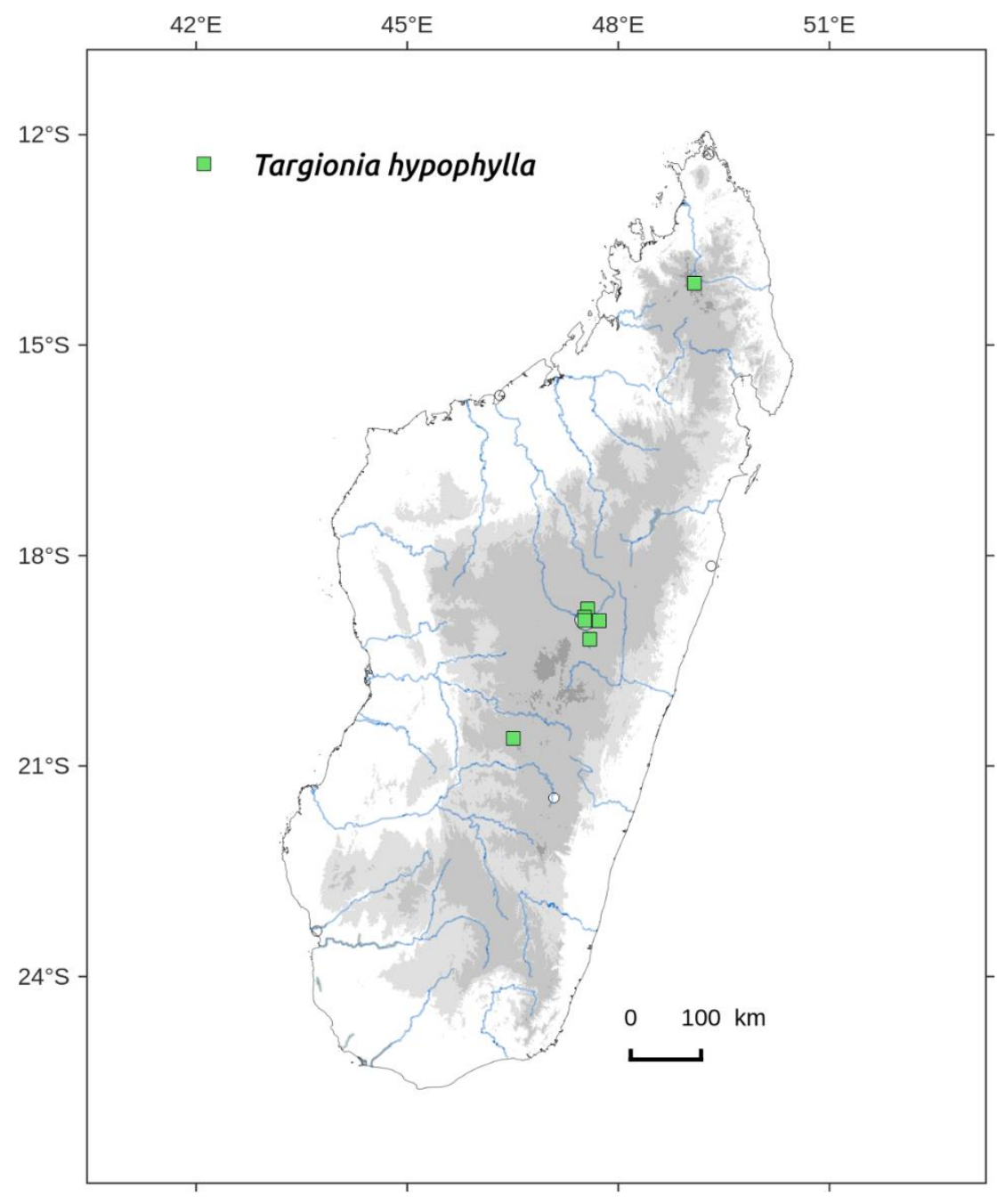

Figure 78. Distribution map of Targionia hypophylla in Madagascar, based on the specimens studied from EGR, PC and TAN herbarium and the authors' collections. 


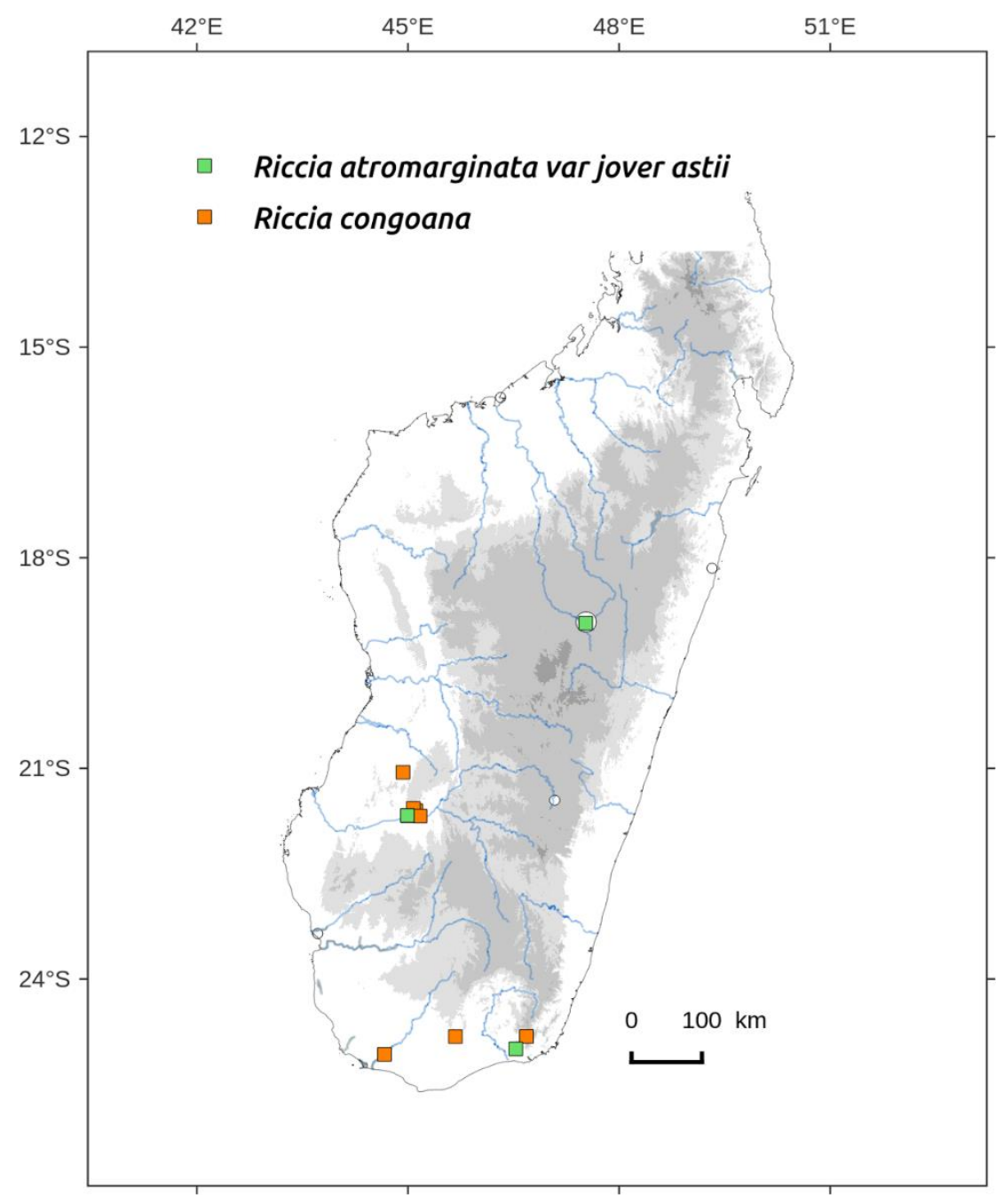

Figure 79. Distribution map of Riccia atromarginata var. jovet-astii and Riccia congoana in Madagascar, based on the specimens studied from EGR, PC and TAN herbarium and the authors' collections. 


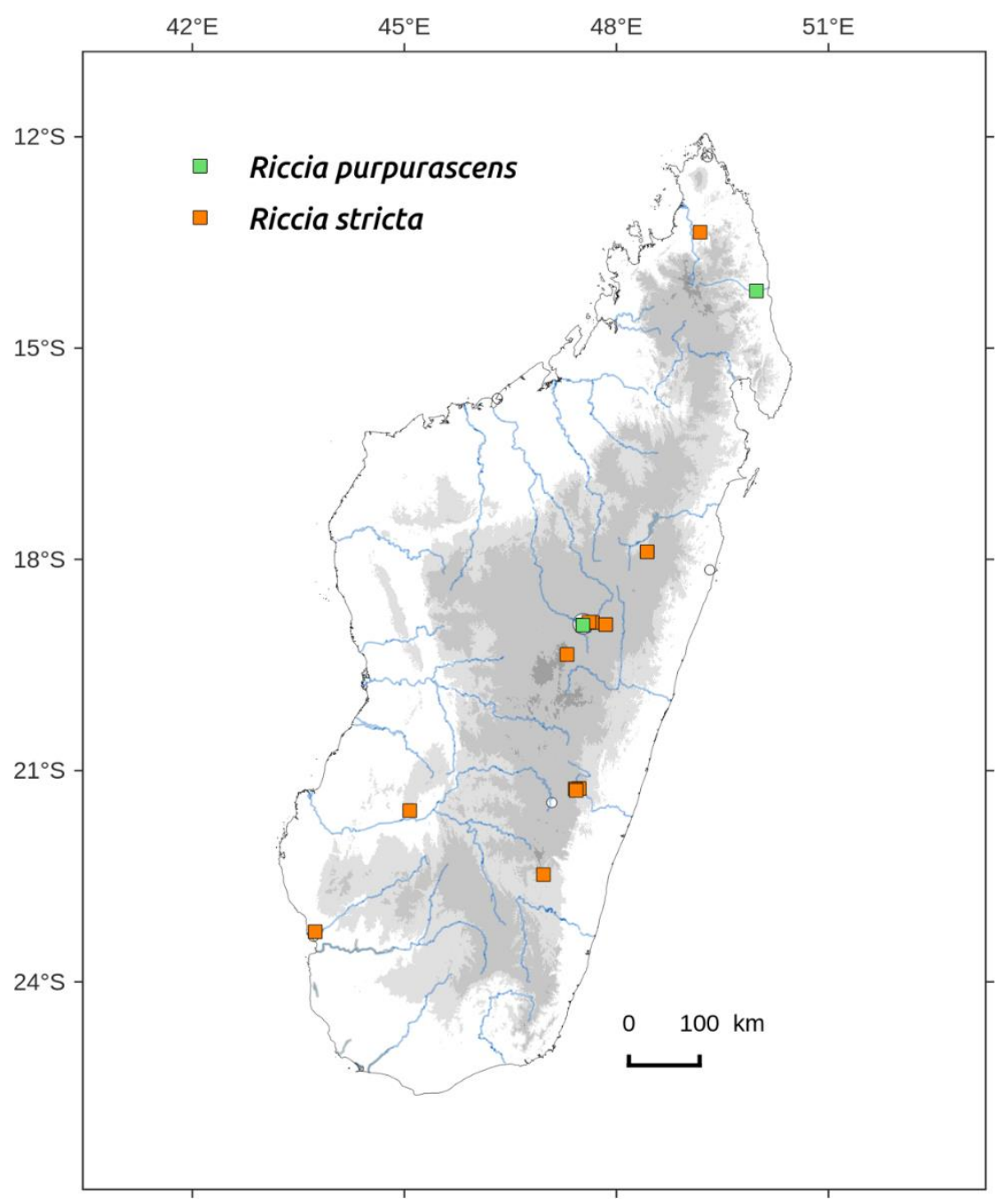

Figure 80. Distribution map of Riccia purpurascens and Riccia stricta in Madagascar, based on the specimens studied from EGR, PC and TAN herbarium and the authors' collections. 


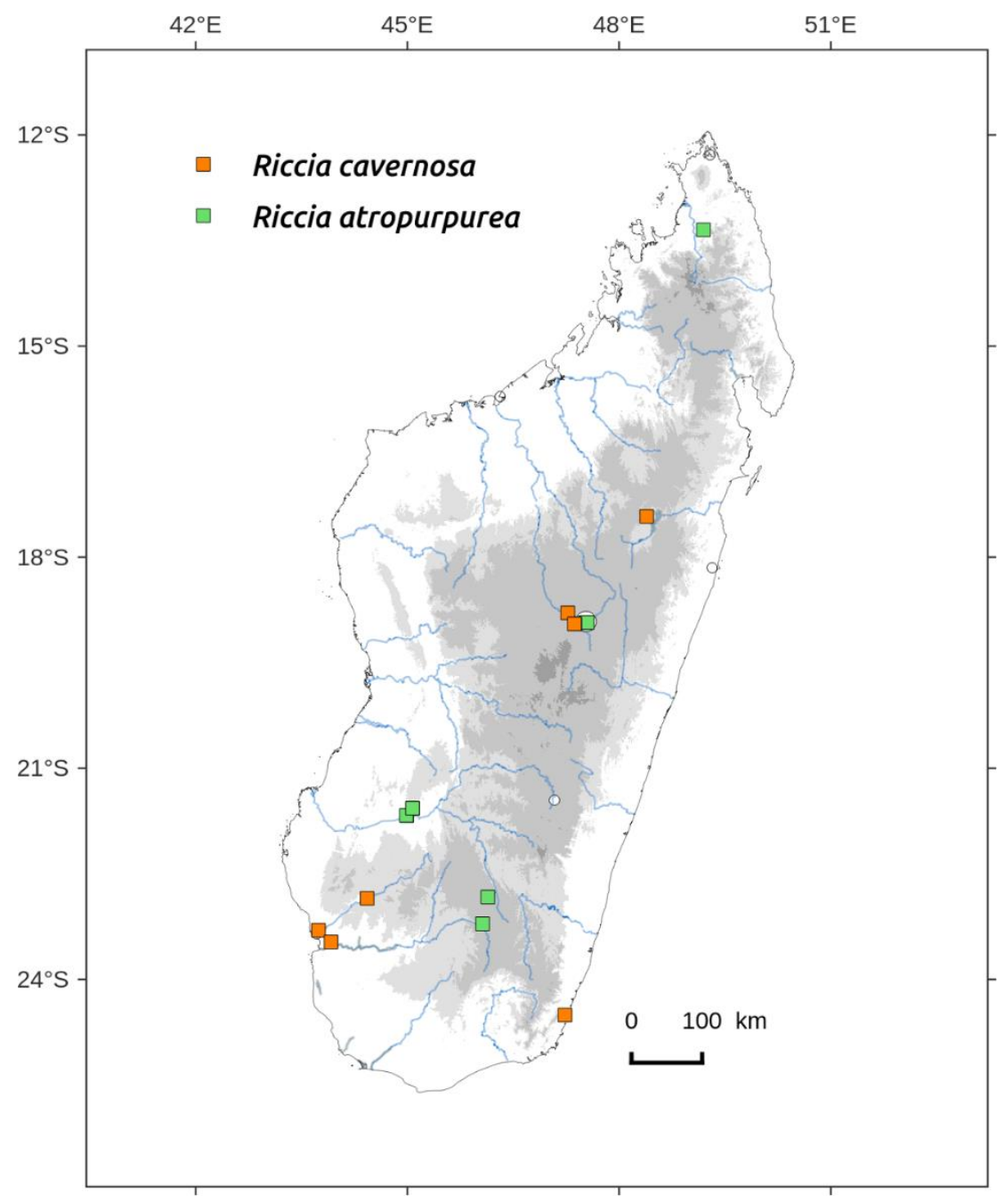

Figure 81. Distribution map of Riccia cavernosa and Riccia atropurpurea in Madagascar, based on the specimens studied from EGR, PC and TAN herbarium and the authors' collections. 


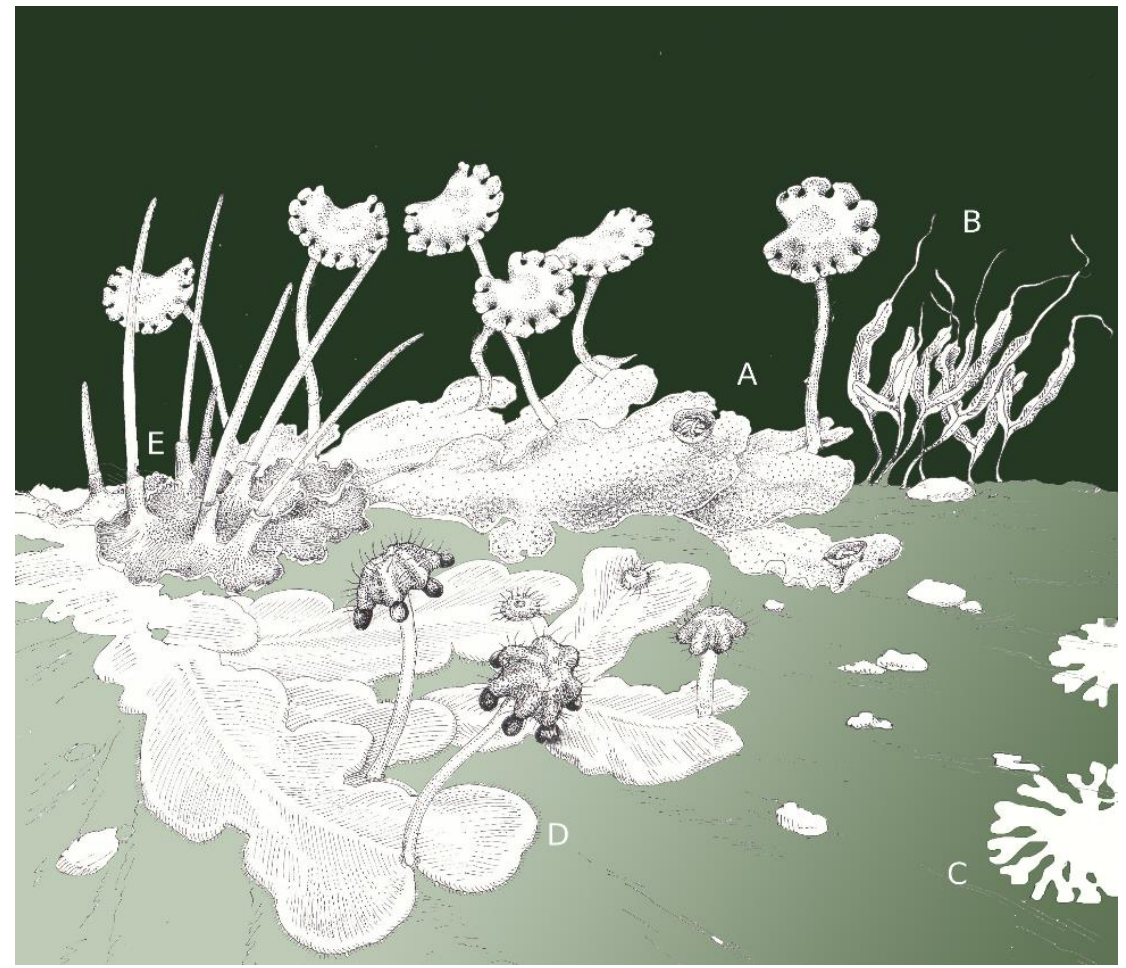

Figure 82. Artistic representation of thalloid bryophytes taxa from Madagascar. Marchantiales (complex thalloid): A = Marchantia pappeana, B = Symphyogyna podophylla, (simple thalloid) C = Riccia sp. Pallaviciniaceae D = Dumortiera hirsuta, recently reported for Madagascar (Andriamiarisoa et al., 2017). $\mathrm{E}=$ Anthocerotophyta. Drawings made by Roger Lala Andriamiarisoa. 
Acknowledgments - The authors wish to thank: TAN herbarium, EGR herbarium and PC herbarium for the facilities for studying specimens. Madagascar National Park who provided authorizations to collect bryophytes in numerous areas: Vohimana, Maromizaha (GERP/SG/OUT/12/0020), Angavokely $\left(\mathrm{N}^{\circ} 030 / 11 / \mathrm{MEF} / \mathrm{SG} / \mathrm{DGF} / \mathrm{DCB} . \quad \mathrm{SAP} / \mathrm{SCB} \quad 31 / 01 / 2011\right), \quad$ Makay $\left(\mathrm{N}^{\circ} 360 / 10 / \mathrm{MEF} / \mathrm{SG} / \mathrm{DGF} / \mathrm{DCB} . \mathrm{SAP} /\right.$ SLRSE 28/12/2010), Makirovana (MBG collection authorization), Zahamena (N²75/13/MEF/SG/DGF/ DCB.SAP:SCB 14/11/2013). ONG "L'Homme et l'Environnement" who allowed Vohimana prospections. "Association Timarcha", Campus Jussieu, UMPC, Paris, France who supported and funded 2006 and 2012 fieldtrips and collection. Thanks to the GERP and Pr. Jonah RATSIMBAZAFY for facilitating our visit of Maromizaha reserve. MBG (Missouri Botanical Garden) and Chris Birkenshaw who organized in the Makirovana fieldtrip, and Angavokely fieldtrip. Naturevolution and Evrard Wendenbaum for organizing the Makay fieldtrip and invited some of the authors to this adventure.

Thanks to PARRUR funding (PArtenariat et Recherche dans le secteur RURal) of the french IRD in Madagascar to give a grant for Zahamena field trip, to the co-author Andriamanantena.

Thanks to all the Malagasy people who helped the success of the different fieldtrips (carriers, cooks, drivers...), especially LeSabotsy in Ambavaniasy, réserve de Vohimana. Thanks to David Long for advices on Asterella.

\section{REFERENCES}

Ah-Peng, C. \& Bardat, J. (2005). Check list of the Bryophytes of Réunion Island (France). Tropical Bryology 26: 89-118. https://doi.org/10.11646/bde.26.1.14 AndriamiarisoA, R., Callaghan, D. A. \& ReEb, C. (2017). in: Ellis, L.T. et al.: New national and regional bryophyte records, 53. Journal of Bryology. 39(4): 379380. https://doi.org/10.1080/03736687.2017.1384204

ARnell, S. (1963). Hepaticae of South Africa. Swedish Natural Science Research Council, Stockholm. 411 pp.

Bescherelle, E. (1880). Florule bryologique de l'île de Nossi-Bé. Revue Bryologique 7: $1-14$.

BESCHERELLE, E. (1891). Selectio novorum muscorum. Journal de botanique (Morot) 5(9): 142-148.

BISCHLER, H. (1976). Exormotheca pustulosa Mitten. Distribution, écologie, caryotype, spores, parois sporales, germinations. Revue Bryologique et Lichénologique 42: 769-783.

BischleR, H. (1978). Plagiochasma Lehm. \& Lindenb. II. Les taxa européens et africains. Revue Bryologique et Lichénologique 44: 223-230.

BischleR, H. (1993). Marchantia L. The European and African taxa. Bryophytorum Bibliotheca 45: 1-129.

BisCHLER, H. (1998). Systematics and evolution of the genera of Marchantiales. Bryophytorum Bibliotheca 51: 1-152 + 24 plates.

Bischler-Causse, H., Gradstein, S.R., Jovet-Ast, S., Long, D.G. \& Salazar Allen, N. (2005). Marchantiidae. Flora Neotropica Monograph 97: 1-267.

Boisselier-Dubayle, M.-C., LAmbourdière, J. \& Bischler, H. (2002). Molecular phylogenies support multiple morphological reductions in the liverwort 
subclass Marchantiidae (Bryophyta). Molecular Phylogenetics and Evolution 24: 66-77.

Boiteau, P., Boiteau, M. \& Allorge-Boiteau, L. (1997). Index des noms scientifiques avec leurs équivalents malgaches. Ed Alzieu, Grenoble, France. (non-paginated)

Снuaн-Ретіот, М. (2003). Mosses, liverworts and hornworts from Kenya. Nairobi, 273 pp.

Connet, A. (1974). Essai de cartographie bioclimatique à Madagascar. Orstom Publishers, Paris, 28 pp.

Cornet, A. \& Gulllaumet, J. (1976). Divisions floristiques et étages de végétation à Madagascar. Cahiers de l'Orstom, Série Biologie 9: 35-42.

Crandall-Stotler, B., Crandall-Stotler. R. \& Long, D. (2009). Phylogeny and classification of the Marchantiophyta. Edinburgh Journal of Botany 66: 155-198. https://doi.org/10.1017/S0960428609005393

DolCH, R. (2009). Andasibe (Périnet), les efforts actuellement entrepris sont-ils suffisants pour protéger la nature du hot-spot de biodiversité à Madagascar? In: Goodman, S. (ed.): Paysages naturels et biodiversité de Madagascar. Publications scientifiques du Muséum, Paris, pp. 547-557.

DorR, L. (1997). Plant Collectors in Madagascar and the Comoro Islands. The Trustees Royal Botanical Garden Kew, 524 pp.

DuCKetT, J. \& Ligrone, R. (2006). Cyathodium Kunze (Cyathodiaceae: Marchantiales), a tropical liverwort genus and family new to Europe, in Southern Italy. Journal of Bryology 25: 88-96. https://doi.org/10.1179/174328206X105353

Esposito, A., Mazzoleni S. \& Strumia, S. (1999). Post-fire bryophyte dynamics in Mediterranean vegetation. Journal of Vegetation Science 10: 261-268. https://doi.org/10.2307/3237147

Faramalala, M. (1995). Formations végétales et domaine forestier national de Madagascar. 1 : 1.000 .000 color map. Direction des Eaux et Forêts (DEF), centre National de Recherches sur l'Environnement (CNRE) et Foiben-Taontsarintanin'i Madagascar (FTM).

Gautier, L. \& Goodman, S. (2009). Introduction à la flore. In: Goodman, S. (ed.): Paysages naturels et biodiversité de Madagascar. Muséum National d'Histoire Naturelle, Publications scientifiques du Muséum, Paris, pp. 103-139.

Goodman, S. (2009). Paysages naturels et biodiversité de Madagascar. Muséum National d'Histoire Naturelle, Publications scientifiques du Muséum, Paris, 694 pp.

GotTsche, C.M., Lindenberg, J.B. \& Nees von Esenbeck, C. (1844). Synopsis Hepaticarum: coniunctis studiis scripserunt et edi curaverunt. Hamburgi: Meissnerianis, 834 pp.

Grolle, R. (1995). The Hepaticae and Anthocerotae of the East African Islands, An annotated catalogue. Bryophytorum Bibliotheca 48: 1-178.

Griffith, W. (1849). Icones Plantarum Asiaticarum on the Higher Cryptogamous Plants (part 2) Calcutta, $192 \mathrm{pp}$.

Humbert, H. \& Cours-DAme, G. (1965). Carte internationale du tapis végétal et des conditions écologiques. 3 coupures à 1/1000000 de Madagascar. Travaux de section Scientifique et Technique de l'Institut Français de Pondichery, hors-série 6.

JonEs, E.W. (1952). African hepatics. I. The genus Cyathodium in Africa. Transactions of the British Bryological Society 2(1): 55-61. 
Jones, E.W. (1957). African Hepatics. XIII. The Ricciaceae in Tropical Africa. Transactions of the British Bryological Society 3(2): 208-227.

Jones, E.W. \& Pócs, T. (1987). African Hepatics. XXXVI. Three new species of Colura. Journal of Bryology 14: 495-501.

Jovet-Ast, S. (1948). Les hépatiques de Madagascar. Mémoires de l'institut scientifique de Madagascar. Série B. 1: 39-42.

Jovet-Ast, S. (1955). Riccia atromarginata Lev. et sa variété glabra Lev. au Maroc. Revue bryologique et lichénologique 24: 240-247.

Jovet-Ast, S. (1964). Riccia crystallina L. emend Raddi et Riccia cavernosa Hoffm. emend Raddi. (Note préliminaire). Revue bryologique et lichénologique 33: 459483.

Jovet-Ast, S. (1966). Riccia crystallina L. emend Raddi et Riccia cavernosa Hoffm. emend Raddi. Revue bryologique et lichénologique 34: 82-90.

Jovet-AST, S. (1970). Cyathodium africanum Mitt. au Yémen et en Afrique. Revue bryologique et lichénologique 37(1) 57-62.

Jovet-Ast, S. (1986). Les Riccia de la région méditerrannéenne. Cryptogamie Bryologie Lichénologie 7(3): 287-430.

Jovet-Ast, S. (1989). Un complexe de taxons dans le genre Riccia. Cryptogamie Bryologie Lichénologie 10: 95-117.

Jovet-Ast, S. \& Zigliara, M. (1966). La paroi des spores de Targionia lorbeeriana et de Targionia hypophylla: sa valeur taxinomique. Revue bryologique et lichénologique 34: 816-821.

Kürschner, H. (2000). Bryophyte flora of the Arabian Peninsula and Socotra. Bryophytorum Bibliotheca 55: 1-130.

LiNDENBERG, J. (1838). Monographie der Riccieen 84 (1836). Natur-geschichte der europäischen Lebermoose, $440 \mathrm{pp}$.

LoNG, D.G. (2006). Revision of the genus Asterella P. Beauv. in Eurasia. Bryophytorum Bibliotheca 63: 1-299.

LONG, D.G. (2005). Studies on the genus Asterella (Aytoniaceae) VI: infrageneric classification in Asterella. Journal of the Hattori Botanical Laboratory 97: 249261.

LonG, D.G. (2001 [2000]). Studies on the genus Asterella (Aytoniaceae). V. Miscellaneous notes on Asiatic Asterella. Lindbergia 26: 43-45.

M.B.G. (2008). Complexe forestier Makirovana-Tsihomanaomby. Rapport de Présentation du site.

MANJU, C.N., Rajesh, K.P. \& PrakashKumar, R. (2012). On the identity of Riccia fluitans (Ricciaceae: Marchantiophyta) in India. Acta Biologica Plantarum Agriensis 2: 115-124.

Marline, L., Andriamiarisoa, R., Bardat J., Chuah-Petiot, M., Hedderson, T., Reeb, C., Strasberg, D., Wilding, N. \& Ah-Peng, C. (2012). Checklist of the bryophytes of Madagascar. Cryptogamie Bryologie 3: 199-255. https://doi.org/10.7872/cryb.v33.iss3.2012.199

Mitten, W. (1887). The Mosses and Hepaticae collected in Central Africa by the late right Rev. James Hannington, Bishop of Mombasa F.L.S, F.G.S. \& c. with some others including those gathered by Mr H.H. Johnson on Kilimanjaro. Journal of the Linnean Society 32: 298-327.

MoAт, J. \& Sмітн, P. (eds.) (2007). Atlas of the Vegetation of Madagascar. Kew Publishing, $124 \mathrm{pp}$. 
Myers, N., Mittermeier, R.A., Mittermeier, C.G., Gustavo, A.B., DA Fonseca, G. \& Kent, J. (2000). Biodiversity hotspots for conservation priorities. Nature 403: 853-858. https://doi.org/10.1038/35002501

PEARSON, W. (1891a). Frullaniae madagascarienses precipue e collectione Borgeni. Forhandlinger i Videnskabs-selskabet i Christiania 2: 1-9.

PEARSON, W. (1891b). Lejeuneae madagascarienses precipue e collectione Borgeni. Forhandlinger i Videnskabs-selskabet i Christiania 8: 1-9.

PEARSON, W. (1893). Hepaticae Madagascariensis. Notes on a collection made by Rev. Borgchgrevink and Rev. Dahle; 1877-1882. Forhandlinger i Videnskabs-selskabet i Christiania 14: 1-11.

Perold, S.M. (1999). Flora of Southern Africa, Hepatophyta. Part 1: Marchantiopsida, Fascicle 1: Marchantiidae. In: LEISTNER, O.A. (ed.): National Botanical Institute Pretoria. $252 \mathrm{pp}$.

Perold, S.M. (1990). Studies in the genus Riccia (Marchantiales) from Southern Africa. 19. Two new species: R. pulveracea, section Pilifer [sic], and R. bicolorata, section Riccia, group 'Squamatae'. Bothalia 20: 185-190.

Perold, S.M. (1993). Studies in Marchantiales (Hepaticae) from Southern Africa. 1. The genus Dumortiera and D. hirsuta; the genus Lunularia and L. cruciata. Bothalia 23: 49-57.

Perold, S.M. (1995a). Studies in Marchantiales (Hepaticae) from Southern Africa. 8. The genus Plagiochasma, Aytoniaceae. Bothalia 25(1): 13-29.

Perold, S.M. (1995b). A survey of the Ricciaceae of tropical Africa. Fragmenta Floristica et Geobotanica 40: 53-91.

Perold, S. (1995c). Studies in Marchantiales (Hepaticae) from Southern Africa. 9. The genus Marchantia and its five local species. Bothalia 25: 183-204.

Perrier de la Bathie, H. (1921). La végétation malgache. Annales de l'Institut botanico-géologique colonial de Marseille 3(9): 1-226.

Pócs, T. (1995). East African Bryophytes, XIV. Hepaticae from the Indian Ocean Islands. Fragmenta Floristica et Geobotanica 40: 251-277.

Pócs, T. (2001). East African Bryophytes, XVI. New taxa of Lejeuneoideae (Lejeuneaceae) collected in Manongarivo Special Reserve, NW Madagascar. Candollea 56: 69-78.

Pócs, T. (2006). East African Bryophytes. XXI. Two new species of Telaranea, sect. Tenuifoliae and records on Amazoopsis from the Indian Ocean Islands. Acta Botanica Hungarica 48: (1-2): 105-124. https://doi.org/10.1556/ABot.48.2006.1-2.14

Pócs, T. \& GeIsSLER, P. (2002). The bryophytes collected in the Réserve Spéciale de Manongarivo, Madagascar. In: GAUTIER, L. \& Goodman, S.M. (eds.): Inventaire floristique et faunistique de la Réserve Spéciale de Manongarivo (NW Madagascar). Boissiera 59: 41-76.

Pócs, T., MÜller F. \& SHEvock, R. (2015). Additions to the liverwort and hornwort flora of São Tomé and Príncipe II, with Neurolejeunea, a genus new to Africa. Herzogia 28: 50-69. https://doi.org/10.13158/heia.28.1.2015.50

Pócs, T. \& SchäFER-VerwimP, A. (2006). East African Bryophytes, XXIII. Three new species of Diplasiolejeunea (Lejeuneaceae, Jungermanniopsida) from Madagascar. Cryptogamie Bryologie 27(4): 439-452.

Pócs, T. \& VÁŇA, J. (2015). East African Bryophytes XXX. New liverwort and hornwort records. Acta Biologica Plantarum Agriensis 3: 3-21. 
RAUH, W. \& BuChlOH, G. (1961). Riccia atromarginata Levier var. jovet-astii var. nov. Revue bryologique lichénologique 30: 74-79.

Reeb, C., Ranarijaona H.L. \& Dubuisson, J.-Y. (2012). Ecological survey of the Lycophytes and Ferns of the Vohimana Reserve, Madagascar. Plant Ecology and Evolution 145: 410-418. http://dx.doi.org/10.5091/plecevo.2012.516

Renauld, F. (1897). Prodrome de la flore bryologique de Madagascar, des Mascareignes et des Comores. Monaco: Impr., de Monaco, 316 pp.

RENAUlD, F. (1909). Essai sur les Leucoloma de Madagascar et supplément au prodrome de la flore bryologique de Madagascar des Mascareignes et des Comores. In: Mémoires et documents, Par Ordre de S. A. S. le Prince Albert V Prince Souverain de Monaco.

RENAULD, F. \& CARDOT, J. (1895). CH. 39: Histoire naturelle des plantes mousses. In: Alfred et Guillaume Grandidier (eds.): Histoire physique, naturelle et politique de Madagascar: v. 39.

Schuster, R. M. (1987). Studies on Metzgeriales. I. North American Aneuraceae. Journal of the Hattori Botanical Laboratory 62: 299-329.

Schuster, R. M. (1992). The Hepaticae and Anthocerotae of North America, Vol. VI. Field Museum of Natural History, Chicago.

Söderström, L, Hagborg, A., von Konrat, M., Bartholomew-Began, S., Bell, D., Briscoe, L., Brown, E., Cargill, D.C., da Costa. D.P., Crandall-Stotler, B.J., Cooper, E., Dauphin, G., Engel, J., Feldberg, K., Glenny, D., Gradstein, S.R., He, X., Hentschel, J., Ilkiu-Borges, A.L., Katagiri, T., Konstantinova, N.A., Larraín, J., LonG, D., Nebel, M., Pócs, T., Puche, F., Reiner-Drehwald, E., Renner, M., Sass-Gyarmati, A., SchäFerVerwimp, A., Segarra-Moragues, J., Stotler, R.E., Sukkharak, P., Thiers, B., Uribe, J., VÁŇA, J, WigGinTON, M., ZHANG, L., \& ZHU, R-L. (2016). World checklist of hornworts and liverworts. PhytoKeys 59: 1-828.

http://dx.doi.org/10.3897/phytokeys.59.6261

SRIVASTAVA, S. \& Dixit, R. (1996). The genus Cyathodium Kunze. Journal of the Hattori Botanical Laboratory. 80: 149-215.

Stephani, F. (1891). Hepaticae Africanae. Hedwigia 30: 201-261.

StEPHANI, F. (1892). Hepaticae Africanae. Hedwigia 31: 165-174.

StePhAni, F. (1893). Hepaticae Africana. Hedwigia 32: 10-29.

THÉRIOT, M. (1920). Contribution à la flore bryologique de Madagascar. Le Havre : Imprimerie Micaux frères, $191 \mathrm{pp}$.

TIXIER, P. (1977). Espèces nouvelles malgaches du genre Diplasiolejeunea (Spruce) Schiffn. (Hepaticae). Lindbergia 4: 117-125.

TIXIER, P. (1984). Bryophytes de la région malgache (révision bibliographique depuis 1950). Bulletin Trimestriel de l'association pour l'Avancement de la Recherche Scientifique concernant Madagascar et le Région Malgache 17: 22-36.

Tixier, P. (1992). Deux espèces nouvelles malgaches du genre Calymperopsis (Musci). Bryologist 95: 284-286.

VANDEN BERGHEN, C. (1972). Hépatiques et Anthocérotées. In: Cercle Hydrobiologique de Bruxelles (ed.), Résultats scientifiques. Exploration hydrobiologique du bassin du lac Bangweolo et du Luapula 8: 1-202.

Vanden Berghen, C. (1981). Le genre Plagiochila (Dum.) Dum. (Hepaticae) à Madagascar et aux Mascareignes, principlement d'apres les récoltes de $\mathrm{M}$. Onraedt. Bulletin du Jardin botanique National de Belgique 51(1-2): 41-103.

Vanderpoorten, A., Gradstein, S.R., Carine, M.A. \& Devos, N. (2010). The ghosts of 
Gondwana and Laurasia in modern liverwort distributions. Biological Reviews 85: 471-487. http://dx.doi.org/10.1111/j.1469-185X.2009.00111.x

Wendenbaum, E M. (2011). Makay, à la découverte du dernier Eden. La Martinière, $173 \mathrm{pp}$.

White, F. (2002). Vegetation Map of Africa. [Carte de Vegetation de l'Afrique]. UNESCO / AETFAT / UNSO.

Wigginton, M.J. (ed.), (2004). E.W. Jones's liverwort and hornwort Flora of West Africa. Scripta Botanica Belgica, National Botanic Garden of Belgium, $444 \mathrm{pp}$.

WigGinTon, M.J. (2009). Checklist and distribution of the liverworts and hornworts of sub-Saharan Africa, including the East African Islands. Tropical Bryology Research Reports 8: 1-116.

Zamora, P.G., Ros, R.M. \& Guerra, J. (1990). Taxonomía numérica en Targionia L. (Hepática). Anales del Jardin Botanico de Madrid 46: 393-404.

(submitted: 12.11.2017, accepted: 02.02.2018) 